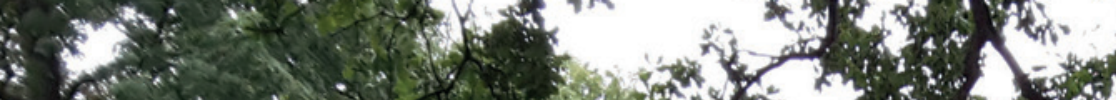

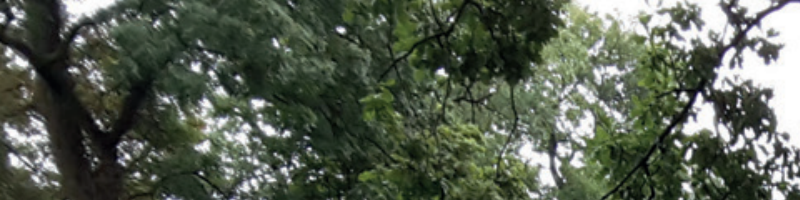
5

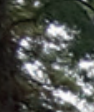

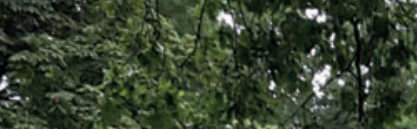
(1)

$\frac{5}{4}$
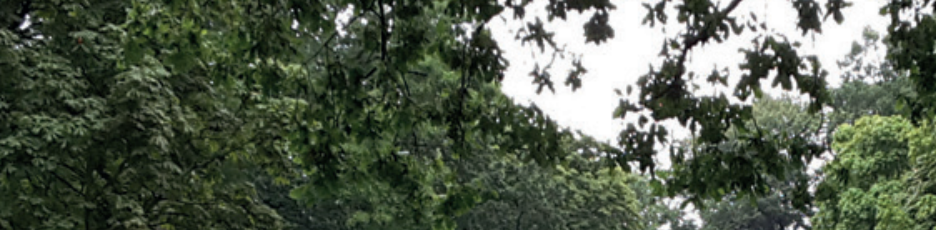

$7^{7}+4+21-3$

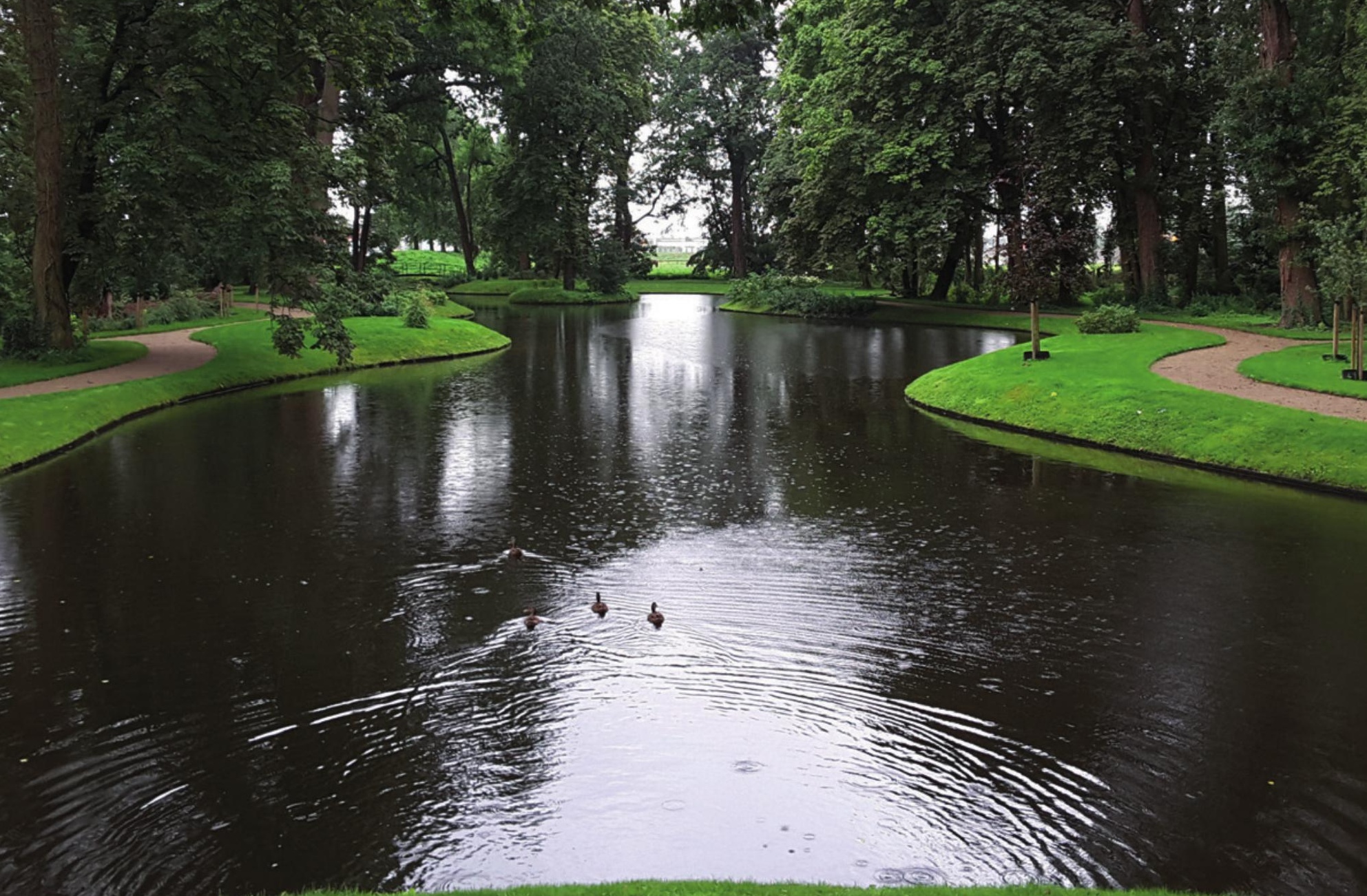

\section{Onderhoudsstaat en onderhoudskosten van groen erfgoed in Nederland}

Maurice Paulissen, Patricia Debie, Dick Brus, Arjan Koomen, Wim Nieuwenhuizen, Rini Schuiling, Paul Verkuijl 



\section{Onderhoudsstaat en onderhoudskosten van groen erfgoed in Nederland}

Maurice Paulissen ${ }^{1}$, Patricia Debie ${ }^{2}$, Dick Brus $^{1}$, Arjan Koomen $^{1}$, Wim Nieuwenhuizen ${ }^{1}$, Rini Schuiling ${ }^{1}$, Paul Verkuijl $^{2}$

1 Wageningen Environmental Research (Alterra)

2 Debie \& Verkuijl tuin- en landschapsarchitectuur

Dit onderzoek is uitgevoerd in opdracht van de Rijksdienst voor het Cultureel Erfgoed

Wageningen Environmental Research

Wageningen, december 2016

Rapport 2773

ISSN 1566-7197 
Paulissen, M., P. Debie, D. Brus, A. Koomen, W. Nieuwenhuizen, C. Schuiling, P. Verkuijl, 2016. Onderhoudsstaat en onderhoudskosten van groen erfgoed in Nederland. Wageningen, Wageningen Environmental Research, Rapport 2773. 82 blz.; 30 fig.; 26 tab.; 20 ref.

In opdracht van de Rijksdienst voor het Cultureel Erfgoed is onderzoek gedaan naar de onderhoudsstaat en de jaargemiddelde onderhoudskosten van rijksbeschermd groen erfgoed in Nederland. Het onderzoek is uitgevoerd op basis van een steekproef van 209 objecten, verdeeld over 14 categorieën groen erfgoed. De onderhoudsstaat van het groene erfgoed in Nederland is overwegend redelijk (69\% van de objecten); $20 \%$ van de objecten scoort goed en $11 \%$ matig. Het beeld van de onderhoudsstaat varieert tussen individuele typen groenelementen en tussen categorieën groen erfgoed. Uitgaande van sober en doelmatig onderhoud volgens de Leidraad subsidiabele instandhoudingskosten 2013 bedragen de totale onderhoudskosten voor het onderhoud van alle ongeveer 1.400 groene rijksmonumenten in Nederland $€ 132$ miljoen per jaar incl. btw en indirecte kosten. In aanvulling op deze kostenberekening is bij zeven elementtypen afgeweken van de onderhoudsfrequenties volgens de Leidraad omdat deze niet toereikend worden geacht voor sober en doelmatig onderhoud. De totale onderhoudskosten bedragen dan $€ 185$ miljoen per jaar. Het rapport sluit af met conclusies en aanbevelingen.

Trefwoorden: groen erfgoed, rijksmonumenten, onderhoudsstaat, onderhoudskosten, Sim (Subsidieregeling instandhouding monumenten), beschermde groenaanleg, monitoring, steekproef

Dit rapport is gratis te downloaden van http://dx.doi.org/10.18174/401507 of op www.wur.nl/environmental-research (ga naar 'Wageningen Environmental Research' in de grijze balk onderaan). Wageningen Environmental Research verstrekt geen gedrukte exemplaren van rapporten.

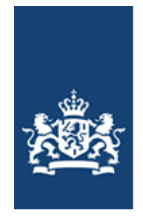

Rijksdienst voor het Cultureel Erfgoed

Ministerie van Onderwijs, Cultuur en

Wetenschap

(c) 2016 Rijksdienst voor het Cultureel Erfgoed.

- Overname, verveelvoudiging of openbaarmaking van deze uitgave is toegestaan mits met duidelijke bronvermelding.

- Overname, verveelvoudiging of openbaarmaking is niet toegestaan voor commerciële doeleinden en/of geldelijk gewin.

- Overname, verveelvoudiging of openbaarmaking is niet toegestaan voor die gedeelten van deze uitgave waarvan duidelijk is dat de auteursrechten liggen bij derden en/of zijn voorbehouden.

Wageningen Environmental Research aanvaardt geen aansprakelijkheid voor eventuele schade voortvloeiend uit het gebruik van de resultaten van dit onderzoek of de toepassing van de adviezen.

Wageningen Environmental Research Rapport 2773 | ISSN 1566-7197

Foto omslag: buitenplaats Vredenoord, Den Haag. Foto: Debie \& Verkuijl, 2016 


\section{Inhoud}

$\begin{array}{ll}\text { Woord vooraf } & 5\end{array}$

$\begin{array}{ll}\text { Samenvatting } & 7\end{array}$

$1 \quad$ Inleiding

11

$1.1 \quad$ Achtergrond en doelstelling $\quad 11$

1.2 Vraagstelling en afbakening 11

1.2.1 Vraagstelling 11

$\begin{array}{ll}1.2 .2 \text { Afbakening } & 12\end{array}$

$\begin{array}{lll}1.3 & \text { Leeswijzer } & 13\end{array}$

$\begin{array}{ll}\text { Beleid: overzicht en ontwikkeling } & 14\end{array}$

2.1 Groen erfgoed 14

2.2 Wet- en regelgeving 14

$\begin{array}{ll}2.3 \text { Beleidsdoelen en instrumenten } & 15\end{array}$

2.3.1 Waarderen van groen erfgoed $\quad 15$

2.3.2 Bevorderen van kennisontwikkeling $\quad 15$

2.3.3 Regelen van bescherming 16

2.3.4 Toekennen van subsidie $\quad 17$

2.3.5 Conclusie beleidsdoelen en instrumenten 19

2.4 Externe invloeden op onderhoud en onderhoudsstaat $\quad 19$

$\begin{array}{lr}\text { Gevolgde methode } & \mathbf{2 0}\end{array}$

3.1 Inventarisatie en categorisering groen erfgoed $\quad 20$

$\begin{array}{lll}3.2 & \text { Steekproef } & 20\end{array}$

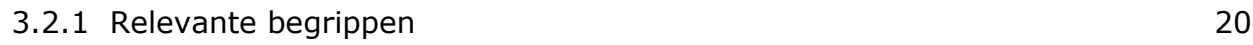

3.2.2 Samenstelling door RCE aangeleverde steekproef $\quad 22$

3.2.3 Aanpassing steekproef op basis van respons eigenaren $\quad 22$

$\begin{array}{lll}3.3 & \text { Voorbereiding voor de veldinventarisatie } & 23\end{array}$

3.3.1 Begrenzen van de objecten in de steekproef 23

$\begin{array}{ll}\text { 3.3.2 Opmaken basiskaarten per object } & 23\end{array}$

3.3.3 Op maat maken en testen Collector-app $\quad 24$

3.3.4 Opstellen beeldkwaliteitsdocument $\quad 24$

$\begin{array}{lll}3.4 & \text { Veldinventarisatie } & 25\end{array}$

3.5 Analyse van de verzamelde gegevens $\quad 26$

3.5.1 Gegevensvoorbewerking $\quad 26$

3.5.2 Berekening onderhoudsstaat per elementtype en per object 26

3.5.3 Kostenberekening onderhoud groenaanleg 26

$\begin{array}{ll}3.5 .4 \text { Categorisering van eigenaren } & 27\end{array}$

3.5.5 Uitgesloten of ontbrekende onderdelen $\quad 27$

3.6 Extrapolatie van steekproef naar heel Nederland 28

3.6.1 Extrapolatie resultaten onderhoudsstaat $\quad 28$

3.6.2 Extrapolatie resultaten onderhoudskosten 28

3.6.3 Extrapolatie onderhoudskosten per landsdeel 28

$\begin{array}{ll}3.6 .4 & \text { Bepalingsfouten } \\ & 29\end{array}$ 
4.1 Resultaten op steekproefniveau 30

4.1.1 Verschillen tussen categorieën groen erfgoed 30

4.1.2 Verschillen tussen categorieën eigenaren 31

4.1.3 Verschillen tussen provincies 31

4.1.4 Verdeling scores onderhoudsstaat geïnventariseerde elementen $\quad 32$

4.1.5 Verschillen tussen elementtypen $\quad 32$

4.1.6 Tot besluit $\quad 32$

4.2 Extrapolatie van steekproef naar heel Nederland $\quad 34$

$\begin{array}{ll}\text { Onderhoudskosten groen erfgoed } & 36\end{array}$

5.1 Resultaten op steekproefniveau 36

5.1.1 Verschillen tussen categorieën groen erfgoed 36

5.1.2 Verschillen tussen categorieën eigenaren 37

$\begin{array}{ll}5.1 .3 \text { Verschillen tussen provincies } & 39\end{array}$

5.1.4 Verschillen tussen elementtypen $\quad 41$

5.1.5 Onderhoudskosten bij afwijkende onderhoudsfrequenties $\quad 42$

5.1.6 Onderscheid tussen prioriteit 1 en $2 \quad 42$

5.1.7 Onderhoudskosten vergeleken met onderhoudsstaat $\quad 43$

5.1.8 Schatting onderhoudskosten elementtypen niet in RCE-
standaardbegrotingsmodel

$\begin{array}{lll}5.2 & \text { Extrapolatie van steekproef naar heel Nederland } & 48\end{array}$

6.1 Afwijkingen van de omschrijvingen van de rijksmonumenten 51

6.2 Veldimpressie onderhoudsstaat objecten 51

6.2.1 Vergelijking twee methoden onderhoudsstaat op objectniveau $\quad 51$

6.2.2 Foto-impressie contrasten onderhoudsstaat $\quad 52$

$\begin{array}{lll}6.3 & \text { Informatielacunes bij eigenaren } & 58\end{array}$

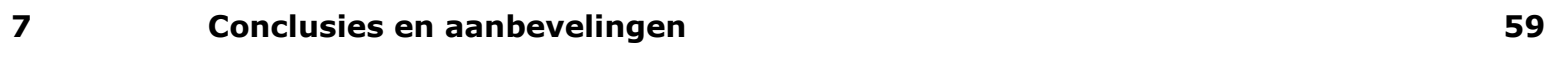

$\begin{array}{lll}7.1 & \text { Conclusies } & 60\end{array}$

$\begin{array}{lll}7.2 & \text { Aanbevelingen } & 62\end{array}$

$\begin{array}{ll}\text { Literatuur } & 63\end{array}$

$\begin{array}{lll}\text { Bijlage } 1 & \text { Begrippenlijst } & 64\end{array}$

Bijlage 2 Prioriteit en afwijkende onderhoudsfrequentie per elementtype 67

Bijlage 3 Toelichting kostenberekening onderhoud groenaanleg $\quad 70$

Bijlage 4 Onderhoudsstaat per categorie groen erfgoed, eigenaar en $\begin{array}{ll}\text { provincie } & 75\end{array}$

Bijlage 5 Onderhoudskosten naar prioriteit en onderhoudsfrequentie $\quad 77$

$\begin{array}{lll}\text { Bijlage } 6 & \begin{array}{l}\text { Schatting onderhoudskosten elementtypen niet in RCE- } \\ \text { standaardbegrotingsmodel }\end{array}\end{array}$

Bijlage 7 Waargenomen afwijkingen van de omschrijving van het rijksmonument 


\section{Woord vooraf}

Naast de auteurs werkten namens het uitvoerende consortium aan dit project mee:

Erwin van den Berg, Jan Clement, Josine Donders, Gert van Dorland, Anja de Jong,

Christina Kallimani, Samantha Krawczyk, Han Naeff, Gijs Peters, Igor Staritsky, Corine Tak, Simon Veen, Mark ten Vregelaar, Ruut Wegman, Joris Wever en Marieke Wolters (Wageningen Environmental Research) en Jan Holwerda, Anne van Schaijk, Jaap-Dirk Tump en Willemijn Zwikstra (Debie \& Verkuijl).

Het onderzoek is begeleid door een klankbordgroep waarin de volgende personen en organisaties zitting hebben gehad:

Federatie Instandhouding Monumenten:

Fennema Advies:

Geldersch Landschap \& Kasteelen:

Landelijke Organisatie van Begraafplaatsen:

Vereniging Het Gilde van Tuinbazen:

Vereniging Particuliere Historische Buitenplaatsen:

Vereniging Stadswerk:
Nel Viersen

Age Fennema

Ciska van der Genugten

Wim van Midwoud

Henk Boers

Erik Greve, Egbert ten Cate

Annet Doesburg

We willen alle leden van de klankbordgroep danken voor hun kritische en constructieve inbreng gedurende de looptijd van dit project.

Ten slotte een woord van dank voor de opdrachtgever RCE en in het bijzonder Robert Berkovits, Hans-Lars Boetes, Natascha Lensvelt, Nanette de Jong, Antoinette Le Coultre, Iris Contant en Dorothée Koper-Mosterd voor hun betrokkenheid en meedenken gedurende het project. 


\section{Samenvatting}

De minister van Onderwijs, Cultuur en Wetenschap heeft de Tweede Kamer toegezegd een onderzoek te laten uitvoeren naar de onderhoudsstaat en instandhoudingsbehoefte van rijksmonumenten in Nederland die bestaan uit een beschermde groenaanleg. Voorbeelden hiervan zijn tuinen, parken, begraafplaatsen, de groenaanleg van fabrieksterreinen en boerenerven. Voorliggend rapport is het resultaat van dit onderzoek.

Voor dit onderzoek is de instandhoudingsbehoefte beperkt tot het in beeld brengen van de onderhoudskosten om de groenaanleg door middel van sober en doelmatig onderhoud in een redelijke staat te houden. De restauratiebehoefte is niet in kaart gebracht. Met sober en doelmatig wordt bedoeld dat het onderhoud plaatsvindt volgens de normen van de Leidraad subsidiabele instandhoudingskosten 2013 (hierna: Leidraad). In dit onderzoek is geen rekening gehouden met het historische referentiebeeld van de onderzochte groene monumenten.

De centrale vraagstelling van deze studie betreft dus de onderhoudsstaat en de onderhoudskosten van rijksbeschermd groen erfgoed. Een aanvullende onderzoeksvraag is: komt de omschrijving van het rijksmonument (hierna: de omschrijving) ${ }^{1}$ overeen met de aangetroffen groenaanleg? Zo nee, hoe wijkt de waargenomen situatie af van de omschrijving?

Om deze vragen te kunnen beantwoorden, is uit de totale populatie van ongeveer 1.400 groene rijksmonumenten een steekproef getrokken van 209 objecten (zie onderstaande tabel). Deze 209 objecten zijn in het veld met behulp van een GIS-app (geografisch informatie systeem) geïnventariseerd. Hierdoor zijn alle data direct ruimtelijk en digitaal vastgelegd. Binnen elk geïnventariseerd object zijn de globale afmetingen van de aanwezige groenelementen opgenomen. Ook is de onderhoudsstaat van de aanwezige elementen met behulp van een beeldkwaliteitsdocument op een gestandaardiseerde en herhaalbare manier beoordeeld. Daarbij zijn vier klassen onderscheiden: goed, redelijk, matig en slecht.

Aantal objecten per categorie groen erfgoed dat is opgenomen in het monumentenregister en in de steekproef voor dit onderzoek.

\begin{tabular}{|c|c|c|}
\hline Categorie & Monumentenregister & Steekproef \\
\hline Groenaanleg bij buitenplaatsen \& landgoederen & 569 & 85 \\
\hline Begraafplaatsen & 255 & 38 \\
\hline Boerentuinen en boerenerven & 73 & 11 \\
\hline Stadsparken en plantsoenen & 67 & 10 \\
\hline Stadstuinen & 55 & 8 \\
\hline Groenaanleg bij medische en sociale instellingen & 48 & 7 \\
\hline Tuinen en parken bij landhuizen & 40 & 6 \\
\hline Erven & 32 & 5 \\
\hline Collectietuinen & 9 & 2 \\
\hline Totaal & 1.391 & 209 \\
\hline
\end{tabular}

\footnotetext{
1 Vóór de inwerkingtreding van de Erfgoedwet 2016 werd hiervoor het begrip registeromschrijving gebruikt.
} 
De onderhoudsstaat is niet alleen op het niveau van de groenelementen vastgesteld, maar ook op objectniveau. Daartoe is de modale waarde berekend van de scores van de afzonderlijke elementen binnen het object. Als alternatieve methode is bij de bezochte objecten de onderhoudsstaat van het object als geheel direct visueel door de veldonderzoeker geschat na afloop van het veldwerk.

De berekening van de onderhoudskosten voor de diverse groenelementen heeft als basis het RCEstandaardbegrotingsmodel groen, versie 8-9-2015. Bij de kostenberekening is gebruikgemaakt van tijd- en kostennormen uit de Leidraad. Op basis hiervan zijn de diverse elementtypen ingedeeld in prioriteit 1 (hoofdstructuur en kernwaarden van het groene monument) en prioriteit 2 (niet subsidiabel vanuit de Subsidieregeling instandhouding monumenten, Sim). Daarnaast zijn in deze studie elementen onderscheiden die niet onder prioriteit 1 of 2 vallen, omdat ze niet worden gesubsidieerd, maar wel tot het groen erfgoed behoren. Denk hierbij bijvoorbeeld aan bouwland, natuur- of productiebos. In de veldinventarisatie zijn de omvang en de onderhoudsstaat van deze elementtypen niet opgenomen. Ook zijn deze elementtypen niet meegenomen in de berekening van de onderhoudskosten. Wanneer het door bij het onderzoek betrokken deskundigen nodig werd geacht om voor sober en doelmatig onderhoud af te wijken van de onderhoudsfrequenties zoals omschreven in de Leidraad, zijn de aanvullende kosten hiervan afzonderlijk in beeld gebracht.

Van alle geïnventariseerde groenelementen is $26 \%$ in een goede staat en $50 \%$ in een redelijke staat, terwijl $21 \%$ matig en $3 \%$ slecht scoort. Ook op objectniveau is de onderhoudsstaat van het groene erfgoed in Nederland overwegend redelijk (69\% van de objecten). Wel varieert het beeld van de onderhoudsstaat tussen individuele typen groenelementen en tussen categorieën groen erfgoed. Bij de groenaanleg bij medische en sociale instellingen, bij stadstuinen en bij villatuinen valt minstens de helft van de objecten in de categorie goed. Aan de andere kant is bij pastorietuinen, tuinen bij parken en landhuizen en tuinen bij bedrijven, overheden en organisaties sprake van een aanzienlijk aantal objecten met de onderhoudsstaat matig (respectievelijk 50\%, 33\% en 25\%).

Wat betreft de onderhoudsstaat op objectniveau valt op dat de verdeling van de scores over de vier klassen gelijkmatiger is bij de veldschatting (34\% van de objecten goed, 35\% redelijk, 25\% matig, 6\% slecht) dan bij de uit de elementscores berekende modale waarde (20\% goed, 69\% redelijk, $11 \%$ matig). De beste van de twee methoden is de berekening van de modale onderhoudsstaat op basis van de staat van de aanwezige elementen. Bij deze methode bestaat niet het risico dat de onderhoudsstaat van bepaalde elementtypen onbewust zwaarder of minder zwaar wordt meegewogen in het oordeel. Ook past deze methode beter bij het doel van een gestandaardiseerde, objectieve en herhaalbare aanpak.

Bij elkaar opgeteld bedragen de jaargemiddelde onderhoudskosten voor alle in de steekproef onderzochte objecten $€$ 19.761.486. Bijna de helft van de objecten in de steekproef is in particuliere handen, waardoor deze categorie de hoogste totale onderhoudskosten heeft. Wat betreft de jaarlijkse totale kosten komen de terreinbeherende organisaties - eigenaar van $11 \%$ van de onderzochte objecten - op de tweede plaats. Dit kan worden verklaard door de gemiddelde kosten per object, die bij de terreinbeherende organisaties veel hoger zijn dan bij de overige categorieën eigenaar. In verhouding tot andere categorieën eigenaren beheren de terreinbeherende organisaties relatief grote objecten. Naast de omvang van de objecten is voor de onderhoudskosten overigens medebepalend welke elementtypen in een object aanwezig zijn.

Op basis van de steekproef zijn de jaarlijkse onderhoudskosten voor rijksbeschermd groen erfgoed het hoogst in Gelderland, Utrecht en Noord-Holland. Deze provincies herbergen samen $41 \%$ van alle objecten in de steekproef. Maar ook als we de onderhoudskosten uitdrukken per object, staan deze drie provincies bovenaan qua kosten. Dit komt doordat de twee categorieën groen erfgoed die in onderhoud het duurst zijn in deze drie provincies oververtegenwoordigd zijn: de helft van de stadsparken en plantsoenen en meer dan de helft van de buitenplaatsen en landgoederen uit de steekproef liggen in Gelderland, Utrecht en Noord-Holland.

Als de onderhoudsstaat en onderhoudskosten op objectniveau met elkaar in verband worden gebracht, blijkt er een tendens te zijn dat objecten in een gemiddeld slechtere staat duurder zijn in de totale onderhoudskosten. Dit komt mogelijk doordat deze objecten groter zijn en niet doordat in deze objecten meer elementtypen met hoge onderhoudskosten per hectare aanwezig zijn. Juist objecten die per 
eenheid oppervlakte relatief hoge onderhoudskosten vragen, verkeren in een goede onderhoudsstaat. Omdat de daadwerkelijk gemaakte onderhoudskosten en de beweegredenen van eigenaren niet zijn onderzocht, is een verklaring voor dit patroon moeilijk te geven.

De elementtypen bloemperken, hakhout, houtwal en houtsingel, moestuin, parkbos, stinzenplanten in bos(randen) en bermen, en stinzenweide zijn meegenomen in de veldinventarisatie. Ze zijn echter om budgettaire redenen niet in de Leidraad als subsidiabel aangemerkt en niet in de gestandaardiseerde kostenberekening opgenomen. Voor deze elementtypen is op basis van $\mathrm{SNL}^{2}$ (2016) en deskundigenoordeel een aanvullende schatting gemaakt van de onderhoudskosten (zie bladzijde 47). Ze dragen immers onmiskenbaar bij aan de waarde van het monument.

Van de 209 bezochte objecten werd in 44\% van de gevallen een afwijking geconstateerd van de aangetroffen situatie ten opzichte van de omschrijving van het rijksmonument. Bij de afwijkingen was bij $77 \%$ van de objecten sprake van een ontbrekende beschrijving van de aanlegstijl. Bij $30 \%$ van de objecten was sprake van verdwenen of aangetaste groenelementen. Hierbij wordt aangetekend dat de omschrijvingen vaak enkele decennia geleden zijn opgesteld en daardoor geen actueel beeld kunnen geven. Bovendien zijn ze bedoeld ter identificatie van het beschermde en niet als volledige omschrijving daarvan. Ook verschillen de omschrijvingen van object tot object sterk in omvang en detaillering. Sommige omschrijvingen zijn uitermate summier, andere vrij uitgebreid met veel aandacht voor individuele elementen in de groenaanleg.

De belangrijkste conclusies uit dit onderzoek zijn:

- De onderhoudsstaat van het groene erfgoed in Nederland is overwegend redelijk (69\% van de objecten); $20 \%$ van de objecten scoort goed, $11 \%$ scoort matig en $0 \%$ slecht.

- De totale kosten voor het onderhoud van het rijksbeschermde groene erfgoed in Nederland bedragen $€ 132$ miljoen per jaar. Dit is incl. 38\% indirecte kosten, waaronder btw. Ook is dit uitgaande van sober en doelmatig onderhoud volgens de Leidraad voor zowel Prioriteit 1 als Prioriteit 2.

- Aanvullend is in de kostenberekening bij 7 van de 30 elementtypen afgeweken van de Leidraad. In deze gevallen waren de bij het onderzoek betrokken deskundigen van mening dat de onderhoudsfrequenties volgens de Leidraad niet toereikend zijn voor sober en doelmatig onderhoud. Met deze afwijking bedragen de totale onderhoudskosten van het rijksbeschermde groene erfgoed in Nederland $€ 185$ miljoen per jaar, incl. de indirecte kosten.

- De jaarlijkse onderhoudskosten (incl. indirecte kosten en btw) van elementtypen met prioriteit 2 bedragen $7 \%$ van de totale jaarlijkse onderhoudskosten (prioriteit $1+2$ ), als we ervan uitgaan dat alle potentiële kernwaarde-elementen ook aantoonbaar kernwaarden zijn. Uitgaande van frequenties voor sober en doelmatig onderhoud op basis van deskundigenoordeel van de auteurs (deze frequenties zijn hoger dan die volgens de Leidraad) is dit $5 \%$.

- De geschatte aanvullende jaargemiddelde onderhoudskosten van de elementtypen bloemperken, hakhout, houtwal en houtsingel, moestuin, parkbos, stinzenplanten in bos(randen) en bermen, en stinzenweide bedragen samen $€ 2,8$ miljoen. Dit is $14 \%$ van de totale kosten op steekproefniveau.

- De methodiek voor de inventarisatie van de onderhoudsstaat en onderhoudskosten van groen erfgoed biedt door zijn gestandaardiseerde en herhaalbare opzet (onder meer door gebruik van een beeldkwaliteitsdocument en een app voor de veldinventarisatie) een basis voor toekomstige monitoring van groen erfgoed.

De belangrijkste aanbevelingen zijn:

- Herhaal dit onderzoek periodiek en pas dit toe op alle groene rijksmonumenten. Werk daarbij met een verder geoptimaliseerde aanpak.

- Onderzoek oorzaken en oplossingsrichtingen voor slechter scorende categorieën groen erfgoed.

- Verricht nader onderzoek naar de relatie tussen onderhoudsstaat en onderhoudskosten en betrek daarbij het historische referentiebeeld van de groenaanleg in de inventarisatie.

- Verhoog bij zeven elementtypen de normfrequentie voor sober en doelmatig onderhoud.

- Maak voor de groene rijksmonumenten een uitgebreidere omschrijving (als kennisdeel bij het register).

- Breng de restauratiebehoefte van het rijksbeschermde groene erfgoed in kaart.

- Breng de omvang van externe effecten op onderhoudsstaat en onderhoudskosten beter in beeld.

\footnotetext{
2 Subsidiestelsel Natuur en Landschap.
} 


\section{$1 \quad$ Inleiding}

\subsection{Achtergrond en doelstelling}

De Erfgoedwet 2016, en voorheen de Monumentenwet 1988, beschrijft de bescherming als rijksmonument van door de mens vervaardigde zaken zoals gebouwd erfgoed en groen erfgoed. Onder groen erfgoed verstaan we alle historisch waardevolle aangelegde groene monumenten zoals tuinen, parken, begraafplaatsen, de groenaanleg van fabrieksterreinen en boerenerven. De beschermde groenaanleg bestaat veelal uit een combinatie van harde structuren, zoals paden, waterlopen en reliëf, maar ook uit groene structuren die door de mens zijn aangebracht en gerangschikt: elementen zoals laanbeplanting, weide, parkbos, berceaus, taxushagen of solitaire bomen.

Het Rijk wil meer inzicht in de onderhoudsstaat en instandhoudingsbehoefte van rijksmonumenten met een beschermde groenaanleg. De minister van Onderwijs, Cultuur en Wetenschap heeft de Tweede Kamer toegezegd een onderzoek te laten uitvoeren naar de onderhoudsstaat en instandhoudingsbehoefte van rijksmonumenten in Nederland die bestaan uit een beschermde groenaanleg. Voorliggend rapport is het resultaat van deze studie. Onder instandhoudingsbehoefte verstaan we in dit onderzoek de jaargemiddelde kosten om de groenaanleg door middel van sober en doelmatig onderhoud in een redelijke onderhoudsstaat te houden. De restauratiecomponent van de instandhoudingsbehoefte is in deze studie niet beschouwd. Met sober en doelmatig wordt bedoeld dat het onderhoud plaatsvindt volgens de normen van de Leidraad subsidiabele instandhoudingskosten 2013 (hierna ook: Leidraad).

Een vergelijkbaar onderzoek op de schaal van heel Nederland, waarbij alle categorieën groene monumenten worden meegewogen op basis van een vooraf vastgestelde steekproef, is niet eerder uitgevoerd. Eerdere studies (Ruijgrok 2012, Carpentier e.a. 2013, Ruijgrok 2015) hebben zich vooral gericht op onderhoudskosten van een specifieke categorie groen erfgoed: de landgoederen en buitenplaatsen.

Dit onderzoek past in het beleid van het ministerie van Onderwijs, Cultuur en Wetenschap en in de werkzaamheden van de RCE voor de erfgoedmonitor (www.erfgoedmonitor.nl). Vanuit het perspectief van monitoring is het ontwikkelen van een objectieve methodiek die ook in de toekomst kan worden herhaald een voorwaarde voor dit onderzoek. Vergelijkbare onderzoeken zijn uitgevoerd voor het gebouwde en het archeologische erfgoed.

\subsection{Vraagstelling en afbakening}

\subsubsection{Vraagstelling}

De centrale vraag in dit onderzoek is: in welke staat verkeert de als rijksmonument beschermde groenaanleg in Nederland en welk bedrag is nodig voor het onderhoud ervan?

Deze vraag wordt beantwoord op basis van een steekproef van 209 rijksmonumenten met een beschermde groenaanleg. Deelvragen daarbij zijn:

- Wat is de globale omvang van de aanwezige groenelementen?

- Wat is de onderhoudsstaat op element- en objectniveau?

- Wat zijn de onderhoudskosten op element- en objectniveau? 
De onderhoudskosten worden berekend op basis van de onderhoudsfrequenties zoals opgenomen in de Leidraad. Soms is het door de bij het onderzoek betrokken deskundigen nodig geacht om voor sober en doelmatig onderhoud af te wijken van de frequenties volgens de Leidraad. In die gevallen wordt dit afzonderlijk in beeld gebracht.

Bij de onderhoudsstaat en -kosten maken we onderscheid tussen groenelementen met prioriteit 1, prioriteit 2 en elementen zonder prioriteit (zie onderstaand kader). Omwille van de overzichtelijkheid en leesbaarheid zijn de onderzoeksresultaten in de hoofdtekst van dit rapport niet uitgesplitst naar prioriteit. Dit is wel gedaan in een aantal bijlagen bij dit rapport.

Een aanvullende vraag in dit onderzoek is: klopt binnen de omschrijving van het rijksmonument de beschrijving van de groenaanleg? Zo nee, hoe wijkt de waargenomen situatie af van de omschrijving?

De resultaten worden op steekproefniveau ingedeeld naar categorie groen erfgoed, categorie eigenaar, provincie en type groenelement. Voor zover mogelijk en zinvol vanuit de steekproefopzet worden deze indelingen ook toegepast bij de vertaling van de resultaten naar heel Nederland.

De resultaten in deze rapportage worden geanonimiseerd en op geaggregeerd niveau beschreven.

\subsubsection{Afbakening}

Dit rapport gaat over de actuele onderhoudsstaat en geschatte onderhoudskosten van groen erfgoed. Bij het vaststellen van deze onderhoudskosten wordt geen rekening gehouden met eventuele vermindering ervan door regelingen om eigenaren financieel tegemoet te komen in het onderhoud van groen erfgoed, zoals subsidies, fiscale regelingen, regelingen rond btw, leningen en provinciale regelingen. Wat betreft de instandhoudingsbehoefte wordt in dit onderzoek alleen het reguliere onderhoud in bedragen vertaald. De eventuele restauratieopgave wordt niet in euro's vertaald. Wel wordt weergegeven hoeveel monumenten in een slechte of matige onderhoudsstaat verkeren, wat gezien kan worden als een indicatie voor actuele restauratieopgaven. Deze inventarisatie genereert resultaten over de groene elementen die er nu zijn en levert geen informatie over de gewenste aard en staat van de groene elementen vanuit een historisch perspectief, of over sinds de bescherming verdwenen elementen.

\section{Toelichting prioriteiten (1, 2 en 'geen')}

Niet alle voor de instandhouding noodzakelijke kosten kunnen op grond van de Sim (Subsidieregeling instandhouding monumenten) worden gesubsidieerd. Er zijn prioriteiten gesteld. Er is een splitsing aangebracht tussen subsidiabel onderhoud enerzijds en op grond van de Sim niet-subsidiabel onderhoud en restauratie anderzijds. Subsidiabel op grond van de Sim zijn onderhoudswerkzaamheden met 'prioriteit 1 '. Het betreft onderhoudswerkzaamheden aan de hoofdstructuur en de aantoonbare kernwaarden (hoofdkarakteristiek) van groene monumenten. Indien de kernwaarden niet kunnen worden aangetoond, zijn de onderhoudswerkzaamheden niet subsidiabel. In dit onderzoek is er voor de berekening van de onderhoudsbehoefte van uitgegaan dat de onderhoudswerkzaamheden in deze categorie altijd subsidiabel zijn.

Onderhoudswerkzaamheden met 'prioriteit 2 ' en restauratiewerkzaamheden zijn niet subsidiabel op grond van de Sim. Ze kunnen wel subsidiabel zijn in het kader van een andere subsidieregeling, bijvoorbeeld een restauratiesubsidieregeling van een provincie. ${ }^{3}$

Daarnaast zijn in deze studie elementen onderscheiden die niet onder prioriteit 1 of 2 vallen. Denk hierbij aan bouwland en natuur- of productiebos. In de veldinventarisatie zijn de omvang en de onderhoudsstaat van deze elementtypen niet opgenomen. Ook zijn deze elementtypen niet meegenomen in de berekening van de onderhoudskosten.

\footnotetext{
3 Bron: http://cultureelerfgoed.nl/sites/default/files/downloads/dossiers/leidraad_subsidiabele_instandhoudingskosten_2013.pdf.
} 


\subsection{Leeswijzer}

De opzet van dit rapport is als volgt:

In hoofdstuk 2 wordt een overzicht gegeven van de bescherming van rijksbeschermd groen erfgoed en de daarvoor ontwikkelde wet- en regelgeving en beleidsinstrumenten.

Hoofdstuk 3 beschrijft de methodische uitgangspunten en de aanpak die in dit onderzoek is gevolgd. Achtereenvolgens komen aan bod de opzet van de steekproef (paragraaf 3.1), de voorbereiding voor de veldinventarisatie (paragraaf 3.3), de veldinventarisatie zelf (paragraaf 3.4), de analyse van de verzamelde gegevens (paragraaf 3.5 ) en de vertaling van de steekproefresultaten naar alle 1.400 groene rijksmonumenten in Nederland (paragraaf 3.6).

In hoofdstuk 4 worden de bevindingen over de onderhoudsstaat gepresenteerd. Daarbij worden de resultaten op steekproefniveau gepresenteerd naar categorie groen erfgoed, categorie eigenaar, provincie en type groenelement (paragraaf 4.1). Op basis van deze resultaten worden schattingen gegeven voor de onderhoudsstaat van alle rijksmonumenten in Nederland (paragraaf 4.2).

Hoofdstuk 5 heeft een soortgelijke opzet als het vorige hoofdstuk, maar gaat in op de bevindingen voor de onderhoudskosten. Ook hier worden de resultaten eerst besproken en gecategoriseerd op steekproefniveau (paragraaf 5.1) en vervolgens vertaald naar wat dit qua onderhoudskosten betekent voor de hele populatie groene rijksmonumenten in Nederland (paragraaf 5.2).

In hoofdstuk 6 komt een aantal overige bevindingen uit het onderzoek aan bod. In paragraaf 6.1 gaan we in op de belangrijkste typen waargenomen afwijkingen van de omschrijving van de rijksmonumenten. In paragraaf 6.2 vullen we de resultaten uit hoofdstuk 4 (onderhoudsstaat) aan met een beeldimpressie uit de veldinventarisatie.

Ten slotte vatten we in hoofdstuk 7 de conclusies en aanbevelingen uit deze studie samen.

In een zestal bijlagen lichten we de gevolgde aanpak en uitgangspunten verder toe en presenteren we de resultaten uit hoofdstuk 4 (onderhoudsstaat) en 5 (onderhoudskosten) in een verder uitgesplitste vorm. 


\section{Beleid: overzicht en ontwikkeling}

\section{$2.1 \quad$ Groen erfgoed}

Een rijksbeschermde groenaanleg kan bestaan uit bijvoorbeeld een historische tuin, park, buitenplaats, boerenerf, verdedigingswerk, collectietuin of begraafplaats. Deze worden ook wel samengevat onder de term groen erfgoed. Groen erfgoed vormt vaak een prachtige omlijsting voor een huis, boerderij, kerk of klooster. In het verleden was de groenaanleg bovendien van belang voor gezondheid, voedselvoorziening, recreatie of verdediging. Groen erfgoed-objecten getuigen van de door de eeuwen heen veranderde relatie tussen mens en de door hem gecreëerde 'natuur'. Dit komt tot uiting in een ontwerp, in de aanleg en in de toegepaste materialen, zoals verhardingen en beplanting. Groen erfgoed wordt dan ook gezien als ontwerpproduct met een hoofdzakelijk culturele of esthetische doelstelling (RCE 2014). Dit erfgoed is van wetenschappelijke betekenis wat betreft tuinen cultuurhistorie, botanie, horticultuur en archeologie. Door hun ouderdom zijn de groenstructuren een waardevol onderdeel van ons dynamische landschap. Als 'levend' erfgoed is het buitengewoon kwetsbaar en vraagt het regelmatig onderhoud om niet verloren te gaan. De instandhouding van groen erfgoed is van algemeen belang. Om die reden heeft het Rijk wet- en regelgeving ontwikkeld. In dit hoofdstuk wordt daarvan een overzicht gegeven en worden ontwikkelingen geschetst.

\section{$2.2 \quad$ Wet- en regelgeving}

Tijdens de opkomst van de monumentenzorg speelt groen erfgoed aanvankelijk slechts een beperkte rol in de wetgeving. Groen erfgoed staat in eerste instantie vooral ten dienste van gebouwd erfgoed. Ondanks dat de eerste wetgeving (1961) de bescherming van een groene aanleg als monument niet uitsluit, is van deze mogelijkheid maar weinig gebruikgemaakt. Alleen delen van parken worden wettelijk beschermd en dit niet zozeer vanwege hun tuinhistorische waarde, maar vanwege de samenhang met het gebouwde erfgoed. Stadsparken en verdedigingswerken vormen hierop een uitzondering. Na de publicatie Bescherming der Nederlandse Buitenplaatsen (1972) krijgt de rijksoverheid ook aandacht voor behoud en bescherming van de tuinhistorische waarden van buitenplaatsen (RCE 2014).

De bijzondere waarden van monumentaal groen worden door het ministerie van Onderwijs, Cultuur en Wetenschap (OCW) en het ministerie van Infrastructuur \& Milieu (I\&M) erkend en beschermd via de Monumentenwet 1988 en de Wet algemene bepalingen omgevingsrecht (Wabo). Met ingang van 1 juli 2016 is de Monumentenwet 1988 opgegaan in de Erfgoedwet, waarin diverse wettelijke regelingen over het behoud en beheer van het Nederlandse erfgoed zijn geïntegreerd (http://wetten.overheid.nl/zoeken). In de Erfgoedwet is onder meer de instandhoudingsplicht voor eigenaren van rijksmonumenten duidelijker verwoord. De Wabo is de basis voor vergunningverlening in het domein van de fysieke leefomgeving. De omgevingsvergunning integreert alle vergunningen voor bouwen, wonen, monumenten, ruimte, natuur en milieu. Met ingang van 2019 wordt de nieuwe Omgevingswet van kracht waarin regels voor ruimtelijke plannen worden vereenvoudigd en samengevoegd.

De cultuurhistorisch waardevolle samenhang van grotere groene aanlegstructuren kan bedreigd worden door versnippering als gevolg van verkoop, gewijzigd gebruik of ongewenste ingrepen van de eigenaar of beheerder. De Natuurschoonwet 1928 en de Erfgoedwet ontmoedigen deze bedreigingen van planologische aard. Afhankelijk van de mate van openstelling voor publiek voorziet de Natuurschoonwet erin dat het schenkings- en successierecht niet of maar gedeeltelijk wordt ingevorderd en er minder of geen vermogensbelasting is verschuldigd (D'Ancona 1993, Kamerlingh Onnes 1999). 
De bescherming van natuurwaarden, die nadrukkelijk aanwezig kunnen zijn bij groen erfgoed, wordt per 1 januari 2017 opgenomen in de nieuwe Wet natuurbescherming (die sinds 2015 de Boswet, de Natuurbeschermingswet 1998 en de Flora en Faunawet bijeenbrengt;

https://www.eerstekamer.nl/wetsvoorstel/33348_wet_natuurbescherming). De Wet natuurbescherming 2017 geeft provincies de mogelijkheid gebieden gelegen buiten het natuurnetwerk Nederland aan te wijzen die van provinciaal belang zijn vanwege hun natuurwaarden of landschappelijke waarden, met inachtneming van hun cultuurhistorische kenmerken. Deze gebieden worden aangeduid als bijzondere provinciale natuurgebieden, respectievelijk bijzondere provinciale landschappen.

\subsection{Beleidsdoelen en instrumenten}

Met diverse beleidsinstrumenten reguleert de overheid de instandhouding én eventueel noodzakelijke restauraties of onderhoudswerkzaamheden. Een eerste aanspreekpunt voor de eigenaar bij wijziging van een monumentale groenaanleg is de gemeente. Daarnaast spelen Rijk, provincies en gemeenten met hun ruimtelijke instrumentarium een actieve en stimulerende rol bij de bescherming van en de regelgeving rond waardevol groen erfgoed. De Rijksdienst voor het Cultureel Erfgoed (RCE) adviseert, stimuleert, informeert en ondersteunt de diverse betrokken instanties: gemeenten, eigenaren en adviseurs. Samengevat hebben deze partijen vier taken bij het beschermen van groen erfgoed:

1. het waarderen van groen erfgoed;

2. het bevorderen van kennisontwikkeling;

3. het regelen van bescherming;

4. het toekennen van subsidie

(http://cultureelerfgoed.nl/dossiers/groen-erfgoed/waarderen-van-groen-erfgoed).

\subsubsection{Waarderen van groen erfgoed}

Bescherming ofwel instandhouding van groen erfgoed wordt vertaald in behoud, beheer, onderhoud én herstel. Daarvoor zijn richtlijnen opgesteld. Bij beschermde groene rijksmonumenten mag geen tuinrestauratie of reconstructie plaatsvinden zonder gedegen onderzoek, wetenschappelijk verantwoord en afgezet tegen vergelijkbare tuinen. Een belangrijke basis voor deze richtlijnen is gelegd door internationale charters. Het Charter van Venetië (1964) legt de beschermingsstatus van monumenten vast. Groen erfgoed krijgt daarin slechts een summiere beschrijving en bescherming (ICOMOS 1965). In het Charter van Florence (1981) wordt groen erfgoed wel expliciet vermeld (ICOMOS-IFLA 1982). Met de Declaratie van Arnhem (1999) heeft de Nederlandse vertaalslag plaatsgevonden, waarin wordt gepleit voor behoud, beheer en herstel van groen erfgoed (Bomenstichting e.a. 1999). De Richtlijnen voor tuinhistorisch onderzoek en waardering (2012) van de groenaanleg zijn door het Rijk en het werkveld opgesteld. Ze bieden handvatten voor uitvoerders en opdrachtgevers. Dit instrument beschrijft een methodiek om te komen tot een objectieve waardering van de groenaanleg. Door historisch onderzoek worden de beschikbare gegevens geanalyseerd en wordt een basis gelegd voor de beoordeling van ontwikkelingen door gemeenten en adviserende partijen.

\subsubsection{Bevorderen van kennisontwikkeling}

De afgelopen jaren is groen erfgoed als zelfstandige discipline op de kaart gezet (Tabel 1). De rijksoverheid streeft professionalisering en kwaliteitsbevordering na in het hele instandhoudingsproces. Dit doet het Rijk door minder regels voor te schrijven en door het delegeren van taken en verantwoordelijkheden naar decentrale overheden en de markt. In dit proces is de RCE betrokken bij diverse onderwijs- en voorlichtingsinitiatieven. Met het Programma Restauratiekwaliteit stimuleert de RCE vakgroepen om samen met gemeenten, provincies, architecten en eigenaren kwaliteitsrichtlijnen voor instandhouding op te stellen. Ook stimuleert de RCE de onderlinge kennisontwikkeling van de vakgroep leden. De stichting Erkende Restauratiekwaliteit Monumentenzorg (ERM) is in het leven geroepen om branches goede kwalificatieregels te bieden. Zo is het initiatief van de Vereniging van Erfgoedhoveniers (opgericht in 2010) om tot normering en certificering te komen door de RCE ondersteund, waarbij als hulpmiddel voor het onderhoud van het groene erfgoed in 2016 de Uitvoeringsrichtlijn Hovenierswerk historische tuinen en parken (URL) tot stand is gekomen. De Beoordelingsrichtlijn Groen Erfgoed (BRL) reguleert gekwalificeerde bedrijven. Tevens faciliteert de RCE 
kennisuitwisseling door de Vakgroep Groen Erfgoed (opgericht in 2014) voor landschapsarchitecten, adviseurs en onderzoekers.

Met diverse publicaties en kennisplatforms, zoals het Platform Groen Erfgoed, brengt de RCE eigenaren, beheerders, planontwikkelaars, onderzoekers en vakgenoten met elkaar in contact. Onderwijsprogramma's en voorlichting aan andere overheden en erfgoedprofessionals verlopen onder meer via de provinciale steunpunten, de Erfgoedacademie en de Actualiteit \& Ontwikkelingsdagen. Op provinciaal niveau zijn diverse initiatieven uitgewerkt in toegespitste onderwijsprogramma's voor onder andere erfgoedhoveniers of regionale kennisplatforms. Voorbeelden zijn het Platform Utrechtse Buitenplaatsen en het platform Duurzame landgoederen in de provincie Gelderland. Zij organiseren kennisdeeldagen voor eigenaren en beheerders.

De RCE heeft diverse voorlichtingsproducten over groen erfgoed opgesteld voor gemeenteambtenaren, eigenaren, opdrachtgevers en ontwikkelaars. In de brochure Een toekomst voor groen. Handreiking voor de instandhouding van groene monumenten (2012) beantwoordt de RCE veelgestelde vragen die betrekking hebben op de cultuurhistorische waarden van groen erfgoed. De brochure Richtlijnen tuinhistorisch onderzoek. Voor waardestellingen van groen erfgoed (2012) geeft aanbevelingen voor het waarderen van groen erfgoed, beschrijft waaraan een onderzoeksplan moet voldoen en geeft aansprekende voorbeelden en concrete tips. De brochure Eenheid en verscheidenheid, een zoektocht naar een integrale cultuurhistorische waardestelling van het materiële erfgoed (2014) brengt de resultaten van het project De cultuurhistorische waarde van erfgoed, uitgevoerd binnen het kennisprogramma Wat is erfgoed? in beeld. En dit voor meerdere erfgoeddomeinen, waaronder groen erfgoed. Het document schetst een eenduidig waarderingskader dat ook bij groen erfgoed kan worden toegepast.

Tabel 1 Overzicht van de professionalisering van de keten in groen erfgoed.

\begin{tabular}{|c|c|c|}
\hline Wat & Sinds & Voor wie \\
\hline $\begin{array}{l}\text { Richtlijnen Tuinhistorisch onderzoek } \\
\text { http://cultureelerfgoed.nl/publicaties/richtlijnen-tuinhistorisch- } \\
\text { onderzoek-voor-waardestellingen-van-groen-erfgoed }\end{array}$ & 2012 & uitvoerders en opdrachtgevers \\
\hline $\begin{array}{l}\text { Toekomst voor groene monumenten } \\
\text { http://cultureelerfgoed.nl/publicaties/een-toekomst-voor-groen }\end{array}$ & 2012 & $\begin{array}{l}\text { gemeenteambtenaren, eigenaren, } \\
\text { opdrachtgevers en ontwikkelaars }\end{array}$ \\
\hline $\begin{array}{l}\text { Vakgroep Groen Erfgoed } \\
\text { http://vakgroepgroenerfgoed.nl/ }\end{array}$ & 2014 & $\begin{array}{l}\text { landschapsarchitecten, adviseurs en } \\
\text { onderzoekers }\end{array}$ \\
\hline $\begin{array}{l}\text { Beoordelingsrichtlijn Groen Erfgoed (BRL 6000) } \\
\text { http://www.stichtingerm.nl/doc/P013\%20BRL\%20Groen\%20Erf } \\
\text { goed\%20na\%20CCvD\%20(gew\%20161011).pdf }\end{array}$ & 2016 & hoveniers en beheerders \\
\hline
\end{tabular}

\subsubsection{Regelen van bescherming}

De overheid kan met diverse ruimtelijke instrumenten een actieve en stimulerende rol spelen bij het behoud van groen erfgoed. Het Rijksmonumentenregister is daar een van. De RCE heeft de rijksbeschermde groenaanleg in dit register vastgelegd. De samenhang van meerdere beschermde onderdelen wordt met een complexbeschrijving toegelicht (die zelf geen deel uitmaakt van het register) en geeft inzicht in de context waarin het monument tot stand is gekomen. Een groenaanleg kan een eigen monumentnummer hebben of samen met een bijbehorend gebouw beschermd zijn, bijvoorbeeld een kerk met kerkhof of pastorie met tuin (RCE 2012). 
Het beschermingstraject heeft ervoor gezorgd dat tegenwoordig circa 1.400 groene monumenten rijksbeschermd zijn. Naast circa 570 buitenplaatsen en landgoederen zijn er ongeveer 830 objecten in andere categorieën, zoals stads- en volksparken, begraafplaatsen en kerkhoven, pastorie- en kloostertuinen, villatuinen, boerentuinen en -erven, groenaanleg op stedelijke verdedigingswerken, botanische tuinen en tuinen bij woningbouwcomplexen. Bij 350 objecten is groen of erfinrichting met beplanting genoemd. Er zijn naast 88 aanleggen bij religieuze gebouwen en pastorieën ook 255 begraafplaatsen en kerkhoven als rijksmonument aangewezen waarbij de aanleg of groenvoorziening expliciet is beschermd (RCE 2014 en RCE 2016). Via een reguliere instroom is de bescherming van monumenten tot stand gekomen, waarbij ook de categorie historisch groen gewaardeerd en opgenomen is in het Monumentenregister. In het kader van het Programma bescherming historische buitenplaatsen, later Verfijning historische Buitenplaatsen genoemd, is door de RCE de beschrijving van 540 buitenplaatsen verbeterd. Daarbij is soms iets aan de bescherming toegevoegd of weggehaald. Met een landelijk uitgevoerd inventarisatieproject zijn door de RCE ook incidenteel andere categorieën historisch groen gewaardeerd en opgenomen in het Monumentenregister. Dit project is gefaseerd uitgevoerd: Monumenten Inventarisatie (MIP), Monumenten Selectie (MSP) en Monumenten Registratie (MRP) (RCE 2014).

De gemeente is bevoegd gezag voor de Erfgoedwet en kan als vergunningverlener daarnaast via een bestemmingsplan de ruimtelijke kwaliteit van de historische groenaanleg waarborgen en verbetering stimuleren of eisen. Voor vaststelling van een bestemmingsplan dient het Besluit ruimtelijke ordening rekening te houden met aanwezige cultuurhistorische waarden. Planologische kaders voor ontwikkelingen bij kwetsbare historische groenstructuren kunnen een plek krijgen in het gemeentelijk erfgoedbeleid, uitgewerkt in Structuurvisies. Voorgenomen ontwikkelingen, de ruimtelijke hoofdlijnen en de middelen die de gemeente wil inzetten, zijn hierin opgenomen. Bescherming betekent ook het in goede banen leiden van activiteiten waarvoor een omgevingsvergunning nodig is, zoals bouwen, aanleggen, kappen van bomen of verstoren van beschermde planten en dieren. Tevens kan een plaatselijke bomenverordening voor cultuurhistorische afwegingen binnen de bebouwde kom van belang zijn (RCE 2012).

Daarnaast spelen provincies een actieve en stimulerende rol bij landschappelijke ontwikkelingen. Provinciaal beleid op dit vlak wordt vastgelegd in een voor gemeenten bindende Verordening Ruimte. Sommige provincies hebben een landgoederenbiotoop voor bijzondere buitenplaatszones ingesteld, als planningsinstrument om waardevolle structuren zoals zichtlijnen vast te leggen.

\subsubsection{Toekennen van subsidie}

\section{Rijksoverheid}

De overheid hanteert diverse stimuleringsmaatregelen om haar beleidsdoelen te bereiken. Naast fiscale en andere regelingen zijn er subsidies. Programma's voor rijkssubsidies worden vanuit diverse beleidsdepartementen aangestuurd, zoals Onderwijs, Cultuur en Wetenschap (OCW), Financiën (Fin), Economische Zaken (EZ) en Infrastructuur en Milieu (I\&M).

Het ministerie van Onderwijs, Cultuur en Wetenschap (OCW) verleent diverse soorten subsidies aan eigenaren van niet-woonhuisrijksmonumenten. In de jaren tachtig zijn deze subsidie-instrumenten aanvankelijk voor gebouwde monumenten ontwikkeld. Sommige subsidie-instrumenten waren ook deels van toepassing op groene onderdelen. Daarnaast werden subsidie-instrumenten ontwikkeld om achterstallig groot onderhoud op te heffen bij tuinen en parken die van belang waren voor natuurschoon, cultuurhistorie of recreatie. De subsidie-instrumenten zijn gewijzigd na de samenvoeging van onderhoud en restauratie (samen 'instandhouding') en het stimuleren van regulier en planmatig onderhoud voor rijksbeschermde gebouwde monumenten (Donner 2006).

Een van deze onderhoudssubsidies, het Besluit rijkssubsidiering instandhouding monumenten (Brim 2011), nu genaamd Subsidieregeling instandhouding monumenten (Sim) van het ministerie van OCW, heeft de structurele instandhouding van rijksmonumenten op gang gebracht. De Sim stimuleert eigenaren om het onderhoud planmatig voor een periode van zes jaar uit te voeren. De grondslag voor subsidieverlening is sober en doelmatig onderhoud op basis van een instandhoudingsplan. Vanaf 2013 is er een apart subsidiebudget voor groene monumenten ingevoerd. Monumenten die onderdeel 
uitmaken van werelderfgoed (UNESCO) en monumenten die in eigendom zijn van Professionele Organisaties voor Monumentenbehoud (POM's) krijgen sindsdien een voorrangspositie bij de verdeling van subsidie. Voor alle categorieën geldt bovendien dat aanvragen met de laagste begroting als eerste aan bod komen (Zijlstra 2012a en Carpentier e.a. 2013). De aanvrager dient 50\% van de onderhoudskosten van het groene monument waarover subsidie wordt verkregen voor eigen rekening te nemen. Sinds de invoering van de Sim in 2013 is aan 309 groene monumenten subsidie verleend voor in totaal $€ 19,5$ miljoen. In diezelfde periode zijn de aanvragen van 61 monumenten afgewezen vanwege een ontoereikend budget (www.erfgoedmonitor.nl).

Een andere rijksstimuleringsmaatregel van het instandhoudingsregime voor monumenten is sinds de jaren zeventig de inkomensaftrek van de restauratie- en onderhoudskosten aan het eigen woonhuis en het omliggende tuin of park geweest. Tevens werden van 1982 tot 2010, in het kader van het Arbeidsplaatsenplan, door het ministerie van Sociale Zaken en Werkgelegenheid hoveniers van de stichting Particulier Historische Buitenplaatsen (PHB) ingezet ter ondersteuning van het groenonderhoud bij rijksmonumenten. Deze indirecte subsidievorm verplichtte de PHB om voor alle objecten waar ze werkzaam was beheerplannen op te stellen. De resultaten van het (historisch) onderzoek voor de beheerplannen werden ook gebruikt voor aanvullingen aan en de waardering in de omschrijving van het rijksmonument (voorheen: registeromschrijving; D'Ancona 1993, Van Herwaarden en Sluyterman van Loo 1999, Verburg 2009).

Vanuit het ministerie van Financiën (Fin) is van 2013 tot en met 2015 als economische stimuleringsmaatregel een tijdelijke btw-verlaging (6\% in plaats van $21 \%$ ) van kracht geweest (Weekers 2013). Deze maatregel was vijftien jaar eerder al op Europees niveau bepleit voor onder andere de aanleg en het onderhoud van tuinen en parken (Kamerlingh Onnes 1999). Met deze algemene maatregel is ook een extra impuls gegeven aan restauraties en instandhouding van groen erfgoed.

Ten slotte kunnen eigenaren voor grotere restauratie- en onderhoudswerkzaamheden gebruikmaken van laagrentende leningen. Dat kan via het Nationaal Restauratiefonds (NRF), het Revolving Fund (sinds 1985) en het Revolving Fund+ (sinds 2012) of via provinciale regelingen, zoals de monumentenfondshypotheken en Cultuurfonds-hypotheken.

\section{Provinciale regelingen}

Het ministerie van OCW stelt tevens sinds 2012 jaarlijks een budget beschikbaar voor restauratiewerkzaamheden via provinciale subsidieregelingen. De provincies bepalen zelf de verdeelsleutel voor restauraties van rijksmonumenten, prioriteren deze en stellen de hoogte van de subsidies vast (Zijlstra 2012b). In deze subsidieregelingen ligt de focus veelal op de gebouwde monumenten.

Bij de instandhoudingsbehoefte voor groen erfgoed worden eigenaren door de verschillende provincies op uiteenlopende wijze ondersteund. De meeste provincies bieden een pakket aan met projectgerichte subsidies voor restauratie en beheer. Hiervoor hebben zij een eigen erfgoedfonds opgericht dat naast gebouwd erfgoed ook groen erfgoed ondersteunt. Sommige provincies, zoals Flevoland en NoordHolland, ondersteunen hoofdzakelijk UNESCO Werelderfgoed-objecten. Soms ondersteunen provincies voornamelijk gebouwde monumenten, zoals in Drenthe, Groningen, Noord-Holland en Zeeland. Een van de redenen die hiervoor wordt gegeven, is dat er geen aanvragen worden ingediend voor restauraties van groen erfgoed. De provincie Drenthe ondersteunt wel de uren voor projectbegeleiding van groene restauraties.

Sommige provincies voeren naast fondsenwerving tevens een actief ondersteunend erfgoedbeleid. Zo bieden Drenthe, Gelderland, Overijssel, Utrecht en Zuid-Holland adviesloketten voor terreineigenaren, platforms voor belanghebbenden, scholing van beheerders en vrijwilligers en de mogelijkheid om ruimtelijke ordeningsinstrumenten effectiever in te zetten voor bijvoorbeeld landgoederen.

Ook zijn er provincies met een passievere rol wat betreft cultureel erfgoed, zoals Groningen, Limburg, Noord-Brabant en Noord-Holland. Zij hebben hun takenpakket verlegd van subsidiabel beheer naar participatie met uitvoerende beheerinstanties, zoals de provinciale landschappen en landschapsbeheerstichtingen. 


\subsubsection{Conclusie beleidsdoelen en instrumenten}

De instandhouding en bescherming van groen erfgoed heeft in de afgelopen eeuw een belangrijke positie verworven in het overheidsbeleid. Met diverse instrumenten wordt een grote inspanning verricht om alle betrokkenen (eigenaren, adviseurs, gemeenteambtenaren en ontwikkelaars) bewust te maken hoe duurzaam behoud en gebruik bij dit specifieke cultuurgoed in de praktijk gebracht kunnen worden. Daarbij zijn kennisdeling en voorlichting belangrijke pijlers, naast het bieden van financiële ondersteuning.

\subsection{Externe invloeden op onderhoud en onderhoudsstaat}

Naast de beleidsinstrumenten voor bescherming en instandhouding van groene rijksmonumenten zijn ook andere externe factoren van invloed op de onderhoudsstaat en het benodigde onderhoud van groen erfgoed. Door klimaatverandering is het groeiseizoen merkbaar langer geworden. Gazons moeten vaker worden gemaaid en er is een langere doorlooptijd van het onkruidbeheer. Het veranderende klimaat zorgt ook voor een toename in boom- en plantenziektes. Een voorbeeld is de kastanjebloedingsziekte, waardoor veel kastanjes vroegtijdig geveld moeten worden. Maar ook andere boomsoorten zoals es, esdoorn en plataan worden bedreigd door nieuwe ziektes en plagen (bijv. Moraal e.a. 2004). Dit geldt ook voor heesters. Buxus, een van de meest beeldbepalende voorbeelden van groen erfgoed, wordt aangetast door een schimmelziekte. Om een voorbeeld te noemen: in de siertuinen van Paleis het Loo is om deze reden 28 kilometer buxushaag vervangen.

Ook verdroging en verslechterde waterkwaliteit kunnen van invloed zijn op de staat en het beheer van groen erfgoed. Op veel plaatsen kampen vijvers en grachten met een te lage waterstand. Sommige eigenaren moeten grondwater oppompen om onderdelen van hun aanleg nat genoeg te houden. Het waterdicht maken of oppompen van grondwater zorgt voor extra kosten. Verdroging, maar ook een hoger waterpeil (vanwege natuurwaarden of het opvangen van piekbelastingen), kan leiden tot het moeten vervangen van beplanting.

Wet- en regelgeving die niet primair op groen erfgoed is gericht, kan toch van invloed zijn op groene monumenten en hun onderhoud. Door het verbod op glyfosaat is onkruidbeheer op verharding veel arbeidsintensiever geworden. Nieuwe bestrijdingsmethoden zijn beschikbaar, maar minder effectief om het gewenste onkruidvrije beeld te bereiken. Bovendien moet schade aan historische verhardingsmaterialen worden voorkomen.

Ten slotte ervaren beheerders soms dat in en rond belangrijke natuurgebieden zoals Natura 2000 gestreden moet worden voor de eigen positie en vereisten van groen erfgoed in het terreinbeheer. $\mathrm{Er}$ wordt dus niet altijd op een zelfde wijze gekeken naar groen erfgoed.

De hierboven geschetste externe invloeden hebben gevolgen voor het in een redelijke staat houden van groene monumenten, zowel wat betreft de benodigde tijdsinspanning als de materiaalkeuze. In het algemeen hebben ze een kostenverhogende werking. Deze consequenties zijn in deze studie niet gekwantificeerd en doorgevoerd in het gebruikte standaardbegrotingsmodel. Hierdoor zijn de financiële gevolgen van deze externe invloeden niet zichtbaar. 


\section{Gevolgde methode}

\subsection{Inventarisatie en categorisering groen erfgoed}

Ter voorbereiding van dit onderzoek heeft de RCE eind 2015 een inventarisatie van de actuele rijksbeschermde groenaanleg uitgevoerd op basis van het monumentenregister. Het doel van deze inventarisatie was het verbeteren van bestaande lijsten van rijksmonumenten met een beschermde groenaanleg. Die lijsten zijn in 2005/2006 aangelegd door de RCE. De indeling in categorieën erfgoed van die lijsten is bij de verbeterslag in 2015 grotendeels gehandhaafd. Dit bood de mogelijkheid om in het monumentenregister te zoeken op vergelijkbare termen. Door de verbeterde zoekmogelijkheden in 2015, waarbij zoektermen (Booleaans) konden worden gecombineerd, zijn ongeveer honderd extra objecten getraceerd. Daarnaast zijn de lijsten aangevuld met behulp van categoriale inventarisaties die in de tussenliggende periode beschikbaar zijn gekomen (bijvoorbeeld villatuinen, begraafplaatsen, stadsparken).

Het waarderen, aanwijzen en in stand houden van monumenten is altijd gerelateerd aan de gebeurtenissen, prioriteiten en de maatschappelijke 'bril' in een bepaalde periode. Iedere tijd kent zijn eigen problemen, met teloorgang van bepaalde categorieën erfgoed tot gevolg. Het werken met categorieën erfgoed is op die manier ontstaan. Zo kon een onderverdeling worden gemaakt in de 62.000 gebouwde rijksmonumenten die Nederland telt en konden problemen rondom instandhouding per categorie worden aangepakt. Uitleg van de categorieën groen erfgoed is beschikbaar op de Erfgoedthesaurus (http://www.erfgoedthesaurus. $\mathrm{nl} /$ ).

\subsection{Steekproef}

\subsubsection{Relevante begrippen}

Steekproeven hebben hun eigen jargon. In deze paragraaf gaan we in op de betekenis van een aantal begrippen die verbonden zijn met steekproeven. Dat doen we ter verheldering van de hierna volgende beschrijvingen over de gehanteerde steekproef en de statistische verwerking van de resultaten ervan.

Allereerst maken we onderscheid tussen de populatie en een steekproef. Statistici verstaan onder een populatie de totale verzameling eenheden waarover uitspraken moeten worden gedaan. In deze studie bestaat de populatie uit alle rijksmonumenten met beschermde groenaanleg. Voor het doel van dit onderzoek zijn de Nederlandse rijksmonumenten met beschermde groenaanleg onderverdeeld in 14 categorieën groen erfgoed (Tabel 2). De uitspraken die in deze studie worden gedaan over deze populatie betreffen de onderhoudsstaat en de onderhoudskosten van het groene erfgoed.

Vaak laten beschikbare middelen (tijd en geld) niet toe dat de hele populatie wordt onderzocht om tot de gevraagde uitspraken te komen. Dat is ook in dit onderzoek het geval: de totale populatie bevat iets minder dan 1.400 objecten verspreid over Nederland. Het is onmogelijk deze allemaal in de veldinventarisatie op te nemen. Om deze reden wordt in veel onderzoeken gebruikgemaakt van steekproeven. Een steekproef is een verzameling waarnemingen aan een deel van de eenheden uit de populatie. In een steekproef worden de eenheden waarop de waarnemingen betrekking hebben door een specifieke procedure geselecteerd en vinden de waarnemingen (metingen) plaats op een systematische, gestandaardiseerde manier. Door zo te werk te gaan, kunnen we verwachten dat de uitspraken die we op basis van de steekproefresultaten doen een zuiver beeld geven van de hele populatie. Maar omdat we in de steekproef maar een deel van de eenheden (in dit geval groen erfgoed-objecten) uit de populatie onderzoeken, zal er aan de uitkomsten altijd een bepaalde mate van onzekerheid zijn verbonden. Wanneer de selectie van de eenheden volgens een goed gedefinieerde steekproefopzet plaatsvindt, kan deze mate van onzekerheid gekwantificeerd worden. In 
dit onderzoek is deze onzekerheid gekwantificeerd met de standaardafwijking van de geschatte onderhoudsstaat en onderhoudskosten. Deze standaardafwijking geeft aan hoe sterk de schattingen variëren als de steekproef heel vaak herhaald zou worden en dus steeds andere eenheden geselecteerd zouden worden met als gevolg steeds andere schattingen. De standaardafwijking heeft dezelfde eenheid als het gemiddelde (bijvoorbeeld eenheid onderhoudsklasse, of $€$ ).

Een steekproef kan aselect of niet-aselect zijn. Aselect betekent dat de selectie (of 'trekking') van eenheden (in dit geval objecten) uit de populatie die in de steekproef worden opgenomen, gebeurt door loting. Het toeval bepaalt dan welke objecten in de steekproef terechtkomen. Objecten kunnen echter ook op een andere manier worden geselecteerd, waarbij loting of het toeval geen rol speelt. Dan spreken we van een niet-aselecte trekking. Een aselecte steekproef betekent dat alle eenheden in de populatie een bekende kans hebben om in de steekproef terecht te komen. Bij een niet-aselecte steekproef is dat niet zo. De objecten in de steekproef van dit onderzoek zijn voor het grootste deel door loting geselecteerd. De gevolgde procedure wordt nader toegelicht in paragraaf 3.2.2.

Bij onderzoek dat gebruikmaakt van een steekproef kan het wenselijk zijn uitspraken te doen over delen van de populatie. Denk daarbij bijvoorbeeld aan categorieën groen erfgoed, regio's of categorieën eigenaren. Het schatten van gemiddelden en totalen per deelpopulatie is eenvoudig wanneer hiermee rekening wordt gehouden bij de opzet van de steekproef. Dat kan door stratificatie, waarbij uit elke deelpopulatie (we noemen dit hieronder een stratum, meervoud strata) een deel van de eenheden wordt ingeloot. Bij het ontwerp van de steekproef voor dit onderzoek zijn de categorieën groen erfgoed gebruikt als strata (Figuur 1, Tabel 2). Binnen elk van de 14 categorieën is $15 \%$ van de objecten geselecteerd. Zonder stratificatie zou het bij aselecte trekking mogelijk zijn geweest dat bepaalde categorieën sterk ondervertegenwoordigd en andere sterk oververtegenwoordigd zijn. Immers, de loting is gebaseerd op toeval. In het ontwerp van de steekproef die in dit onderzoek is gebruikt, zijn in de stratificatie alleen de categorieën groen erfgoed meegenomen, niet de provincies of categorieën eigenaren. Deze laatste waren ook niet bekend op populatieniveau (dus voor alle rijksmonumenten met beschermde groenaanleg in Nederland).

\section{Gestratificeerde aselecte steekproefname}

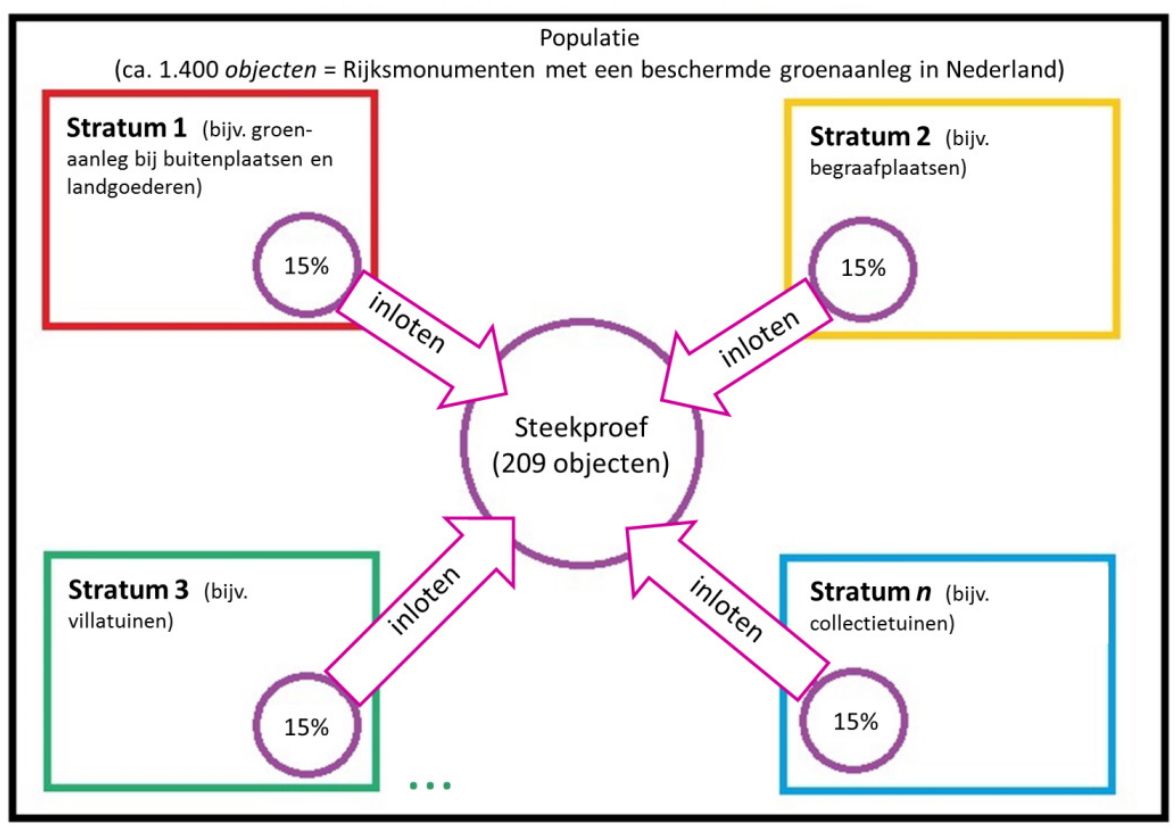

Figuur 1 Schematische weergave van een gestratificeerde aselecte steekproef. Aangepast naar Wikipedia.org, lemma stratified sampling. 


\subsubsection{Samenstelling door RCE aangeleverde steekproef}

Uit een inventarisatie die eind 2015 door de RCE is gedaan, blijkt dat er sprake is van bijna 1.400 rijksmonumenten met een beschermde groenaanleg. Hieruit heeft de RCE een steekproef van $15 \%$ getrokken. De steekproef heeft een landelijke spreiding en bestaat uit 209 rijksmonumenten met een beschermde groenaanleg. De monumenten zijn verdeeld in 14 categorieën. Uit iedere categorie is $15 \%$ van de monumenten in de steekproef opgenomen (Tabel 2). Voor de collectietuinen zou dit na afronding op slechts één monument neerkomen. Daarom is in die categorie voor een extra monument in de steekproef gekozen (22\% van totaal).

De steekproefneming is gedaan zonder 'teruglegging', dat wil zeggen dat een object dat eenmaal geselecteerd is voor de steekproef niet nogmaals geselecteerd kan worden.

Tabel 2 Bij de steekproef gehanteerde categorieën groen erfgoed en aantal objecten per categorie.

\begin{tabular}{lr} 
Categorie (2015) & Aantal geselecteerde objecten \\
Groenaanleg bij buitenplaatsen \& landgoederen & 85 \\
\hline Begraafplaatsen & 38 \\
\hline Villatuinen & 15 \\
\hline Boerentuinen en boerenerven & 11 \\
\hline Stadsparken en plantsoenen & 10 \\
\hline Groenaanleg bij religieuze gebouwen & 9 \\
\hline Stadstuinen & 8 \\
\hline Groenaanleg bij medische en sociale instellingen & 7 \\
\hline Tuinen en parken bij landhuizen & 6 \\
\hline Erven & 5 \\
\hline Diversen & 5 \\
\hline Pastorietuinen & 4 \\
\hline Tuinen bij bedrijven, overheid en organisaties & 4 \\
\hline Collectietuinen & 2 \\
\hline Totaal in steekproef & 209 \\
\hline
\end{tabular}

De steekproef is gedeeltelijk aselect en gedeeltelijk niet-aselect getrokken. Eerst is aselect $15 \%$ van de monumenten uit een categorie ingeloot en vervolgens is binnen die selectie een check gemaakt op de representativiteit van de samenstelling van de steekproef. Daarbij is gekeken of de verschillende typen aanleg binnen de categorieën vertegenwoordigd zijn. Op basis van de uitkomsten zijn gericht wijzigingen aangebracht in de samenstelling van de steekproef om alle typen aanleg in de steekproef te laten voorkomen.

Verdedigingswerken zijn in dit onderzoek op verzoek van de opdrachtgever buiten beschouwing gelaten, omdat de scheidslijn tussen gebouwd en groen binnen deze categorie diffuus is. Ondanks een dekking met gras gaat het bij deze aardwerken feitelijk niet om groene monumenten. Slechts in een beperkt aantal gevallen is er voor deze monumenten typerend 'verdedigingsgroen' geconstateerd/ beschermd. De aard en de als sober aan te merken intensiteit van de instandhoudingswerkzaamheden aan dit verdedigingsgroen, wijken af van die bij andere categorieën groen erfgoed. De stadswallen die later zijn gewijzigd in stadsparken zijn via de rubriek van de stadsparken en plantsoenen wel in dit onderzoek opgenomen.

\subsubsection{Aanpassing steekproef op basis van respons eigenaren}

Als eerste stap in het onderzoek zijn alle eigenaren schriftelijk benaderd met het verzoek om toestemming voor de inventarisatie van hun groenaanleg. Voor een dertiental objecten uit de oorspronkelijke steekproef heeft de eigenaar uiteindelijk geen toestemming gegeven. Daarnaast kon een aantal eigenaren niet tijdig worden bereikt. Daarom is de steekproef via een selecte trekking aangevuld met vervangende objecten uit dezelfde categorie. In overleg met de RCE zijn deze zo veel mogelijk 
gekozen in de nabijheid van het afvallende object. In de uiteindelijke steekproef zijn 21 vervangende objecten opgenomen.

In de uiteindelijke steekproef is de aantalsverdeling van de 209 objecten over de 14 onderscheiden categorieën groen erfgoed precies dezelfde als in de oorspronkelijke steekproef (paragraaf 3.2.1). Hetzelfde geldt voor de verdeling van de objecten over de provincies, met één uitzondering: voor een stadstuin in Noord-Holland is een vervangend object gevonden in het aangrenzende deel van de provincie Utrecht. Op basis hiervan is bij de verdere uitwerking uitgegaan van een volledig aselecte steekproef.

\subsection{Voorbereiding voor de veldinventarisatie}

Voordat de 209 geselecteerde groene rijksmonumenten in het veld konden worden bezocht en geïnventariseerd, is een aantal voorbereidende stappen doorlopen. Deze worden hieronder toegelicht.

\subsubsection{Begrenzen van de objecten in de steekproef}

Voor de begrenzing van de rijksbeschermde groenaanleg bij buitenplaatsen en landgoederen kon in de meeste gevallen gebruik worden gemaakt van de GIS-kaart met buitenplaatsen (downloadbaar via http://cultureelerfgoed.nl/dossiers/groen-erfgoed/kaart-met-buitenplaatsen. Bij twijfel werd de omschrijving (met opgave van kadastrale percelen) in het digitale monumentenregister (http://monumentenregister.cultureelerfgoed.nl/php/main.php) geraadpleegd.

Voor de overige objecten is de informatie op het digitale monumentenregister als eerste uitgangspunt genomen, in het bijzonder de omschrijving van het rijksmonument en het overzicht van kadastrale percelen die tot het beschermde gebied behoren.

Ter verdere controle van de begrenzing is een vergelijking gemaakt met recente of oudere plattegronden van de groenaanleg, voor zover deze beschikbaar waren. In enkele gevallen konden deze plattegronden door de eigenaren worden aangeleverd. Soms werden ze online gevonden, bijvoorbeeld via de TUiN database (http://www.wageningenur.nl/en/Expertise-Services/Facilities/Library/SpecialCollections.htm\#tuin). Een bijkomend voordeel van de raadpleging van deze plattegronden was dat ze soms nuttige informatie gaven voor de opmaak van de basiskaarten (paragraaf 3.3.2).

\subsubsection{Opmaken basiskaarten per object}

Binnen de begrenzingen van de objecten zijn de aanwezige groenelementen gekarteerd in ArcGIS ( Pro 1.2 en 1.3. De groenelementen zijn volgens de Leidraad subsidiabele instandhoudingskosten 2013 ingedeeld in prioriteit 1 of 2 en overige elementen zoals bouwland en productie- of natuurbos. Bijlage 2 geeft per elementtype aan welke prioriteit er is toegekend.

De digitale kaartbestanden die voor dit onderzoek beschikbaar waren (zoals de topografische kaart 1:10.000 en de Basisregistratie Grootschalige Topografie), bleken om verschillende redenen onvoldoende bruikbaar:

- Te kleinschalig, waardoor voor dit onderzoek belangrijke detailinformatie ontbreekt. Dit geldt bijvoorbeeld voor de topografische kaart 1:10.000.

- Cartografisch product, waardoor in combinatie met het vorige punt de gekarteerde situatie plaatselijk sterk afwijkt van de situatie zoals die in het veld kan worden waargenomen. Ook dit geldt vooral voor de topografische kaart 1:10.000.

- Onvoldoende detail.

Daarom zijn er nieuwe basiskaarten aangemaakt (handmatig gedigitaliseerd) op basis van hoge-resolutie luchtfoto's en het Actueel Hoogtebestand Nederland (AHN2). In sommige gevallen werd dit gecombineerd met illustratief kaartmateriaal van objecten dat als pdf beschikbaar was. Waar nodig is aanvullend ook gebruikgemaakt van Google Streetview en Globespotter (actuele hoge-resolutie luchtfoto's; https://globespotter.cyclomedia. $\mathrm{nl} / \mathrm{nl} /$ ). De schaal waarop is gekarteerd, lag meestal rond 1:1000. Voor het karteren van details zoals bloemperken is soms ingezoomd tot een schaal van ca. 1:200. 


\subsubsection{Op maat maken en testen Collector-app}

Ten behoeve van de veldinventarisatie is een app op maat gemaakt. Vertrekpunt hiervoor was de beschikbare ESRI Collector app for ArcGIS. Met behulp van de app kunnen in het veld foutief begrensde of benoemde groenelementen worden gecorrigeerd en ontbrekende elementen worden toegevoegd. Verder kunnen de afmetingen van de elementen en de onderhoudsstaat met de app worden vastgelegd. Ten behoeve van een gestandaardiseerde data-invoer kan bij de invoer gebruik worden gemaakt van dropdownmenu's, bijvoorbeeld bij de keuze van het elementtype en de onderhoudsstaat (Figuur 3).

In een praktijkdemo van een dagdeel is de app geïntroduceerd bij de veldwerkers. Naar aanleiding van hun feedback is de app verder geoptimaliseerd wat betreft gebruiksgemak en herhaalbaarheid. Dit heeft technisch gezien geen invloed gehad op het proces van gegevensverzameling. Ook de opdrachtgever en klankbordgroep hebben kunnen kennismaken met een eerste versie van de app.

Een verdere indruk van de werking en mogelijkheden van de Collector-app kan worden verkregen via www.esri.com/collectorapp.

\subsubsection{Opstellen beeldkwaliteitsdocument}

Als referentiekader voor het objectief beoordelen van de onderhoudsstaat van de in het veld aangetroffen elementen is in het kader van dit onderzoek een beeldkwaliteitsdocument opgesteld (Debie \& Verkuijl 2016). Het bepalen van kwaliteit is afhankelijk van de beoordelaar en daardoor subjectief. Het ontwikkelde beeldkwaliteitsdocument draagt bij aan een objectief inventarisatiesysteem dat door zijn gestandaardiseerde en herhaalbare opzet tevens overdraagbaar is aan toekomstige beoordelaars.

Alle elementtypen waarvan de onderhoudsstaat is opgenomen, zijn in het beeldkwaliteitsdocument beschreven. Per elementtype zijn vier foto's uit de Nederlandse praktijk opgenomen als referentiebeeld voor de verschillende klassen van de onderhoudsstaat (Tabel 3). Bij elke foto is een korte tekstuele toelichting gegeven (Figuur 2).

\section{BOMEN (SOLITAIREN EN BOOMGROEPEN)}

GOED

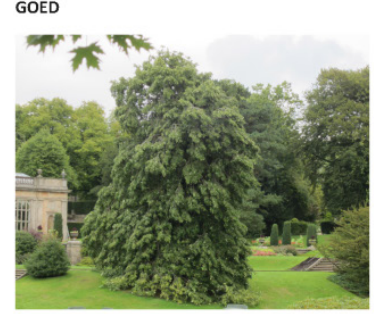

De kroon heeft een fraaie natuurlijke en gelijkmatige vorm, met een goede bladbedekking en vertoont een sterke groeikracht. De bomen zijn frequent en professioneel gesnoeid. De stam is gaaf en vital en is onbeschadigd aan de stamvoet.

Gelijkmatige takverdeling.

Snoeisporen klein.

Nauwelijks dood hout.

stam- en stamvoetconditie

Goede rechtstand.

Geen inrottingssporen of zwammen

zichtbaar.

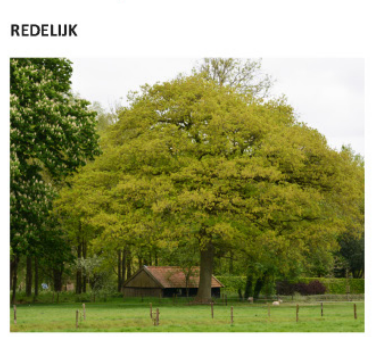

De boom heeft nog een herkenbare natuurlijke vorm, met enige onregelmatigheden. De bladbedekking is overwegend dekkend. De bomen zijn minder frequent gesnoeid, waarbij grot snoeisporen zich bar zlin. Desta is maaischade zichtbaar aan de stamvoet.

takverdeling en snoeisporen

Overwegend gelijkmatige takverdeling. Snoeisporen klein tot groot. Dood hout aanwezig.

stam- en stamvoetconditie

Enigszins scheefstand.

Nauwelijks inrottingssporen of zwammen zichtbaar. Enige afwijkende rechtstand.

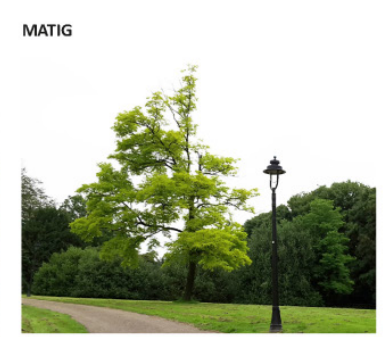

Boom heeft verminderde groei en bladbedekking, en oogt duidelijk in verslechterde toestand. De kroonvorm is onregelmatig en aangetast door grote uitval of te hoog opgekroond. De takken missen groeieinden. Het is zichtbaar aan de snoeisporen dat er in het verleden grote snoeiachterstand is geweest. De is zich th va stanis maaiwerkzaamheden.

takverdeling en snoeisporen

Zichtbare takuitval en enige kroonsterfte. Zichtbare snoeiachterstand door grote snoeiwonden. Boom is met snoei nog in stand te houden

stam- en stamvoetconditie

Veel uitval en inboet $>30 / 40 \%$.

Meerdere inrottingssporen of zwammen zichtbaar. Mogelijke scheefstand of zichtbar. Mogelijk.
stambeschadiging.

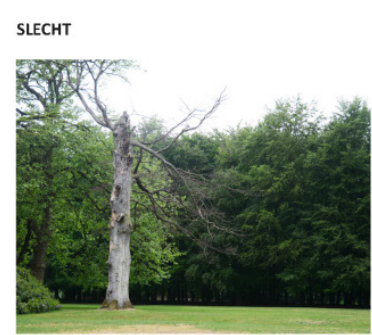

Boom heeft meer dan de helft van de kroo verloren en is half dood. Er is geen sprake meer van een herkenbare kroonvorm. De stamvoet is ernstig beschadigd door maaiwerkzaamheden en niet meer vitaal. De aanhechting met de wortels is zichtbaa slecht. Zwammen zijn herkenbaar op de stam. Vervangende jonge bomen die naast ep verkeerde plek of de verdichten, kunnen of

takverdeling en snoeisporen

Zware takuitval en ernstige kroonsterfte. Zichtbare snoeiachterstand waarbij boom ook met snoei niet meer te redden is.

stam- en stamvoetconditie

Veel uitval en inboet $>60 \%$. Holle stam met grote mate van Gevaarlike scheefstand of duidelijke stambeschadiging.

Figuur 2 Voorbeeldblad uit het beeldkwaliteitsdocument (Debie \& Verkuijl 2016). 


\subsection{Veldinventarisatie}

Alle 209 objecten zijn bezocht door een van de veldmedewerkers. Binnen een object is van alle aangetroffen elementen vastgelegd om welk elementtype het gaat en wat de afmetingen zijn (voor zover dit onvoldoende vast lag in de basiskaart of niet correct was). Om welk elementtype het gaat, is bepaald op basis van de huidige aanblik van een element, niet op basis van de vroegere situatie die soms nog herkenbaar is. Een moestuin bijvoorbeeld is geïnventariseerd als moestuin zolang hij de aanblik heeft van een moestuin (ook al is deze in een slechte staat). Is een moestuin omgevormd naar een bloemperk, dan is het element als bloemperk vastgelegd.

De onderhoudsstaat is op een gestandaardiseerde manier geschat met behulp van het beeldkwaliteitsdocument (Debie \& Verkuijl 2016); zie Tabel 3.

Deze gegevens zijn offline verzameld met behulp van de Collector-app. Na afloop van het veldwerk zijn de gegevens gesynchroniseerd met de online-database.

\section{Tabel 3 Indeling van de onderhoudsstaat in vier klassen.}

\begin{tabular}{ll} 
Klasse & Onderhoudsstaat \\
\hline 1 & goed \\
\hline 3 & redelijk \\
\hline 4 & matig \\
\hline
\end{tabular}

Ook is in het veld het type aanleg volgens de omschrijving van het rijksmonument gecontroleerd en zijn eventuele afwijkingen waar nodig genoteerd. In die gevallen waarbij er in het veld werd geconstateerd dat er sprake was van diverse typen (samengestelde) aanleg is dit in de beschrijving opgenomen.

Ten slotte is aan het eind van het veldwerk de onderhoudsstaat van het geïnventariseerde object als geheel geschat.

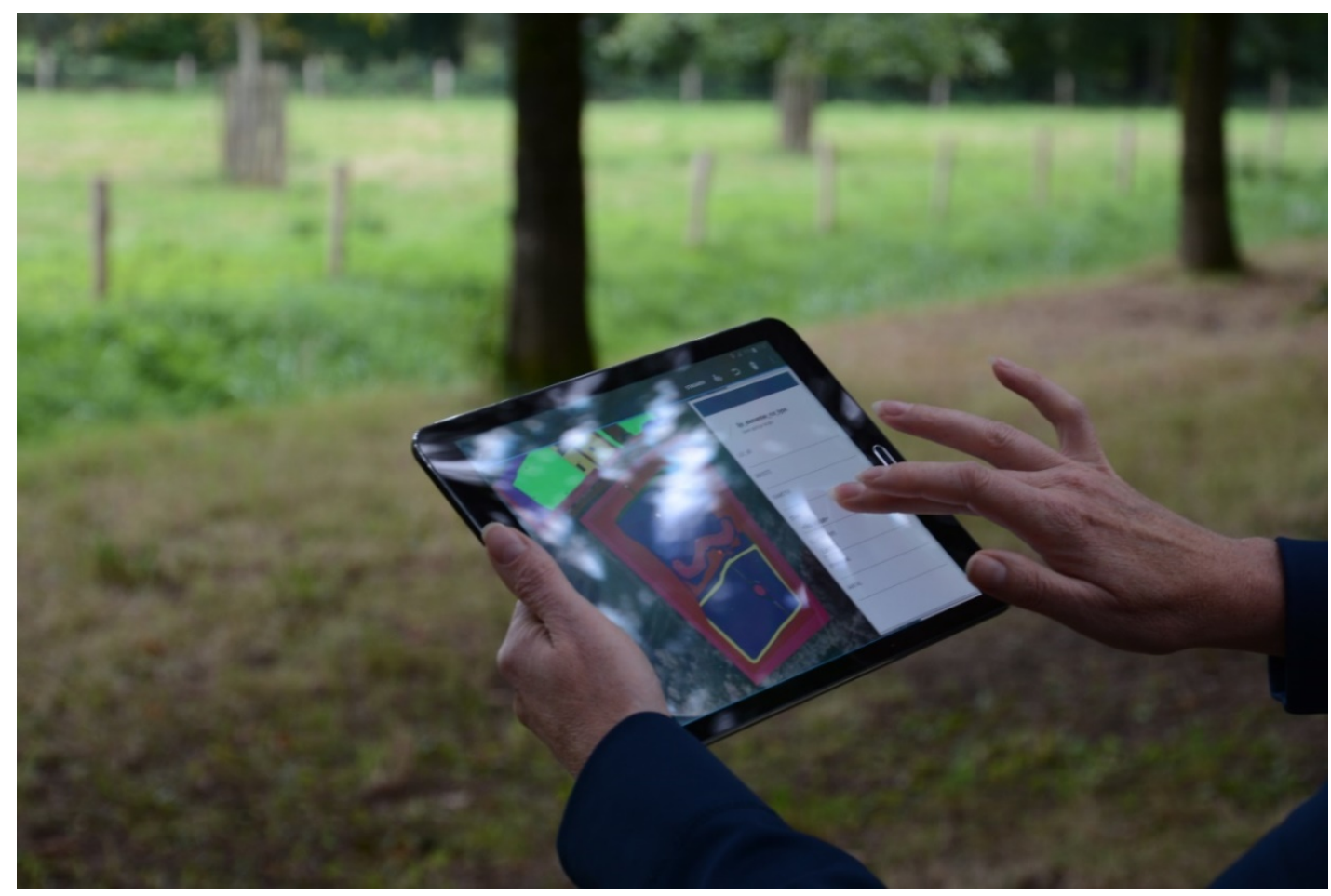

Figuur 3 Het veldwerk is verricht met een tablet met daarop de Collector-app. In de app zit een plattegrond van het object en de groenelementen daarbinnen. Ter plekke is de staat van het object per element geïnventariseerd en verwerkt via een dropdownmenu (wit vlak rechts op de tablet). 


\subsection{Analyse van de verzamelde gegevens}

\subsubsection{Gegevensvoorbewerking}

De veldgegevens zijn bewerkt om tot de eindresultaten te komen. Deze voorbewerking van de data dient twee doelen: (1) een kwalitatieve controle van alle gegevens en (2) opname in een format waarmee verder kan worden gerekend in de uitwerking van de steekproef. Bij de kwalitatieve controle zijn de begrenzingen van de objecten nog eenmaal gecontroleerd, tekstuele opmerkingen uit het veld in de dataset verwerkt en een uitgebreide controle op de topologie uitgevoerd. Met deze laatste actie (topologiecontrole) wordt nagegaan of er in de GIS-database fouten aanwezig zijn, zoals dubbele en/of overlappende vlakken.

\subsubsection{Berekening onderhoudsstaat per elementtype en per object}

Tijdens de veldinventarisatie is de onderhoudsstaat van elk aangetroffen groenelement opgenomen. $\mathrm{Na}$ afloop van de inventarisatie zijn hieruit per onderzocht elementtype berekend:

- Modale onderhoudsstaat (modus): de meest voorkomende waarde voor onderhoudsstaat binnen het betreffende elementtype.

- Gemiddelde onderhoudsstaat: het gemiddelde van de waarden van elk geïnventariseerd element dat tot het betreffende elementtype behoort.

- Standaardafwijking onderhoudsstaat: een maat voor de spreiding rond het gemiddelde (zie paragraaf 3.2.1).

Tevens zijn de modale en gemiddelde onderhoudsstaat en de standaardafwijking berekend per geïnventariseerd object. Dit is gedaan door de modus, het gemiddelde en de standaardafwijking te berekenen over de scores van alle opgenomen elementen binnen het betreffende object. In een afzonderlijke berekening is hierbij aanvullend een uitsplitsing gemaakt naar prioriteit van het elementtype (prioriteit 1, 2 of 'geen'; Bijlage 2).

\subsubsection{Kostenberekening onderhoud groenaanleg}

De berekening van de onderhoudskosten voor de diverse groenelementen heeft als basis het RCEstandaardbegrotingsmodel groen, versie 8-9-2015. Bij de kostenberekening is gebruikgemaakt van diverse bestaande tijd- en kostennormen gebaseerd op de Leidraad subsidiabele instandhoudingskosten 2013. Dit omwille van de herhaalbaarheid van dit onderzoek. Daarnaast zijn er generieke aannamen gedaan voor onderdelen die in het kader van dit onderzoek niet locatiespecifiek in het veld bepaald konden worden. Voorbeelden zijn plantafstanden van bomen in lanen en de snoeihoogteverdeling van bomen.

(Voor een uitgebreidere toelichting op de kostenberekening: zie Bijlage 3.)

De onderhoudskosten die in dit rapport gepresenteerd worden, zijn inclusief indirecte kosten zoals gespecificeerd in Tabel 4.

Tabel 4 Samenstelling indirecte kosten in dit onderzoek.

\begin{tabular}{|c|c|c|}
\hline onderdeel indirecte kosten & gehanteerd percentage & toelichting \\
\hline onvoorzien & $5 \%$ & $\begin{array}{l}\text { maximumpercentage volgens RCE- } \\
\text { standaardbegrotingsmodel }\end{array}$ \\
\hline directiekosten - opstellen instandhoudingsplan & $3 \%$ & keuze in overleg met RCE \\
\hline directiekosten - jaarlijkse begeleiding & $6 \%$ & keuze in overleg met RCE \\
\hline adviseurs & 0 & moeilijk in vast percentage uit te drukken \\
\hline leges & $0 \%$ & keuze in overleg met RCE \\
\hline indexeringspercentage & $3 \%$ & keuze in overleg met RCE \\
\hline btw & $21 \%$ & keuze in overleg met RCE \\
\hline Totaal percentage indirecte kosten & $38 \%$ & \\
\hline
\end{tabular}


De onderhoudskosten zijn berekend per elementtype per object. Dit maakte het mogelijk de kosten in de analysefase op diverse manieren te sommeren: per categorie groen erfgoed, per categorie eigenaar, per provincie en per elementtype (dat wil zeggen de totale kosten per elementtype op steekproefniveau).

Tevens is bij de kostenberekening ingeschat of het nodig is voor sober en doelmatig onderhoud af te wijken van de frequenties uit de Leidraad (Bijlage 2). In die gevallen zijn ook op basis van deze afwijkende frequenties kosten berekend.

Inhoudelijke toetsing van het voor de kostenberekening gebruikte RCE-standaardbegrotingsmodel groen was geen onderdeel van dit onderzoek. Wel is evident dat een aantal normen in het model inmiddels afwijkt van wat in de praktijk gangbaar en haalbaar is. Zo zijn de uurlonen de laatste jaren gestegen. Ook een aantal tijdsnormen voor onderhoud in het RCE-standaardbegrotingsmodel groen vragen aandacht. Een voorbeeld is het snoeien van fruitbomen. Hiervoor rekent het standaardbegrotingsmodel met 1 uur per boom, terwijl het snoeien van een oude fruitboom aanzienlijk meer tijd vergt. Daarentegen wordt bij het onderhouden van heestergroepen en borders een vrij ruime tijdsnorm gehanteerd.

\subsubsection{Categorisering van eigenaren}

Ten behoeve van de data-analyse zijn de objecten onder meer ingedeeld naar het type eigenaar. Daarbij onderscheiden we vier categorieën eigenaar:

- Erfgoed in publieke handen. Dit betreft objecten in eigendom van een overheid (rijk, provincie, gemeente of waterschap).

- Erfgoed in particuliere handen. Behalve natuurlijke personen kunnen dit ook rechtspersonen zijn, bijvoorbeeld een stichting opgericht vanuit familiebezit dat uit meerdere onderdelen kan bestaan, maar slechts één groen object betreft. Een andere groep rechtspersonen die in de categorie particuliere eigenaren valt, zijn kerkgenootschappen (van belang bij bijvoorbeeld kerkelijke begraafplaatsen).

- Erfgoed beherende instellingen. Deze categorie onderscheidt zich van de vorige doordat erfgoed beherende instellingen per definitie meer dan één object beheren. De betreffende organisaties zijn veelal opgericht vanuit behoudsdoelstellingen voor rood erfgoed. Een voorbeeld van een erfgoed beherende instelling is Vereniging Hendrick de Keyser, die circa 406 objecten in heel Nederland beheert.

- Terreinbeherende organisaties. Hiertoe behoren Staatsbosbeheer, Natuurmonumenten en de diverse provinciale Landschappen. Deze categorie verschilt op een aantal manieren van de erfgoed beherende instellingen. Terreinbeherende organisaties zijn traditioneel vaak beter thuis in groen, met natuurbeheer als een belangrijke kerntaak. De mate waarin ze zich ook op (rood) erfgoed richten, varieert tussen organisaties. Een ander verschil met erfgoed beherende instellingen is dat het bij terreinbeherende organisaties vaak gaat om objecten met een grotere omvang (oppervlakte).

Sommige objecten in de geïnventariseerde steekproef hebben meerdere eigenaren, soms ook uit verschillende categorieën. De nadruk is dan gelegd bij de eigenaar die het grootste grondbezit heeft. Zo is bijvoorbeeld een landgoed dat particulier eigendom is, maar waar het omliggende parkbos aan een terreinbeherende organisatie is overgedragen, bij deze laatste categorie ingedeeld.

\subsubsection{Uitgesloten of ontbrekende onderdelen}

Bij deze monitoring van de 209 objecten is een zevental groene elementtypen wel geïnventariseerd, maar niet in de gestandaardiseerde kostenberekening meegenomen. Dit zijn elementen die deels wel in de Sim worden genoemd, maar niet in de Leidraad als subsidiabel zijn aangemerkt. De gestandaardiseerde kostenberekening is beperkt tot elementen die zijn opgenomen in het RCEstandaardbegrotingsmodel groen (d.d. 8-9-2015). Voor de zeven elementtypen in kwestie is een aanvullende schatting gemaakt van de jaargemiddelde onderhoudskosten. De aannamen die hierbij zijn gehanteerd, staan in Bijlage 6. Het resultaat van de aanvullende schatting is opgenomen in paragraaf 5.1.8. 
Daarnaast is er geen rekening gehouden met een mogelijke verschraling van de aangetroffen historische aanleg om het onderhoud te vereenvoudigen en zo goedkoper te maken. Dit kan bijvoorbeeld tot uiting komen in verdwenen onderhouds-intensieve elementen zoals parterres of bloemperken. Ook is het mogelijk dat onderhouds-intensieve elementen zoals gazons zijn omgevormd in extensievere elementen zoals parkweiden of ruigtes. Hierdoor kan een object weliswaar in een goede onderhoudsstaat verkeren, maar aanzienlijk afwijken van het historische beeld. Doordat er vooraf geen historisch onderzoek per object heeft plaatsgevonden, maar alleen de omschrijving van het rijksmonument is geraadpleegd, is niet duidelijk of er onderdelen ontbreken die er ooit wel waren. Zou worden gekeken naar de mogelijke restauratieopgave, dan kan niet worden uitgesloten dat sommige objecten waarvan de onderhoudsstaat in deze inventarisatie als redelijk of goed is beoordeeld, toch voor restauratie in aanmerking komen.

\subsection{Extrapolatie van steekproef naar heel Nederland}

In paragraaf 3.1 hebben we de steekproefopzet beschreven zoals die in dit onderzoek is toegepast. In deze paragraaf gaan we in op hoe we de resultaten van deze steekproef vertalen naar het niveau van alle rijksmonumenten met beschermde groenaanleg in Nederland. Deze vertaling noemen we extrapolatie. We extrapoleren de uitkomsten van de steekproef naar getallen en bedragen die betrekking hebben op de hele populatie.

De steekproefresultaten zijn statistisch verwerkt als gegevens van een gestratificeerde aselecte steekproef zonder teruglegging ${ }^{4}$, hoewel een deel van de objecten niet door middel van loting is geselecteerd. De strata zijn de 14 onderscheiden categorieën groen erfgoed (Tabel 2).

\subsubsection{Extrapolatie resultaten onderhoudsstaat}

De fractie objecten in de populatie ${ }^{5}$ met een bepaalde modale onderhoudsstaat (goed, redelijk, etc.) is geschat door eerst per categorie groen erfgoed (dus per stratum) de steekproef-fracties te berekenen, en vervolgens de gewogen som van deze steekproeffracties te berekenen met als gewichten de relatieve grootte van de strata (aantal objecten in een stratum gedeeld door totaal aantal objecten in Nederland). De standaardafwijking van deze geschatte fracties is bepaald met de gebruikelijke schatter voor gestratificeerde aselecte steekproeven zonder teruglegging (vgl. Lohr 1999).

\subsubsection{Extrapolatie resultaten onderhoudskosten}

De onderhoudskosten zijn geschat door eerst per categorie groen erfgoed (dus per stratum) het gemiddelde van de onderhoudskosten per object te schatten en vervolgens dit gemiddelde te vermenigvuldigen met het totaal aantal objecten in de populatie dat binnen het betreffende stratum valt. De totale kosten voor heel Nederland zijn vervolgens geschat met de som van de kosten per stratum (Lohr 1999). De standaardafwijking van deze geschatte totale kosten is bepaald met de gebruikelijke schatter voor gestratificeerde aselecte steekproeven zonder teruglegging (vgl. Lohr 1999).

\subsubsection{Extrapolatie onderhoudskosten per landsdeel}

Bij de vertaling van steekproef naar populatie konden de onderhoudskosten niet per provincie worden geschat. Dit omdat in een groot aantal combinaties van stratum (categorie groen erfgoed) en provincie waarin in de populatie wel objecten voorkomen geen objecten zijn geselecteerd voor de steekproef. Om toch uitspraken te kunnen doen over regionale verschillen, zijn de provincies geclusterd in vier landsdelen (Figuur 4). De totale onderhoudskosten per landsdeel zijn geschat door per combinatie van stratum (categorie groen erfgoed) en landsdeel de gemiddelde onderhoudskosten te schatten en deze te vermenigvuldigen met het totaal aantal objecten in de combinatie. De standaardafwijkingen van deze geschatte onderhoudskosten per landsdeel konden niet worden geschat, omdat in veel combinaties van

\footnotetext{
4 Zonder teruglegging betekent dat een object dat oorspronkelijk in de steekproef is ingeloot maar om praktische redenen (bijvoorbeeld geen toestemming van de eigenaar) niet in het onderzoek kan worden meegenomen, bij het loten van een vervangend object niet opnieuw tot de steekproef kan worden toegelaten.

5 In deze studie: alle rijksmonumenten met een beschermde groenaanleg in Nederland.
} 
stratum en landsdeel slechts één object geselecteerd is. Dit betekent dat bij de extrapolatie van de onderhoudskosten per landsdeel geen maat voor de onzekerheid van de schatting voorhanden is.

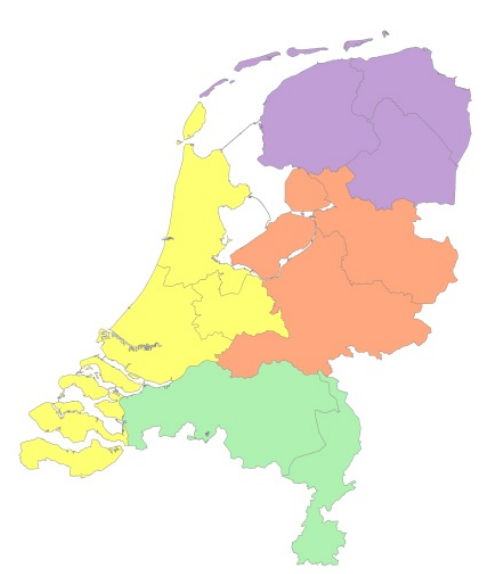

Figuur 4 Indeling van Nederland in vier landsdelen (Noord, Oost, West en Zuid). Bron: https://www.cbs.nl/nl-nl/dossier/nederland-regionaal/gemeente/gemeenten-en-regionaleindelingen/nuts-regionale-indeling-voor-europese-statistieken.

\subsubsection{Bepalingsfouten}

Het is onmogelijk de werkelijkheid zoals die in het veld is aangetroffen exact vast te leggen in een database. De onderzoeksvraag betrof een globale bepaling van de kosten. Binnen deze context is gestreefd naar volledigheid, voldoende nauwkeurigheid en herhaalbaarheid van de metingen. Zo is voor de bepaling van de onderhoudsstaat van groenelementen in het veld gewerkt met een beeldkwaliteitsdocument (paragraaf 3.3.4). De betrokkenen bij de veldinventarisatie hebben tijdens een testdag vóór de inventarisatiecampagne en ook tijdens de campagne met elkaar afgestemd over het toekennen van de scores.

Een zekere onnauwkeurigheid is echter onvermijdelijk. Een aantal foutenbronnen kan worden onderscheiden:

- Basiskaarten: fouten in begrenzing object en elementen, omissie elementen.

- Veldinventarisatie: onnauwkeurigheid bij correctie begrenzingen en intekenen ontbrekende elementen; elementen vergeten in te tekenen, verkeerd benoemd; onderhoudsstaat vergeten op te nemen of verkeerd ingeschat.

$\mathrm{Na}$ afloop van de veldinventarisaties hebben we de fouten zo veel mogelijk uit de database gehaald door controle van de opnamen, topologiechecks en andere opschoonstappen.

Ook is het van belang dat bij de toepassing van het RCE-standaardbegrotingsmodel groen generieke aannamen zijn gedaan. Een voorbeeld: voor de berekening in het standaardbegrotingsmodel moet het aantal laanbomen per strekkende meter laan bekend zijn. Om redenen van beschikbare tijd is dit aantal niet in het veld gemeten, maar via een generieke aanname over de gemiddelde plantafstand in lanen bepaald.

De in de vorige paragraaf genoemde standaardafwijkingen van de geschatte fracties en totalen zijn inclusief de standaardafwijking van bepalingsfouten. Verondersteld is dat er geen systematische bepalingsfouten zijn gemaakt, bijvoorbeeld dat de onderhoudskosten systematisch te hoog of te laag zijn ingeschat. Wel gaan we uit van een op toeval gebaseerde bepalingsfout, met een gemiddelde van 0 . De standaardafwijking van deze fout is automatisch verdisconteerd in de geschatte standaardafwijkingen zoals beschreven in de vorige paragraaf. 


\section{$4 \quad$ Onderhoudsstaat groen erfgoed}

In dit hoofdstuk presenteren we een overzicht van de onderhoudsstaat van rijksbeschermd groen erfgoed. De onderhoudsstaat is bepaald op basis van de 209 geïnventariseerde objecten (paragraaf 4.1). Op basis van deze resultaten is ook een schatting gemaakt van de onderhoudsstaat van al het rijksbeschermde groene erfgoed in Nederland (paragraaf 4.2). Zoals aangegeven in de inleiding op bladzijde 12 is in dit onderzoek alleen de staat van onderhoud vastgelegd, niet in welke mate de aanleg nog in de oorspronkelijke staat is.

\subsection{Resultaten op steekproefniveau}

De resultaten die in deze paragraaf gepresenteerd worden, hebben uitsluitend betrekking op de steekproef. Uit deze resultaten kunnen daarom alleen conclusies worden getrokken over de 209 geïnventariseerde objecten. Voor conclusies over wat dit betekent voor de onderhoudsstaat van de hele populatie rijksbeschermd groen erfgoed in Nederland wordt verwezen naar paragraaf 4.2.

\subsubsection{Verschillen tussen categorieën groen erfgoed}

De gemiddelde onderhoudsstaat van de objecten in de diverse categorieën groen erfgoed varieert globaal tussen goed en redelijk. Beschouwen we alle 209 objecten in de steekproef, dan is de eindgemiddelde onderhoudsstaat redelijk (Tabel 5). In totaal zijn er 24 objecten in de steekproef (11\%) die op objectniveau een modale onderhoudsstaat matig hebben; de score slecht komt op objectniveau niet voor. Deze objecten zijn vrij evenwichtig verdeeld over de categorieën groen erfgoed.

Op steekproefniveau is de standaardafwijking van de onderhoudsstaat het kleinst in de categorieën collectietuinen, buitenplaatsen \& landgoederen, erven en diversen (kleiner dan een halve onderhoudsklasse). Dit komt doordat de meeste objecten binnen deze categorieën dezelfde score hebben voor onderhoudsstaat. De gemiddelde scores zijn hier dan ook relatief betrouwbaar. De grootste standaardafwijking zit in de categorieën pastorietuinen en tuinen en parken bij landhuizen. Hier verschillen de objecten onderling vrij sterk in onderhoudsstaat (Tabel 5).

Tabel 5 Onderhoudsstaat per categorie groen erfgoed.*

\begin{tabular}{|c|c|c|c|}
\hline Categorie groen erfgoed & Aantal objecten & Gemiddelde staat & Standaardafwijking staat \\
\hline Groenaanleg bij medische en sociale instellingen & 7 & 1,29 & 0,49 \\
\hline Stadstuinen & 8 & 1,50 & 0,53 \\
\hline Diversen & 5 & 1,80 & 0,45 \\
\hline Tuinen bij bedrijven, overheid en organisaties & 4 & 1,88 & 0,63 \\
\hline Begraafplaatsen & 38 & 1,91 & 0,61 \\
\hline Collectietuinen & 2 & 2,00 & 0,00 \\
\hline Tuinen en parken bij landhuizen & 6 & 2,00 & 0,89 \\
\hline Groenaanleg bij buitenplaatsen \& landgoederen & 85 & 2,01 & 0,37 \\
\hline Eindtotaal & 209 & 1,91 & 0,54 \\
\hline
\end{tabular}

* De gemiddelden en standaardafwijkingen zijn berekend over de modale onderhoudsstaat van de betreffende objecten. De modale staat die aan de tabel ten grondslag ligt, kan de volgende waarden hebben: 1 (goed), 2 (redelijk), 3 (matig), 4 (slecht). De tabel is gesorteerd op de gemiddelde onderhoudsstaat. 


\subsubsection{Verschillen tussen categorieën eigenaren}

Wanneer we op steekproefniveau de gemiddelde onderhoudsstaat berekenen per categorie eigenaar, blijkt dat de waarden betrekkelijk dicht bij elkaar liggen (afgerond in elke categorie redelijk; Tabel 6).

Op steekproefniveau is de standaardafwijking van de onderhoudsstaat het kleinst in de groep objecten van terreinbeherende organisaties (ruim 1/3 onderhoudsklasse). Dit komt doordat de meeste objecten in deze categorie dezelfde score hebben voor onderhoudsstaat. De gemiddelde score is hier dan ook relatief betrouwbaar. De grootste standaardafwijking zit in de categorie erfgoed beherende instellingen. Hier verschillen de objecten onderling vrij sterk in onderhoudsstaat (Tabel 6).

Tabel 6 Onderhoudsstaat per categorie eigenaar.*

\begin{tabular}{lccr} 
Categorie eigenaar & Aantal objecten & Gemiddelde staat & Standaardafwijking staat \\
Erfgoed beherende instellingen & 48 & 1,80 & 0,63 \\
\hline Erfgoed in publieke handen & 39 & 1,91 & 0,54 \\
\hline Erfgoed in particuliere handen & 98 & 1,93 & 0,54 \\
\hline Terreinbeherende organisaties & 24 & 2,04 & 0,36 \\
\hline Eindtotaal & 209 & 1,91 & 0,54 \\
\hline
\end{tabular}

* De gemiddelden en standaardafwijkingen zijn berekend over de modale onderhoudsstaat van de betreffende objecten. De modale staat die aan de tabel ten grondslag ligt, kan de volgende waarden hebben: 1 (goed), 2 (redelijk), 3 (matig), 4 (slecht). De tabel is gesorteerd op de gemiddelde onderhoudsstaat.

\subsubsection{Verschillen tussen provincies}

Ook wanneer we de gegevens indelen naar provincie, lopen de gemiddelden van de onderhoudsstaat niet heel sterk uiteen (Tabel 7). Op steekproefniveau is in elke provincie de gemiddelde onderhoudsstaat afgerond steeds redelijk.

Op steekproefniveau was de standaardafwijking van de onderhoudsstaat het kleinst in Limburg, Zeeland, Drenthe en Noord-Brabant (0,26 tot 0,41 onderhoudsklasse). Dit betekent dat voor deze provincies de gemiddelde scores voor onderhoudsstaat relatief betrouwbaar zijn. Dit komt doordat de meeste objecten in deze provincies dezelfde score hadden voor onderhoudsstaat. Anders ligt dit in Zuid-Holland, Overijssel en Friesland. Hier zat van object tot object veel variatie in de per object vastgestelde onderhoudsstaat. Dit is weerspiegeld in de grotere standaardafwijking (Tabel 7).

\section{Tabel 7 Onderhoudsstaat per provincie.*}

\begin{tabular}{lccr} 
Provincie & Aantal objecten & Gemiddelde staat & Standaardafwijking staat \\
Noord-Brabant & 30 & 1,80 & 0,41 \\
\hline Utrecht & 26 & 1,83 & 0,51 \\
\hline Zuid-Holland & 24 & 1,83 & 0,76 \\
\hline Friesland & 16 & 1,88 & 0,62 \\
\hline Gelderland & 36 & 1,88 & 0,58 \\
\hline Zeeland & 8 & 1,88 & 0,35 \\
\hline Noord-Holland & 24 & 1,90 & 0,47 \\
\hline Limburg & 15 & 1,93 & 2,08 \\
\hline Overijssel & 12 & 2,19 & 0,26 \\
\hline Drenthe & 8 & 2,40 & 0,67 \\
\hline Groningen & 10 & 1,91 & 0,37 \\
\hline Eindtotaal & 209 & 0,52 \\
\hline
\end{tabular}

* De gemiddelden en standaardafwijkingen zijn berekend over de modale onderhoudsstaat van de betreffende objecten. De modale staat die aan de tabel ten grondslag ligt, kan de volgende waarden hebben: 1 (goed), 2 (redelijk), 3 (matig), 4 (slecht). De tabel is gesorteerd op de gemiddelde onderhoudsstaat. 


\subsubsection{Verdeling scores onderhoudsstaat geïnventariseerde elementen}

Figuur 5 toont hoe de scores voor onderhoudsstaat van de individuele geïnventariseerde groene elementen zijn verdeeld. Hieruit blijkt dat ongeveer een kwart van alle opgenomen groene elementen een score matig of slecht heeft gekregen, waarbij de onderhoudsstaat slecht maar in $3 \%$ van de gevallen voorkomt.

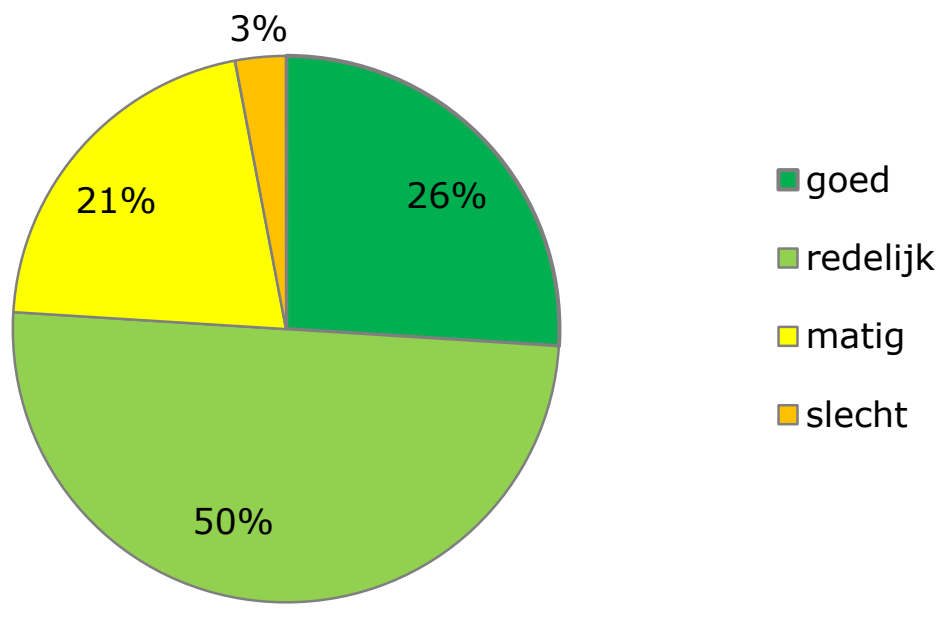

Figur $5 \quad$ Verdeling van de scores voor onderhoudsstaat over de individuele groene elementen die in de steekproef zijn geïnventariseerd.

\subsubsection{Verschillen tussen elementtypen}

Wanneer we per elementtype de meest voorkomende waarde (de modus of modale waarde) berekenen van alle individuele elementen, volgt uit Tabel 8 dat de modale onderhoudsstaat van de geïnventariseerde elementtypen in $26 \%$ van de gevallen goed en in $74 \%$ van de gevallen redelijk is. Doordat er naar verhouding maar weinig elementen zijn aangetroffen met een matige of slechte onderhoudsstaat, zijn er geen elementtypen met een modale score matig of slecht. Ook de gemiddelde onderhoudsstaat varieert tussen goed en redelijk (Tabel 8).

Nemen we op steekproefniveau alle 39 geïnventariseerde elementtypen samen, dan is de modale onderhoudsstaat redelijk. Hetzelfde geldt voor de eindgemiddelde onderhoudsstaat (Tabel 8).

De variatie in de onderhoudsstaat is relatief groot bij de elementtypen moestuin, bloemperken, hagen (2x snoeien), leifruit, beschoeiing, vaste plantenborders, fruitbomen, zichtassen en zichtlijnen en solitaire bomen en boomgroepen (standaardafwijking 0,83 tot bijna 1 onderhoudsklasse). Binnen deze elementtypen verschillen de geïnventariseerde elementen onderling dus vrij sterk in onderhoudsstaat. Hierdoor is de gemiddelde score voor deze groep eigenaren naar verhouding minder betrouwbaar (Tabel 8). We komen hierop terug in paragraaf 5.1.7.

\subsubsection{Tot besluit}

De modale onderhoudsstaat van het in de steekproef onderzochte groene erfgoed is in zijn geheel genomen redelijk. De gemiddelde score van de onderhoudsstaat is per categorie groen erfgoed, categorie eigenaar, provincie of elementtype steeds goed of redelijk. Toch is er binnen categorieën sprake van (soms aanzienlijke) variatie in onderhoudsstaat. Groenelementen in slechte staat werden nauwelijks aangetroffen ( $3 \%$ ), echter ongeveer $1 / 5$ van alle geïnventariseerde groenelementen scoorde matig. 
De in dit hoofdstuk gepresenteerde cijfers over onderhoudsstaat zijn niet een-op-een te koppelen aan de geleverde onderhoudsinspanning. Om een voorbeeld te noemen: asfaltpaden vragen om een beperktere jaarlijkse onderhoudsinspanning om tot een goede staat te komen dan grindpaden.

Tabel 8 Onderhoudsstaat per type groen element. De tabel is gesorteerd op gemiddelde onderhoudsstaat.

\begin{tabular}{|c|c|c|c|c|c|}
\hline Elementtype & $\frac{\text { 넝 }}{\frac{\pi}{2}}$ & $\frac{5}{\frac{5}{0}}$ & 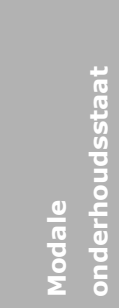 & 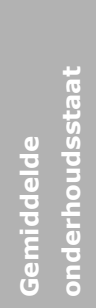 & 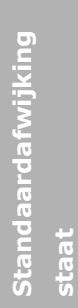 \\
\hline Eenvoudige houten loopbruggetjes & 1 & 182 & goed & 1,39 & 0,71 \\
\hline Paden en wegen (verhard) & 1 & 3.018 & goed & 1,48 & 0,68 \\
\hline Leibomen en knotbomen & 2 & 193 & goed & 1,53 & 0,68 \\
\hline Zichtassen en zichtlijnen & 1 & 128 & goed & 1,68 & 0,84 \\
\hline Bloemperken & geen & 339 & goed & 1,77 & 0,96 \\
\hline Rozenperken & 2 & 626 & redelijk & 1,78 & 0,71 \\
\hline Hagen ( $1 x$ snoeien) & 1 & 4.146 & redelijk & 1,79 & 0,76 \\
\hline Vaste plantenborders & 2 & 1.519 & goed & 1,80 & 0,87 \\
\hline Berceaus & 1 & 56 & redelijk & 1,87 & 0,78 \\
\hline Kuipplanten & 2 & 261 & redelijk & 1,88 & 0,76 \\
\hline Leifruit & 1 & 143 & goed & 1,93 & 0,91 \\
\hline Heesterborders & 1 & 1.975 & redelijk & 1,94 & 0,78 \\
\hline Aardwerken & 1 & 39 & redelijk & 1,95 & 0,69 \\
\hline Parkbosrand & 1 & 1.363 & redelijk & 1,96 & 0,72 \\
\hline Hagen ( $2 x$ snoeien) & 1 & 892 & goed & 1,96 & 0,93 \\
\hline Beschoeiing & 1 & 414 & goed & 1,96 & 0,89 \\
\hline Hakhout & 2 & 158 & redelijk & 1,98 & 0,45 \\
\hline Gazons & 1 & 4.317 & redelijk & 1,98 & 0,70 \\
\hline Klimplanten & 2 & 304 & redelijk & 1,99 & 0,77 \\
\hline Heestergroepen & 1 & 2.423 & redelijk & 1,99 & 0,77 \\
\hline Paden en wegen (half-/onverhard) & 1 & 7.378 & redelijk & 2,05 & 0,75 \\
\hline Topiaria & 1 & 729 & redelijk & 2,05 & 0,81 \\
\hline Solitaire bomen en boomgroepen & 1 & 5.685 & redelijk & 2,05 & 0,83 \\
\hline Moestuin & geen & 486 & redelijk & 2,07 & 0,97 \\
\hline Houtwal en houtsingel & geen & 491 & redelijk & 2,08 & 0,62 \\
\hline Parkbos & 2 & 4.242 & redelijk & 2,14 & 0,64 \\
\hline Parkweiden & 1 & 2.233 & redelijk & 2,15 & 0,72 \\
\hline Laanbomen & 1 & 5.248 & redelijk & 2,17 & 0,75 \\
\hline Paden (gras) & 1 & 1.350 & redelijk & 2,19 & 0,75 \\
\hline Bermen & 1 & 2.898 & redelijk & 2,21 & 0,65 \\
\hline Gras langs waterlopen & 1 & 5.519 & redelijk & 2,22 & 0,55 \\
\hline Waterpartijen en waterlopen & 1 & 4.207 & redelijk & 2,23 & 0,75 \\
\hline Fruitbomen & 1 & 678 & redelijk & 2,29 & 0,86 \\
\hline Boomsingel & 1 & 410 & redelijk & 2,32 & 0,68 \\
\hline Ruigten in parkbos & 1 & 258 & redelijk & 2,39 & 0,75 \\
\hline Eindtotaal & & 64.308 & redelijk & 2,02 & 0,76 \\
\hline
\end{tabular}




\subsection{Extrapolatie van steekproef naar heel Nederland}

De gegevens die in het kader van de steekproef in het veld zijn verzameld, vormen de basis voor de extrapolatie naar de hele populatie rijksbeschermd groen erfgoed in Nederland. Hoe deze extrapolatie is uitgevoerd, is beschreven in paragraaf 3.6. Van belang is dat in de extrapolatie is gewerkt met gegevens op objectniveau.

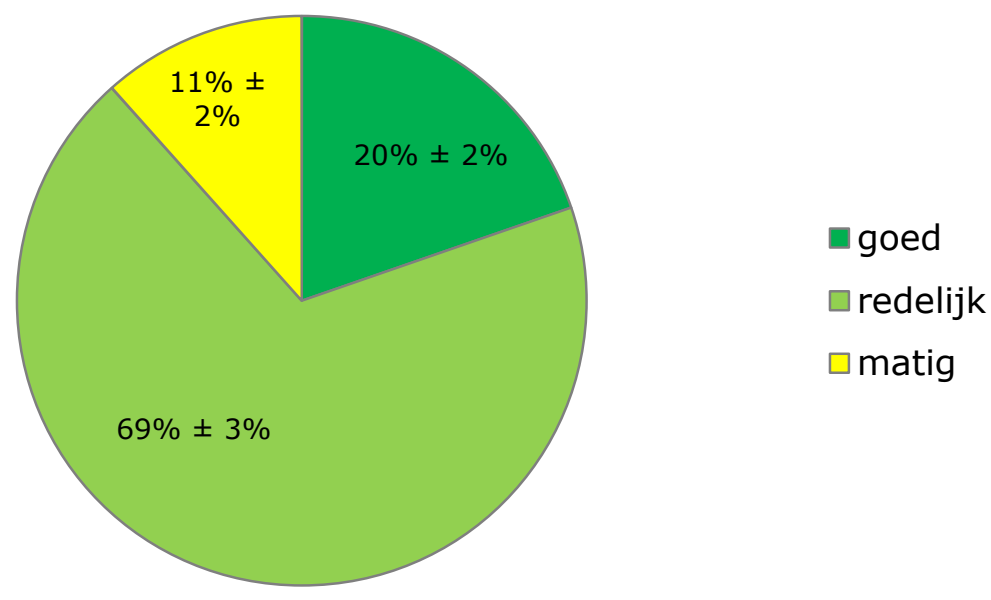

Figuur 6 Onderhoudsstaat ( \pm standaardafwijking) van de rijksmonumenten met beschermde groenaanleg in Nederland. Deze objectieve schatting is gebaseerd op de modale onderhoudsstaat per object uit de steekproef.

Figuur 6 laat zien dat 20\% van de rijksbeschermde groenaanleggen in Nederland een onderhoudsstaat goed heeft en bijna $70 \%$ een onderhoudsstaat redelijk. Voor $89 \%$ van de objecten in de populatie geldt dus dat hun onderhoudsstaat minimaal redelijk is. In $11 \%$ van de objecten is de onderhoudsstaat matig.

In Figuur 7 worden deze resultaten uitgesplitst naar categorie groen erfgoed. De volgorde waarin de categorieën worden gepresenteerd, komt overeen met hun gemiddelde onderhoudsstaat op steekproefniveau (Tabel 5).

Figuur 7 laat zien dat volgens de objectieve schatting in sommige categorieën groen erfgoed in Nederland geen objecten voorkomen met een matige onderhoudsstaat. Dit geldt voor groenaanleg bij medische en sociale instellingen, voor stadstuinen, collectietuinen en de categorie diversen. Daar staat tegenover dat in de categorieën pastorietuinen, tuinen en parken bij landhuizen en tuinen bij bedrijven, overheid en organisaties naar schatting een kwart tot de helft van de objecten in Nederland een matige onderhoudsstaat heeft.

Hoewel de categorie groen erfgoed als stratificatievariabele is meegenomen in het steekproefontwerp, moet bij het voorgaande worden aangetekend dat deze schattingen in veel gevallen zijn gebaseerd op relatief kleine aantallen objecten in de steekproef (variërend van twee collectietuinen tot acht stadstuinen). Dit maakt de schattingen voor categorieën als collectietuinen, pastorietuinen, tuinen bij bedrijven, overheid en organisaties, erven en diversen minder betrouwbaar dan de schattingen voor grote categorieën, zoals begraafplaatsen en groenaanleg bij buitenplaatsen \& landgoederen. 
Groenaanleg bij medische en Stadstuinen (55) sociale instellingen (48)
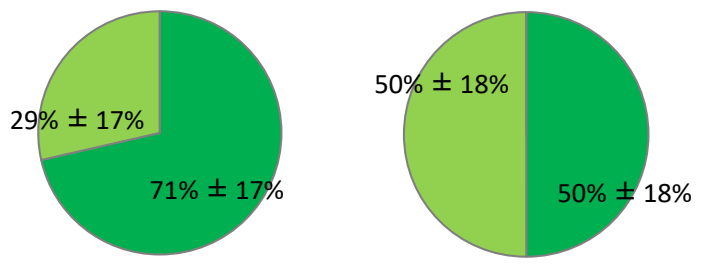

Tuinen bij bedrijven, overheid Groenaanleg bij en organisaties (26) religieuze gebouwen (59)
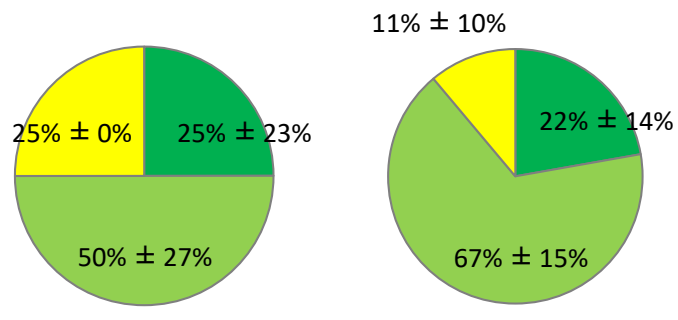

Tuinen en parken

Collectietuinen (9) bij landhuizen (40)
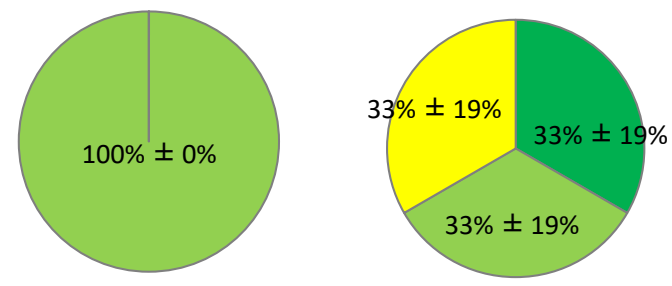

Erven (32)

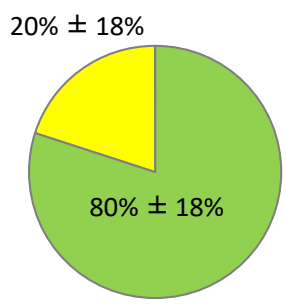

Villatuinen (99)

Diversen (30)

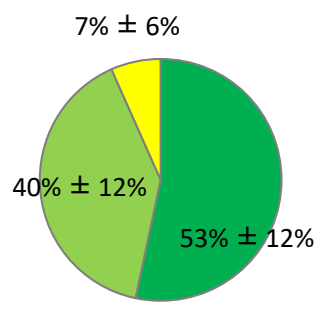

Stadsparken en
plantsoenen (67)

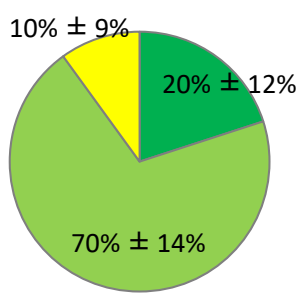

Groenaanleg bij buitenplaatsen \& landgoederen (569)
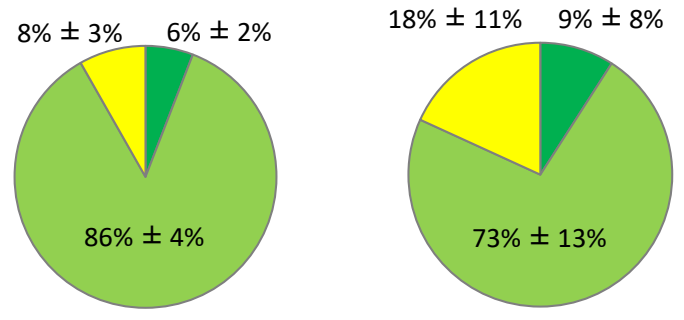

Figur 7 Geschatte onderhoudsstaat ( \pm standaardafwijking van het percentage) van elk van de onderscheiden categorieën groen erfgoed in Nederland. De schatting is gebaseerd op de modale onderhoudsstaat per object uit de steekproef. Per categorie groen erfgoed staat het aantal objecten in Nederland tussen haakjes. 


\section{Onderhoudskosten groen erfgoed}

In dit hoofdstuk presenteren we een overzicht van de onderhoudskosten van rijksbeschermd groen erfgoed. Het gaat om schattingen van de jaarlijkse gemiddelde kosten, bepaald op basis van de 209 geïnventariseerde objecten (paragraaf 5.1). Op basis van deze resultaten is ook een schatting gemaakt van de jaarlijkse gemiddelde onderhoudskosten voor alle groene rijksmonumenten in Nederland (paragraaf 5.2).

\subsection{Resultaten op steekproefniveau}

De totale jaargemiddelde onderhoudskosten van de 209 geïnventariseerde objecten uit de steekproef bedragen ongeveer $€ 20$ miljoen (Tabel 9). Zowel voor dit bedrag als voor onderhoudskosten gepresenteerd in paragraaf 5.1.1 t/m paragraaf 5.1.6 geldt dat de kosten steeds zijn berekend uitgaande van frequenties voor sober en doelmatig onderhoud volgens de Leidraad subsidiabele instandhoudingskosten 2013. Ook zijn de bedragen steeds inclusief 38\% indirecte kosten, waaronder btw. (Zie voor de samenstelling van de indirecte kosten paragraaf 3.5.3.) In paragraaf 5.1.5 gaan we in op de meerkosten uitgaande van afwijkende frequenties voor sober en doelmatig onderhoud gebaseerd op deskundigenoordeel.

\subsubsection{Verschillen tussen categorieën groen erfgoed}

Tabel 9 toont in afnemende volgorde de totale jaarlijkse onderhoudskosten voor de diverse categorieën groen erfgoed. De totale kosten zijn veruit het hoogst (ruim $€ 15,4$ miljoen) in de categorie groenaanleg bij buitenplaatsen en landgoederen. Dit kan worden verklaard doordat dit met ongeveer een derde van alle objecten het grootste stratum in de steekproef is. Bovendien gaat het in veel gevallen om relatief grote objecten vergeleken met veel van de andere categorieën groen erfgoed. Iets soortgelijks geldt voor de stadsparken en plantsoenen (in totaal ca. $€ 1,5$ miljoen onderhoudskosten op jaarbasis) en de begraafplaatsen (iets minder dan $€ 1$ miljoen). Aan de andere kant zijn de totale jaarlijkse onderhoudskosten relatief laag (minder dan $€ 150.000$ ) voor stadstuinen, pastorietuinen, collectietuinen, erven en boerentuinen en -erven. In deze gevallen gaat het veelal om relatief kleine objecten en is ook het aantal objecten in deze categorieën gering.

Tabel 9 Onderhoudskosten per categorie groen erfgoed.*

\begin{tabular}{lrr} 
Categorie groen erfigoed & Aantal objecten & Totale kosten per jaar \\
Groenaanleg bij buitenplaatsen \& landgoederen & 85 & $€ 15.433 .578$ \\
\hline Stadsparken en plantsoenen & 10 & $€ 1.510 .267$ \\
\hline Begraafplaatsen & 38 & $€ 917.289$ \\
\hline Groenaanleg bij religieuze gebouwen & 9 & $€ 364.041$ \\
\hline Diversen & 5 & $€ 320.437$ \\
\hline Villatuinen & 15 & $€ 271.955$ \\
\hline Tuinen bij bedrijven, overheid en organisaties & 4 & $€ 183.682$ \\
\hline Groenaanleg bij medische en sociale instellingen & 7 & $€ 172.073$ \\
\hline Tuinen en parken bij landhuizen & 6 & $€ 164.220$ \\
\hline Boerentuinen en boerenerven & 11 & $€ 128.171$ \\
\hline Erven & 5 & $€ 126.341$ \\
\hline Collectietuinen & 2 & $€ 91.019$ \\
\hline Pastorietuinen & 4 & $€ 43.707$ \\
\hline Stadstuinen & 8 & $€ 34.707$ \\
\hline Eindtotaal & 209 & $€ 19.761 .486$ \\
\hline * Bij onderhoudsfrequenties voor sober en doelmatig onderhoud volgens de Leidraad subsidiabele instandhoudingskosten 2013.
\end{tabular}


Wanneer we de resultaten uit Tabel 9 uitdrukken per object volgen daaruit voor de verschillende categorieën groen erfgoed in afnemende volgorde de gemiddelde jaarlijkse kosten per object zoals weergegeven in Tabel 10. De twee koplopers uit Tabel 9 staan in Tabel 10 nog steeds bovenaan en de twee hekkensluiters nog steeds onderaan. Dit kan worden verklaard door hun relatief grote, respectievelijk relatief kleine gemiddelde omvang. Welke elementtypen aanwezig zijn in een object is een andere factor die de hoogte van de onderhoudskosten bepaalt. Collectietuinen zijn gemiddeld per object relatief duur (Tabel 10), maar door het geringe aantal objecten in de steekproef is hun aandeel in de totale jaarlijkse onderhoudskosten gering (Tabel 9).

Tabel 10 toont per categorie groen erfgoed niet alleen de gemiddelde onderhoudskosten per object, maar ook wat binnen elke categorie de laagste en de hoogste kosten per object zijn. Dan worden grote verschillen in jaarlijkse kosten per object zichtbaar, vooral in de categorieën groenaanleg bij buitenplaatsen en landgoederen, stadsparken en plantsoenen en begraafplaatsen. Dit wordt in belangrijke mate verklaard door de relatief grote variatie in omvang van de objecten in deze categorieën groen erfgoed.

Tabel 10 Onderhoudskosten per object, per categorie groen erfgoed.*

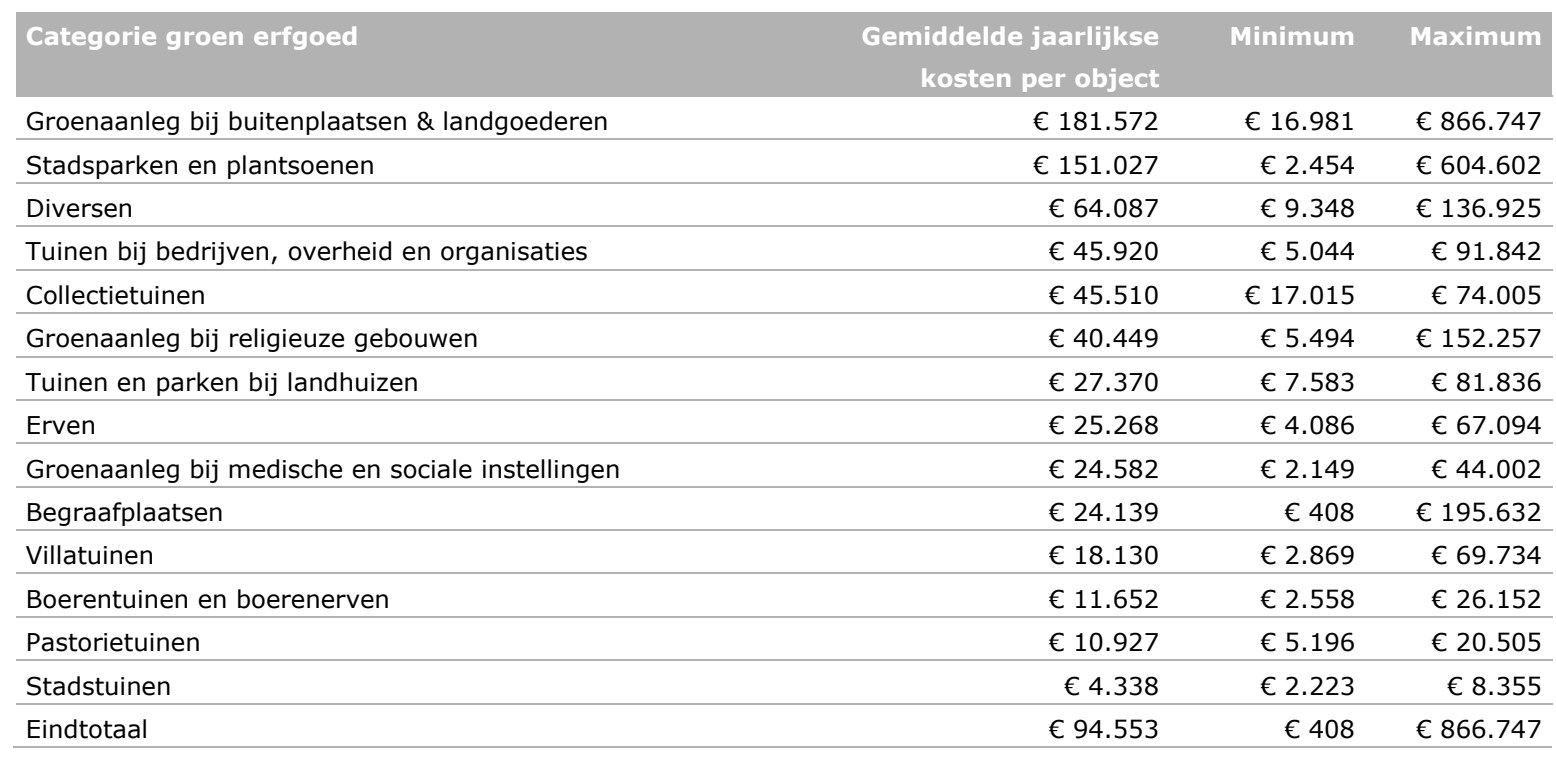

* Bij onderhoudsfrequenties voor sober en doelmatig onderhoud volgens de Leidraad subsidiabele instandhoudingskosten 2013.

\subsubsection{Verschillen tussen categorieën eigenaren}

Tabel 11 en Tabel 12 tonen de jaarlijkse onderhoudskosten per categorie eigenaar. Bijna de helft van de objecten in de steekproef is in particuliere handen, waardoor deze categorie de hoogste totale onderhoudskosten heeft. Qua jaarlijkse totale kosten komen de terreinbeherende organisaties op de tweede plaats, hoewel ze maar $11 \%$ van de objecten in de steekproef in eigendom hebben. Tabel 12 laat zien dat dit kan worden verklaard door de gemiddelde kosten per object, die bij de terreinbeherende organisaties veel hoger zijn dan bij de overige categorieën eigenaar. Zo ligt de ondergrens van de range aan onderhoudskosten bij de terreinbeherende organisaties veel hoger dan bij de andere categorieën eigenaren. Dit komt doordat op één na alle objecten van terreinbeherende organisaties in de categorie groenaanleg bij buitenplaatsen \& landgoederen vallen. De ene uitzondering is een villatuin (Tabel 13). De terreinbeherende organisaties beheren naar verhouding relatief grote objecten. Zoals in de vorige paragraaf genoemd, is ook hier van belang dat de onderhoudskosten niet alleen worden bepaald door de omvang van de objecten, maar ook door de aanwezige elementtypen. Bij de overige categorieën eigenaar zijn de objecten verdeeld over meer categorieën groen erfgoed en dit in de sterkste mate bij erfgoed in particuliere handen. De erfgoed beherende instellingen hebben het kleinste aandeel in de totale kosten, maar niet het kleinste aandeel in het aantal objecten (Tabel 11). Dit wordt verklaard doordat ongeveer de helft van de objecten begraafplaatsen zijn (Tabel 13), met relatief minder hoge onderhoudskosten (Tabel 10). 
Tabel 11 Onderhoudskosten per categorie eigenaar.*

\begin{tabular}{lrr} 
Categorie eigenaren & Aantal objecten & Totale kosten per jaar \\
Erfgoed in particuliere handen & 98 & $€ 8.047 .893$ \\
\hline Terreinbeherende organisaties & 24 & $€ 5.897 .704$ \\
\hline Erfgoed in publieke handen & 39 & $€ 3.877 .265$ \\
\hline Erfgoed beherende instellingen & 48 & $€ 1.938 .624$ \\
\hline Eindtotaal & 209 & $€ 19.761 .486$
\end{tabular}

* Bij onderhoudsfrequenties voor sober en doelmatig onderhoud volgens de Leidraad subsidiabele instandhoudingskosten 2013.

Tabel 12 Onderhoudskosten per object, per categorie eigenaar.*

\begin{tabular}{lrrr} 
Categorie eigenaar & Gemiddelde jaarlijkse kosten per object & Minimum & Maximum \\
Terreinbeherende organisaties & $€ 245.738$ & $€ 33.948$ & $€ 828.804$ \\
\hline Erfgoed in publieke handen & $€ 99.417$ & $€ 2.454$ & $€ 604.602$ \\
\hline Erfgoed in particuliere handen & $€ 82.121$ & $€ 408$ & $€ 866.747$ \\
\hline Erfgoed beherende instellingen & $€ 40.388$ & $€ 462$ & $€ 368.408$ \\
\hline Eindtotaal & $€ 94.553$ & $€ 408$ & $€ 866.747$ \\
\hline
\end{tabular}

* Bij onderhoudsfrequenties voor sober en doelmatig onderhoud volgens de Leidraad subsidiabele instandhoudingskosten 2013.

Tabel 13 Aantal geïnventariseerde objecten per categorie eigenaar en categorie groen erfgoed.

\begin{tabular}{|c|c|c|c|c|c|}
\hline Categorie groen erfgoed & 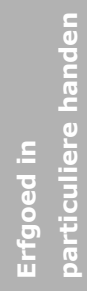 & 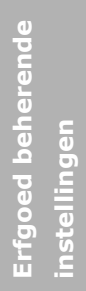 & 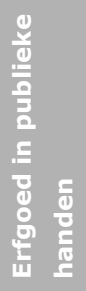 & 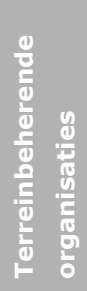 & 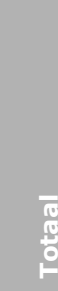 \\
\hline Groenaanleg bij buitenplaatsen \& landgoederen & 46 & 5 & 11 & 23 & 85 \\
\hline Begraafplaatsen & 2 & 25 & 11 & & 38 \\
\hline Villatuinen & 12 & & 2 & 1 & 15 \\
\hline Boerentuinen en boerenerven & 11 & & & & 11 \\
\hline Stadsparken en plantsoenen & & & 10 & & 10 \\
\hline Groenaanleg bij medische en sociale instellingen & 2 & 3 & 2 & & 7 \\
\hline Tuinen en parken bij landhuizen & 6 & & & & 6 \\
\hline Diversen & 1 & 2 & 2 & & 5 \\
\hline Erven & 4 & & 1 & & 5 \\
\hline Pastorietuinen & 1 & 3 & & & 4 \\
\hline Tuinen bij bedrijven, overheid en organisaties & 3 & 1 & & & 4 \\
\hline Collectietuinen & & 2 & & & 2 \\
\hline Totaal & 98 & 48 & 39 & 24 & 209 \\
\hline
\end{tabular}




\subsubsection{Verschillen tussen provincies}

Tabel 14 laat de jaarlijkse onderhoudskosten per provincie zien en Tabel 17 toont per provincie de verdeling van de objecten over de categorieën eigenaren. Tabel 15 laat niet alleen de gemiddelde onderhoudskosten per object zien, maar ook wat binnen elke provincie de laagste en de hoogste kosten per object zijn. Gelderland, Utrecht en Noord-Holland kennen de hoogste jaarlijkse onderhoudskosten voor rijksbeschermd groen erfgoed. Deze provincies herbergen samen $41 \%$ van alle objecten in de steekproef. Maar ook als we de onderhoudskosten uitdrukken per object, staan deze drie provincies qua kosten bovenaan. Dit komt doordat de twee categorieën groen erfgoed die in onderhoud het duurst zijn (Tabel 10) in deze drie provincies oververtegenwoordigd zijn: de helft van de stadsparken en plantsoenen en meer dan de helft van de buitenplaatsen en landgoederen uit de steekproef liggen in Gelderland, Utrecht en Noord-Holland (Tabel 16).

Tabel 14 Onderhoudskosten per provincie.*

\begin{tabular}{lrr} 
Provincie & Aantal objecten & Totale kosten per jaar \\
Gelderland & 36 & $€ 5.066 .445$ \\
\hline Utrecht & 26 & $€ 3.842 .584$ \\
\hline Noord-Holland & 24 & $€ 2.728 .670$ \\
\hline Noord-Brabant & 30 & $€ 1.804 .849$ \\
\hline Zuid-Holland & 24 & $€ 1.533 .287$ \\
\hline Friesland & 16 & $€ 1.465 .450$ \\
\hline Overijssel & 12 & $€ 1.332 .550$ \\
\hline Limburg & 15 & $€ 871.766$ \\
\hline Groningen & 10 & $€ 575.889$ \\
\hline Drenthe & 8 & $€ 322.124$ \\
\hline Zeeland & 8 & $€ 217.871$ \\
\hline Eindtotaal & 209 & $€ 19.761 .486$ \\
\hline
\end{tabular}

* Bij onderhoudsfrequenties voor sober en doelmatig onderhoud volgens de Leidraad subsidiabele instandhoudingskosten 2013.

Tabel 15 Onderhoudskosten per object, per provincie.*

\begin{tabular}{lrrr} 
Provincie & $\begin{array}{r}\text { Gemiddelde jaarlijkse } \\
\text { kosten per object }\end{array}$ & Minimum & Maximum \\
Utrecht & $€ 147.792$ & $€ 3.068$ & $€ 866.747$ \\
\hline Gelderland & $€ 140.735$ & $€ 824$ & $€ 690.586$ \\
\hline Noord-Holland & $€ 113.695$ & $€ 2.149$ & $€ 604.602$ \\
\hline Overijssel & $€ 111.046$ & $€ 1.395$ & $€ 536.878$ \\
\hline Friesland & $€ 91.591$ & $€ 1.503$ & $€ 368.408$ \\
\hline Zuid-Holland & $€ 63.887$ & $€ 789$ & $€ 364.865$ \\
\hline Noord-Brabant & $€ 60.162$ & $€ 2.223$ & $€ 422.246$ \\
\hline Limburg & $€ 58.118$ & $€ 408$ & $€ 152.257$ \\
\hline Groningen & $€ 57.589$ & $€ 462$ & $€ 238.621$ \\
\hline Drenthe & $€ 40.266$ & $€ 958$ & $€ 157.034$ \\
\hline Zeeland & $€ 27.234$ & $€ 1.101$ & $€ 79.259$ \\
\hline Eindtotaal & $€ 94.553$ & $€ 408$ & $€ 866.747$ \\
\hline
\end{tabular}

* Bij onderhoudsfrequenties voor sober en doelmatig onderhoud volgens de Leidraad subsidiabele instandhoudingskosten 2013. 
Tabel 16 Aantal geïnventariseerde objecten per provincie en categorie groen erfgoed.

\begin{tabular}{|c|c|c|c|c|c|c|c|c|c|c|c|c|}
\hline Categorie groen erfgoed & 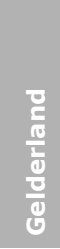 & 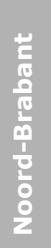 & $\begin{array}{l}\text { 흥 } \\
\text { 힌 }\end{array}$ & $\begin{array}{l}\frac{7}{0} \\
\frac{1}{10} \\
\overline{0} \\
\frac{0}{1} \\
\frac{1}{0} \\
\frac{1}{2} \\
\frac{0}{2}\end{array}$ & 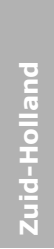 & $\frac{\mathrm{T}}{\frac{\mathrm{C}}{\mathrm{c}}}$ & $\begin{array}{l}\text { 인 } \\
\text { 멸 } \\
\text { 톨 }\end{array}$ & $\begin{array}{l}\overline{0} \\
\overline{5} \\
\frac{3}{0} \\
0 \\
0\end{array}$ & 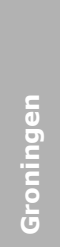 & 흘 & एँ & $\begin{array}{l}\text { 롱 } \\
\text { 음 }\end{array}$ \\
\hline Groenaanleg bij buitenplaatsen \& landgoederen & 19 & 7 & 16 & 9 & 8 & 6 & 7 & 4 & 2 & 3 & 4 & 85 \\
\hline Begraafplaatsen & 8 & 1 & 1 & 5 & 5 & 6 & 3 & 4 & 2 & 1 & 2 & 38 \\
\hline Villatuinen & 1 & 5 & 5 & 1 & & & 1 & & 1 & 1 & & 15 \\
\hline Boerentuinen en boerenerven & 1 & 3 & & 2 & 2 & 1 & & 1 & 1 & & & 11 \\
\hline Stadsparken en plantsoenen & 1 & 1 & 1 & 3 & 1 & 1 & & 1 & 1 & & & 10 \\
\hline Groenaanleg bij religieuze gebouwen & & 6 & & 1 & & & 1 & & 1 & & & 9 \\
\hline Stadstuinen & 1 & 3 & 2 & & & & & & & 1 & 1 & 8 \\
\hline Groenaanleg bij medische en sociale instellingen & 1 & 1 & & 1 & 2 & 1 & 1 & & & & & 7 \\
\hline Tuinen en parken bij landhuizen & 2 & 1 & & & 2 & & 1 & & & & & 6 \\
\hline Diversen & 2 & & & 1 & & & & & 2 & & & 5 \\
\hline Erven & & 1 & & & 1 & & 1 & 1 & & 1 & & 5 \\
\hline Pastorietuinen & & 1 & & & 1 & 1 & & & & & 1 & 4 \\
\hline Tuinen bij bedrijven, overheid en organisaties & & & & 1 & 1 & & & 1 & & 1 & & 4 \\
\hline Collectietuinen & & & 1 & & 1 & & & & & & & 2 \\
\hline Totaal & 36 & 30 & 26 & 24 & 24 & 16 & 15 & 12 & 10 & 8 & 8 & 209 \\
\hline
\end{tabular}

Tabel 17 Aantal geïnventariseerde objecten per categorie eigenaar en provincie.

\begin{tabular}{|c|c|c|c|c|c|}
\hline Provincie & 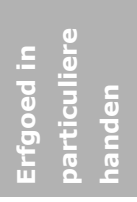 & 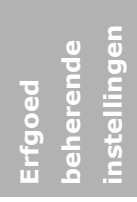 & 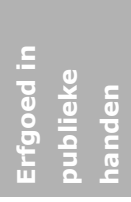 & 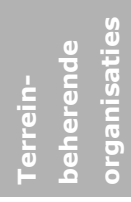 & 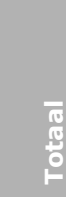 \\
\hline Gelderland & 16 & 8 & 5 & 7 & 36 \\
\hline Noord-Brabant & 13 & 8 & 5 & 4 & 30 \\
\hline Utrecht & 19 & 2 & 4 & 1 & 26 \\
\hline Noord-Holland & 6 & 4 & 10 & 4 & 24 \\
\hline Zuid-Holland & 10 & 7 & 7 & & 24 \\
\hline Friesland & 6 & 8 & 2 & & 16 \\
\hline Limburg & 9 & 3 & & 3 & 15 \\
\hline Overijssel & 5 & 4 & 2 & 1 & 12 \\
\hline Groningen & 6 & 2 & 2 & & 10 \\
\hline Drenthe & 4 & 1 & & 3 & 8 \\
\hline Zeeland & 4 & 1 & 2 & 1 & 8 \\
\hline Eindtotaal & 98 & 48 & 39 & 24 & 209 \\
\hline
\end{tabular}




\subsubsection{Verschillen tussen elementtypen}

In deze paragraaf geven we een overzicht van de onderhoudskosten per beschouwd elementtype. De bedragen in deze paragraaf hebben betrekking op de 209 onderzochte objecten in de steekproef.

Tabel 18 Onderhoudskosten per elementtype en per eenheid oppervlakte.*

\begin{tabular}{|c|c|c|c|c|}
\hline \multirow[t]{2}{*}{ Elementtype } & \multirow[t]{2}{*}{ Totale kosten/jaar } & \multirow{2}{*}{$\begin{array}{r}\text { Totaal } \\
\text { oppervlak (ha) }\end{array}$} & \multirow{2}{*}{$\begin{array}{r}\text { Totale } \\
\text { kosten/ha/jaar }\end{array}$} & \multirow[t]{2}{*}{ Totale kosten $/ \mathrm{m}^{2} / \mathrm{jaar}$} \\
\hline & & & & \\
\hline Paden (on-/halfverhard) & $€ 4.347 .963$ & 282,9 & $€ 15.372$ & $€ 1,54$ \\
\hline Waterpartijen en waterlopen & $€ 1.924 .527$ & 409,9 & $€ 4.695$ & $€ 0,47$ \\
\hline Parkweiden & $€ 1.886 .114$ & 487,2 & $€ 3.871$ & $€ 0,39$ \\
\hline Heesterborder & $€ 753.498$ & 13,9 & $€ 54.354$ & $€ 5,44$ \\
\hline Gazons & $€ 737.973$ & 179,3 & $€ 4.116$ & $€ 0,41$ \\
\hline Bermen & $€ 412.518$ & 131,5 & $€ 3.137$ & $€ 0,31$ \\
\hline Rozenperken & $€ 144.385$ & 0,8 & $€ 191.242$ & $€ 19,12$ \\
\hline Aardwerken & $€ 13.122$ & 3,6 & $€ 3.695$ & $€ 0,37$ \\
\hline Berceaus & $€ 8.267$ & 0,4 & $€ 20.652$ & $€ 2,07$ \\
\hline Totaal & $€ 14.321 .610$ & & & \\
\hline
\end{tabular}

* Bij sober en doelmatig onderhoud volgens de Leidraad subsidiabele instandhoudingskosten 2013.

Tabel 19 Onderhoudskosten per elementtype en per eenheid lengte.*

\begin{tabular}{lrrr} 
Elementtype & Totale kosten/jaar & Totale lengte $\left(\mathrm{m}^{1}\right)$ & Totale kosten/m $^{1} / \mathrm{jaar}$ \\
Beschoeiing & $€ 1.336 .429$ & 208.207 & \\
\hline Gras langs waterlopen & $€ 635.393$ & 554.359 & \\
\hline Hagen (1x snoeien) & $€ 473.689$ & 84.568 & 1,15 \\
\hline Parkbosrand & $€ 240.732$ & 126.233 & 24.600 \\
\hline Zichtassen en zichtlijnen & $€ 123.354$ & 11.496 & $€ 5,01$ \\
\hline Hagen (2x snoeien) & $€ 64.317$ & & $€ 5,59$ \\
\hline Totaal & $€ 2.873 .914$ & & \\
\hline
\end{tabular}

* Bij sober en doelmatig onderhoud volgens de Leidraad subsidiabele instandhoudingskosten 2013.

In lijn met de voorgaande paragrafen bedragen de totale jaargemiddelde onderhoudskosten voor de onderzochte groene elementtypen op steekproefniveau $€$ 19.761.486 (som van de totalen uit Tabel 18, Tabel 19 en Tabel 20).

Op basis van hun totale omvang zijn er zeven elementtypen die op steekproefniveau elk afzonderlijk boven een miljoen euro aan jaargemiddelde onderhoudskosten uitkomen. Dit zijn, in volgorde van afnemende kosten (Tabel 18, Tabel 19 en Tabel 20): paden (onverhard of half-verhard), laanbomen, paden (verhard), waterpartijen en waterlopen, parkweiden, beschoeiing en vaste plantenborders. Samen nemen deze elementtypen driekwart van de totale onderhoudskosten op steekproefniveau voor hun rekening.

Tabel 18, Tabel 19 en Tabel 20 laten ook de onderhoudskosten zien van de diverse elementtypen uitgedrukt per eenheid oppervlakte, lengte of aantal. Dan valt op dat deels andere elementtypen naar voren komen met relatief hoge onderhoudskosten per eenheid oppervlakte, lengte of aantal. Voorbeelden zijn rozenperken, leifruit, kuipplanten, eenvoudige loopbruggetjes en fruitbomen. Dit komt doordat deze elementtypen qua omvang een relatief bescheiden aandeel hebben in de steekproef als geheel. In individuele objecten kunnen deze elementtypen wel relatief sterk doorwegen in de onderhoudskosten. 
Tabel 20 Onderhoudskosten per elementtype en per stuk. *

\begin{tabular}{|c|c|c|c|c|}
\hline Elementtype & Totale kosten/jaar & $\begin{array}{r}\text { Totaal aantal } \\
\text { (stuks) }\end{array}$ & $\begin{array}{r}\text { Totale } \\
\text { kosten/st/jaar }\end{array}$ & \\
\hline Laanbomen & $€ 1.957 .200$ & 85073 & $€ 23,01$ & $* *$ \\
\hline Fruitbomen & $€ 119.891$ & 2144 & $€ 55,92$ & \\
\hline Leifruit & $€ 77.266$ & 716 & $€ 107,91$ & \\
\hline Topiaria & $€ 41.837$ & 1509 & $€ 27,72$ & \\
\hline Bomen in boomsingel & $€ 20.428$ & 7967 & $€ 2,56$ & $* *$ \\
\hline Leibomen en knotbomen & $€ 15.411$ & 592 & $€ 26,03$ & \\
\hline Eenvoudige loopbruggetjes & $€ 12.124$ & 170 & $€ 71,32$ & \\
\hline
\end{tabular}

* Bij sober en doelmatig onderhoud volgens de Leidraad subsidiabele instandhoudingskosten 2013.

**Aanname plantafstanden: 1 boom per 5 m boomsingel en 1 boom per 4 m laanbomenrij en $10 \%$ uitval laanbomen.

\subsubsection{Onderhoudskosten bij afwijkende onderhoudsfrequenties}

Bij de kostenberekening is op grond van deskundigenoordeel per elementtype ingeschat of het voor sober en doelmatig onderhoud nodig is de onderhoudsfrequenties uit de Leidraad te verhogen (Bijlage 2). Het resultaat hiervan is een parallelle set van onderhoudskosten, naast de kosten uitgaande van onderhoudsfrequenties volgens de Leidraad.

Wanneer we de jaarlijkse onderhoudskosten (incl. indirecte kosten en btw) berekenen op basis van afwijkende frequenties voor sober en doelmatig onderhoud, worden de kosten $41 \%$ hoger dan bij onderhoudsfrequenties volgens de Leidraad. Van deze meerkosten bij afwijkende onderhoudsfrequenties voor sober en doelmatig beheer komt $65 \%$ voor rekening van het elementtype gazon (Bijlage 5).

Of en in welke mate we voor sober en doelmatig onderhoud zijn afgeweken van de onderhoudsfrequenties volgens de Leidraad, verschilt per elementtype (zie Bijlage 2). Ook verschillen de objecten onderling in aanwezigheid en omvang van de diverse elementtypen. Hierdoor is bij elk van de 209 onderzochte objecten de verhouding tussen de onderhoudskosten bij afwijkende frequentie en de onderhoudskosten bij frequentie volgens Leidraad anders. Daardoor verschilt deze verhouding ook tussen de categorieën groen erfgoed, categorieën eigenaar en provincies. Bijlage 5 laat zien waar deze verschillen zitten.

\subsubsection{Onderscheid tussen prioriteit 1 en 2}

De jaarlijkse onderhoudskosten (incl. indirecte kosten en btw) van elementtypen met prioriteit 2 bedragen $7 \%$ van de totale jaarlijkse onderhoudskosten (prioriteit $1+2$ ) (Bijlage 5 ). Als we uitgaan van afwijkende frequenties voor sober en doelmatig onderhoud, bedraagt het aandeel van elementtypen met prioriteit 2 in de totale jaarlijkse onderhoudskosten $5 \%$. Dit lagere percentage voor het aandeel van elementtypen met prioriteit 2 komt doordat de meeste elementtypen waarbij afwijkende onderhoudsfrequenties zijn gehanteerd prioriteit 1 hebben.

Het aandeel in de totale jaarlijkse onderhoudskosten dat voor rekening komt van elementtypen met prioriteit 2 verschilt van object tot object. Immers, de objecten verschillen onderling in de mate waarin elementen met prioriteit 2 aanwezig zijn. Daardoor verschilt dit aandeel ook tussen de categorieën groen erfgoed, categorieën eigenaar en provincies. Bijlage 5 laat zien waar deze verschillen zitten. Opvallend is dat bij de collectietuinen, villatuinen en pastorietuinen de onderhoudskosten van elementtypen met prioriteit 2 relatief zwaar wegen ten opzichte van de onderhoudskosten van elementtypen met prioriteit 1 (variërend van $52 \%$ bij pastorietuinen tot $176 \%$ bij collectietuinen). 


\subsubsection{Onderhoudskosten vergeleken met onderhoudsstaat}

Zijn elementtypen of objecten die in gemiddeld slechtere staat zijn duurder in onderhoud? We hebben dit onderzocht op het niveau van elementtypen en van objecten.

Op het niveau van elementtypen lijkt geen sprake van een slechtere onderhoudsstaat bij duurdere elementen. Als we in Tabel 8 de tien elementtypen beschouwen met de slechtste gemiddelde onderhoudsstaat en we gaan na wat hun onderhoudskosten zijn per $\mathrm{m}^{2}$ (Tabel 18), per $\mathrm{m}^{1}$ (Tabel 19) of per stuk (Tabel 20), dan blijkt dat de elementtypen met de slechtste onderhoudsstaat in vrijwel alle gevallen relatief goedkoop zijn in onderhoud. Omgekeerd scoren elementtypen met relatief hoge onderhoudskosten per $\mathrm{m}^{2}$, per $\mathrm{m}^{1}$ of per stuk betrekkelijk goed qua onderhoudsstaat. Voorbeelden hiervan zijn vaste plantenborders, rozenperken, beschoeiing, hagen (1x snoeien), kuipplanten en leifruit (Tabel 8). Hierbij moet wel een kanttekening worden gemaakt. In paragraaf 4.1.5 zagen we al dat de standaardafwijking van de onderhoudsstaat relatief groot is bij de elementtypen moestuin, bloemperken, hagen (2x snoeien), leifruit, beschoeiing, vaste plantenborders, fruitbomen, zichtassen en zichtlijnen en solitaire bomen en boomgroepen (Tabel 8). Ondanks hun goede gemiddelde score zijn er juist bij deze relatief dure elementtypen naar verhouding dus veel individuele elementen met een minder goede onderhoudsstaat.

Conform verwachting wordt dit beeld bevestigd als we de onderhoudsstaat niet uitdrukken in een gemiddelde, maar als procentuele verdeling van de vier klassen van onderhoudsstaat. In Figuur 8 zijn de elementtypen gerangschikt naar oplopende kosten per $\mathrm{m}^{2}, \mathrm{~m}^{1}$ of stuk. In deze volgorde zien we geen eenduidige verandering in de verhouding tussen de verschillende klassen onderhoudsstaat. Het aandeel goed neemt niet duidelijk af en het aandeel matig of slecht neemt niet duidelijk toe.

Figuur 8 laat overigens duidelijk zien hoe verschillend de verhoudingen tussen de verschillende klassen onderhoudsstaat van elementtype tot elementtype kunnen zijn. Het grootste percentage elementen in goede staat en het kleinste aandeel in matige of slechte staat vinden we bij eenvoudige houten loopbruggetjes, verharde paden en wegen en lei- en knotbomen. Het grootste percentage elementen in slechte staat vinden we bij moestuinen, fruitbomen en bloemperken.

Uit het voorgaande blijkt dat hoge onderhoudskosten per $\mathrm{m}^{2}$, per $\mathrm{m}^{1}$ of per stuk niet betekenen dat de elementtypen in kwestie in een duidelijk slechtere onderhoudsstaat verkeren. Het is echter ook interessant om de relatie tussen onderhoudsstaat en onderhoudskosten te onderzoeken op objectniveau en daarbij ook de omvang van de objecten te betrekken. We verwachten namelijk dat een eigenaar keuzes gebaseerd op onderhoudskosten vooral zal maken op het niveau van een object als geheel. Immers, een elementtype kan per $\mathrm{m}^{2}$, per $\mathrm{m}^{1}$ of per stuk wel relatief duur zijn in onderhoud, maar het zal van object tot object verschillen hoe zwaar een elementtype meeweegt in de totale onderhoudskosten.

Uit Figuur 9a blijkt dat objecten die in een minder goede staat verkeren in het algemeen hogere berekende onderhoudskosten hebben. ${ }^{6}$ Figuur $9 \mathrm{~b}$ laat zien dat deze objecten meestal ook een grotere omvang (in hectares) hebben. ${ }^{7}$ De grootte van de objecten verklaart volgens verwachting hun totale berekende onderhoudskosten: grotere objecten zijn duurder in onderhoud (Figuur 9c). ${ }^{8}$

Daarnaast is het interessant om de relatie tussen onderhoudsstaat en berekende onderhoudskosten te leggen gecorrigeerd voor de omvang van een object. Dan wordt bijvoorbeeld duidelijk of een object dat in een minder goede staat is vooral bestaat uit dure elementtypen. Figuur 9d laat zien dat dit niet

6 De significantie van de trendlijn is getoetst met de Jonckheere-Terpstratest. Deze gaat na of er een trend is (positief of negatief) tussen een ordinale verklarende variabele (in dit geval onderhoudsstaat) en een continue responsvariabele (in dit geval onderhoudskosten). Getoetst wordt of de nulhypothese ('er is geen trend') verworpen moet worden. Is de kans dat de nul-hypothese klopt kleiner dan $5 \%$, dan wordt deze verworpen en is sprake van een significante trend. Deze kans wordt uitgedrukt door een $p$-waarde tussen 0 en 1 . Resultaat van de test: kosten bij onderhoudsfrequenties volgens Leidraad: $p=0,045$ (significant); kosten bij afwijkende onderhoudsfrequenties: $p=0,062$ (niet-significant).

7 Resultaat Jonckheere-Terpstratest: positieve relatie tussen onderhoudsstaat en omvang object: $p=0,006$ (significant).

8 De significantie van de trendlijn is getoetst via lineaire regressie. Resultaat van deze analyse is tevens een waarde $\mathrm{R}^{2}$. Deze parameter geeft aan hoe goed het regressiemodel (de gemodelleerde trendlijn) de puntenwolk verklaart. De $\mathrm{R}^{2}$ waarde ligt tussen 0 (geen relatie tussen trendlijn en puntenwolk) en 1 (puntenwolk valt geheel samen met de trendlijn). $\mathrm{Bij}$ onderhoudsfrequenties volgens Leidraad is $\mathrm{R}^{2}=0,793$ en $p=0,000$ (significant). Resultaat bij afwijkende onderhoudsfrequenties: $\mathrm{R}^{2}=0,692 ; p=0,000$ (significant). 
het geval lijkt te zijn: juist objecten die per eenheid oppervlakte relatief hoge onderhoudskosten vragen, verkeren in een goede onderhoudsstaat. ${ }^{9}$ Een verklaring is moeilijk te geven op grond van deze studie. De beweegredenen van eigenaren om veel of weinig te investeren in onderhoud van (dure) elementtypen zijn niet onderzocht. Bovendien gaat deze studie uit van berekende onderhoudskosten, niet van de door eigenaren werkelijk gemaakte onderhoudskosten.

\section{Prioriteit 1}

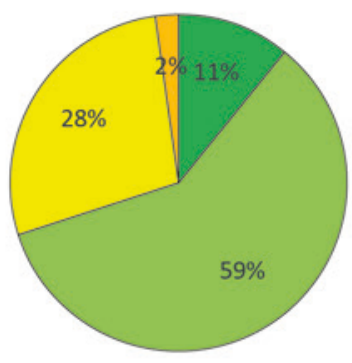

Bermen

$€ 0,31$ kosten $/ \mathrm{m}^{2} / \mathrm{jaar}$

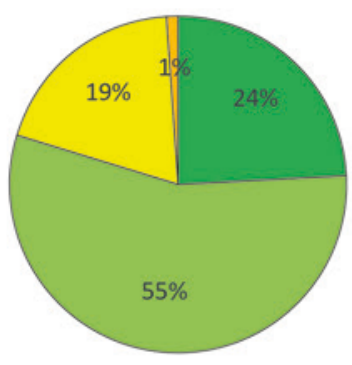

Gazons

$€ 0,41$ kosten $/ \mathrm{m}^{2} / \mathrm{jaar}$

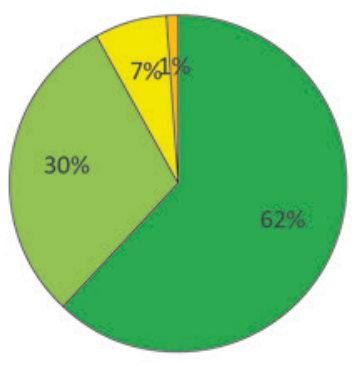

Paden en wegen (verhard)

$€ 1,05$ kosten $/ \mathrm{m}^{2} /$ jaar

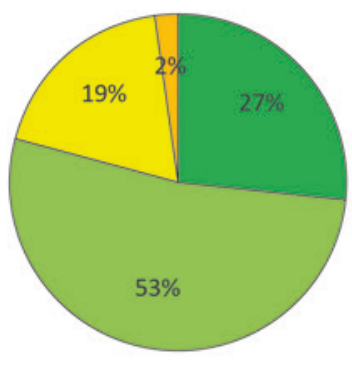

Parkbosrand

$€ 1,91$ kosten $/ \mathrm{m}^{1} / \mathrm{jaar}$

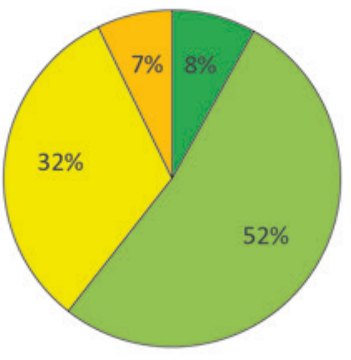

Ruigten in parkbos

$€ 0,33$ kosten $/ \mathrm{m}^{2} / \mathrm{jaar}$

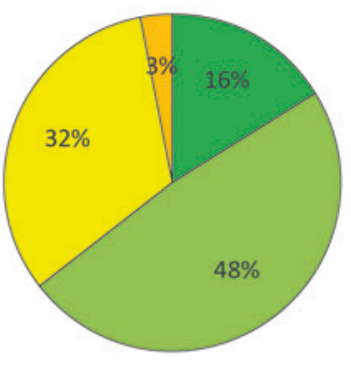

Waterpartijen en -lopen

$€ 0,47$ kosten $/ \mathrm{m}^{2} / \mathrm{jaar}$

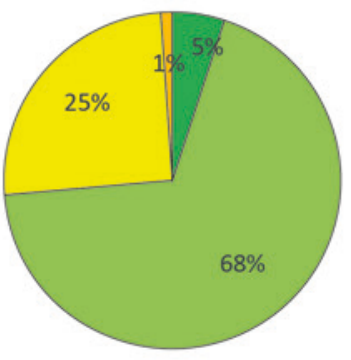

Gras langs waterlopen

$€ 1,15$ kosten $/ \mathrm{m}^{1} /$ jaar

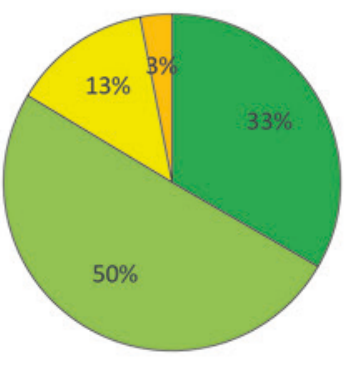

Berceaus

$€ 2,07$ kosten $/ \mathrm{m}^{2} / \mathrm{jaar}$

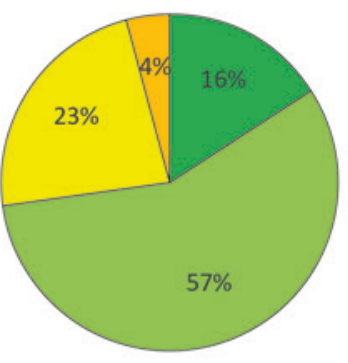

Parkweiden

$€ 0,39$ kosten $/ \mathrm{m}^{2} / \mathrm{jaar}$

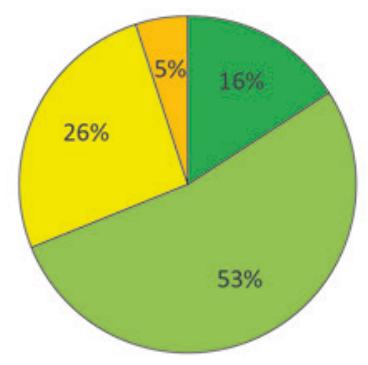

Paden (graspaden)

$€ 0,61$ kosten $/ \mathrm{m}^{2} /$ jaar

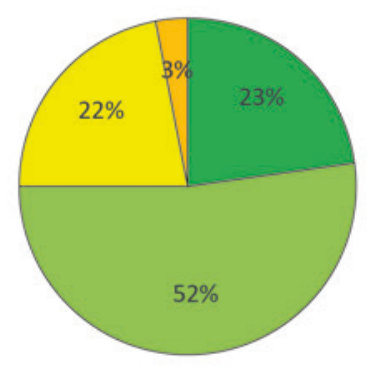

Paden en wegen (half-/onverhard)

$€ 1,54$ kosten $/ \mathrm{m}^{2} / \mathrm{jaar}$

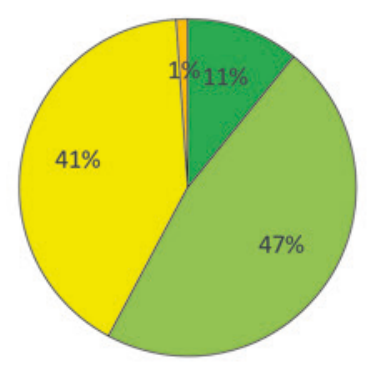

Boomsingels

$€ 2,56$ kosten/st/jaar

Figuur 8 Procentuele verdeling van de klassen onderhoudsstaat per elementtype in relatie tot de eenheidskosten voor onderhoud. Legenda en vervolg van deze figuur op volgende bladzijden.

\footnotetext{
9 Resultaat Jonckheere-Terpstratest: kosten per ha bij onderhoudsfrequenties volgens Leidraad: $p=0,000$ (significant); kosten per ha bij afwijkende onderhoudsfrequenties: $p=0,000$ (significant).
} 


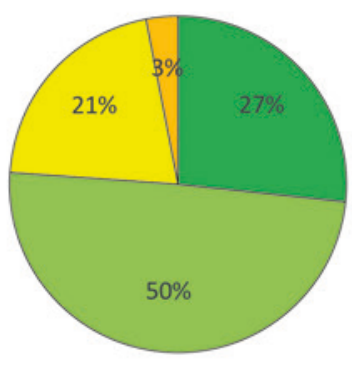

Heestergroepen

$€ 2,65$ kosten $/ \mathrm{m}^{2} / \mathrm{jaar}$

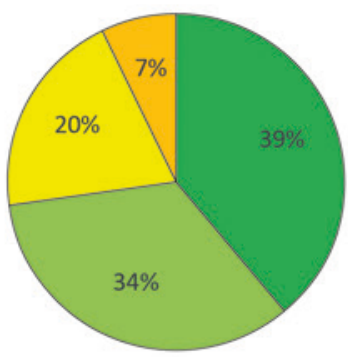

Hagen ( $2 x$ snoeien)

$€ 5,59$ kosten $/ \mathrm{m}^{1} / \mathrm{jaar}$

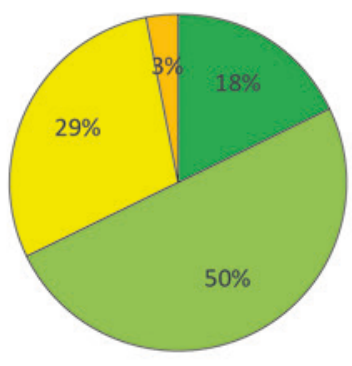

Laanbomen

$€ 23,01$ kosten/st/jaar

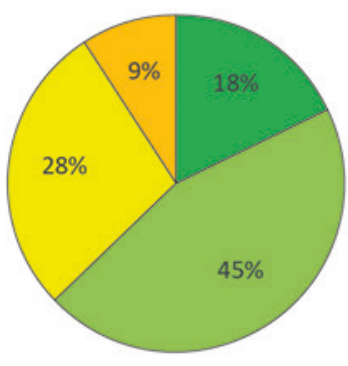

Fruitbomen

$€ 55,92$ kosten/st/jaar

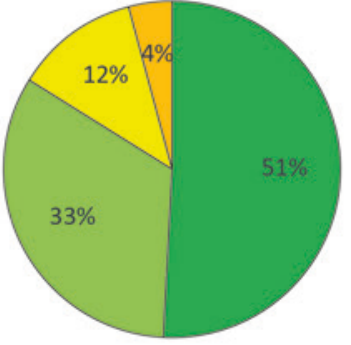

Zichtassen en zichtlijnen

$€ 5,01$ kosten $/ \mathrm{m}^{1} / \mathrm{jaar}$

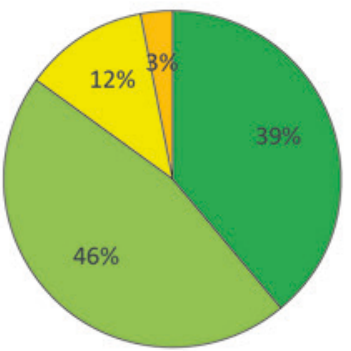

Hagen ( $1 x$ snoeien)

$€ 5,60$ kosten $/ \mathrm{m}^{1} / \mathrm{jaar}$

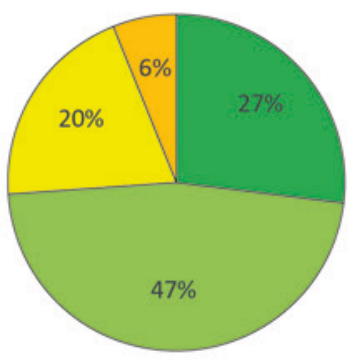

Solitaire bomen en boomgroepen

$€ 25,23$ kosten/st/jaar

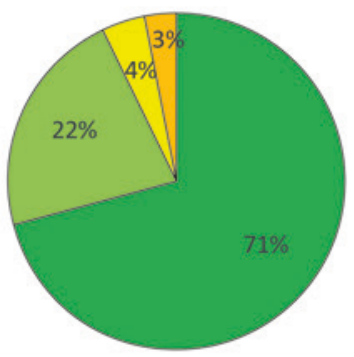

Eenvoudige houten loopbruggetjes $€ 71,32$ kosten/st/jaar

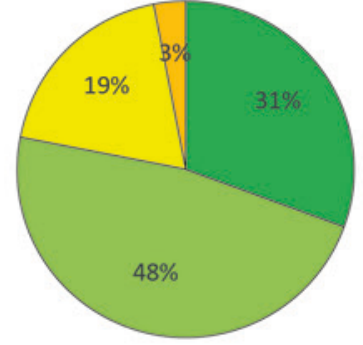

Heesterborders

$€ 5,44$ kosten $/ \mathrm{m}^{2} / \mathrm{jaar}$

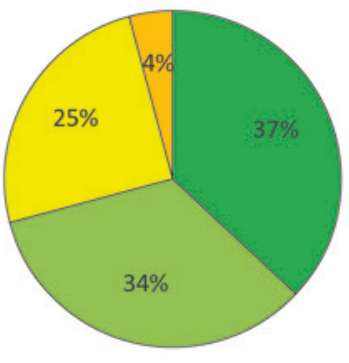

Beschoeiing

$€ 6,42$ kosten $/ \mathrm{m}^{1} / \mathrm{jaar}$

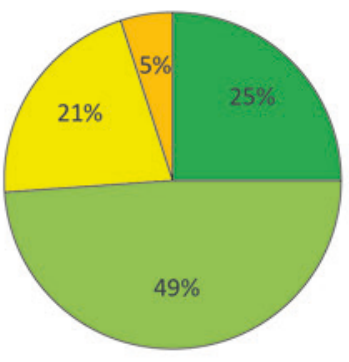

Topiaria

$€ 27,72$ kosten/st/jaar

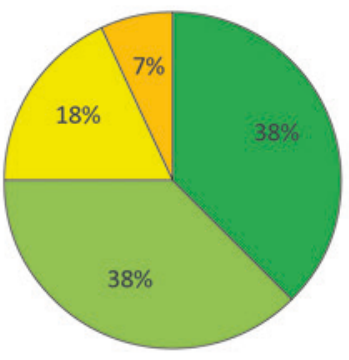

Leifruit

$€ 107,91$ kosten/st/jaar

Figuur 8 (vervolg) 
Prioriteit 2

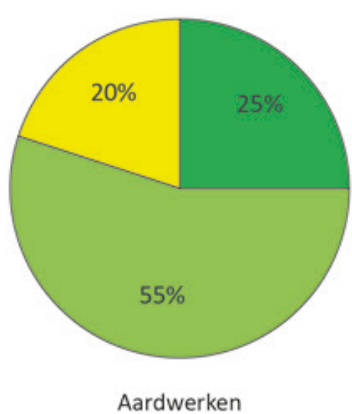

$€ 0,37$ kosten $/ \mathrm{m}^{2} / \mathrm{jaar}$

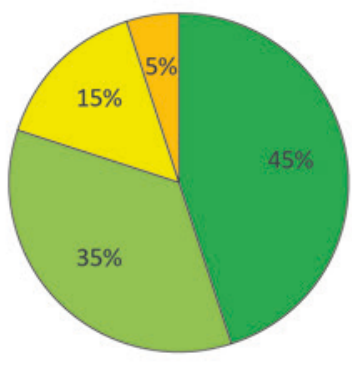

Vaste plantenborders

$€ 19,19$ kosten $/ \mathrm{m}^{2} / \mathrm{jaar}$

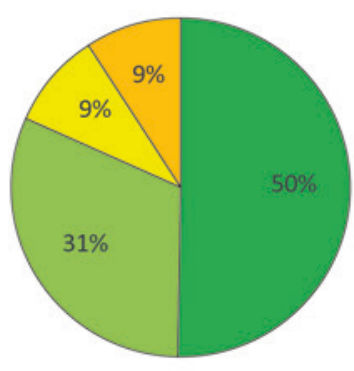

Bloemperken

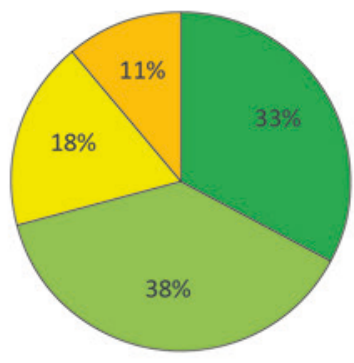

Moestuin

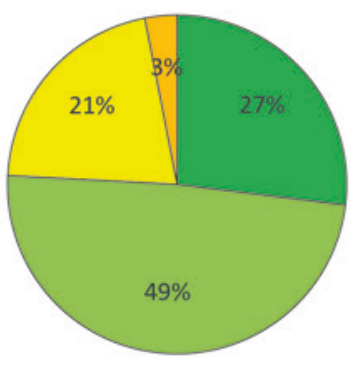

Klimplanten

$€ 3,23$ kosten $/ \mathrm{m}^{2} /$ jaar

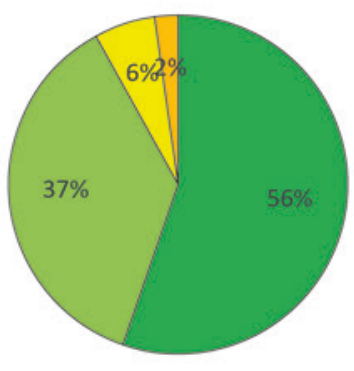

Leibomen en knotbomen $€ 26,03$ kosten/st/jaar

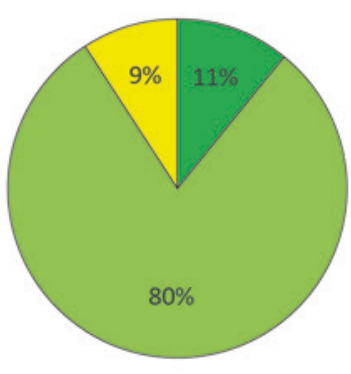

Hakhout

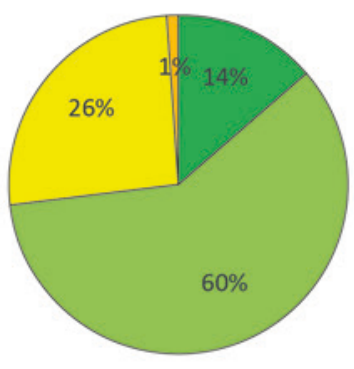

Parkbos

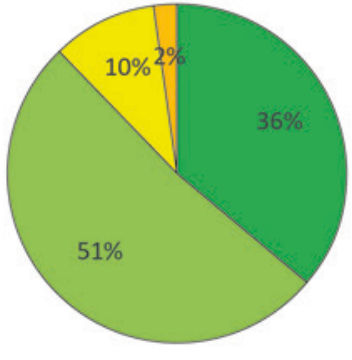

Rozenperken

$€ 19,12$ kosten $/ \mathrm{m}^{2} /$ jaar

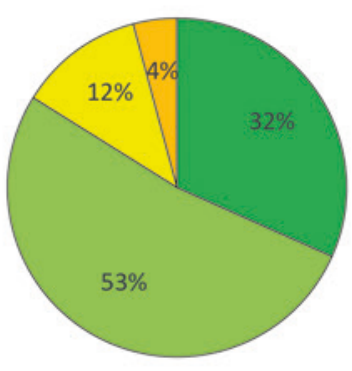

Kuipplanten

$€ 114,66$ kosten/st/jaar

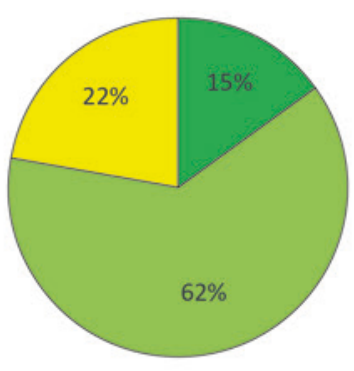

Houtwal en houtsingels

onderhoudsstaat goed

onderhoudsstaat redelijk

onderhoudsstaat matig

onderhoudsstaat slecht

Figur 8 (vervolg) 

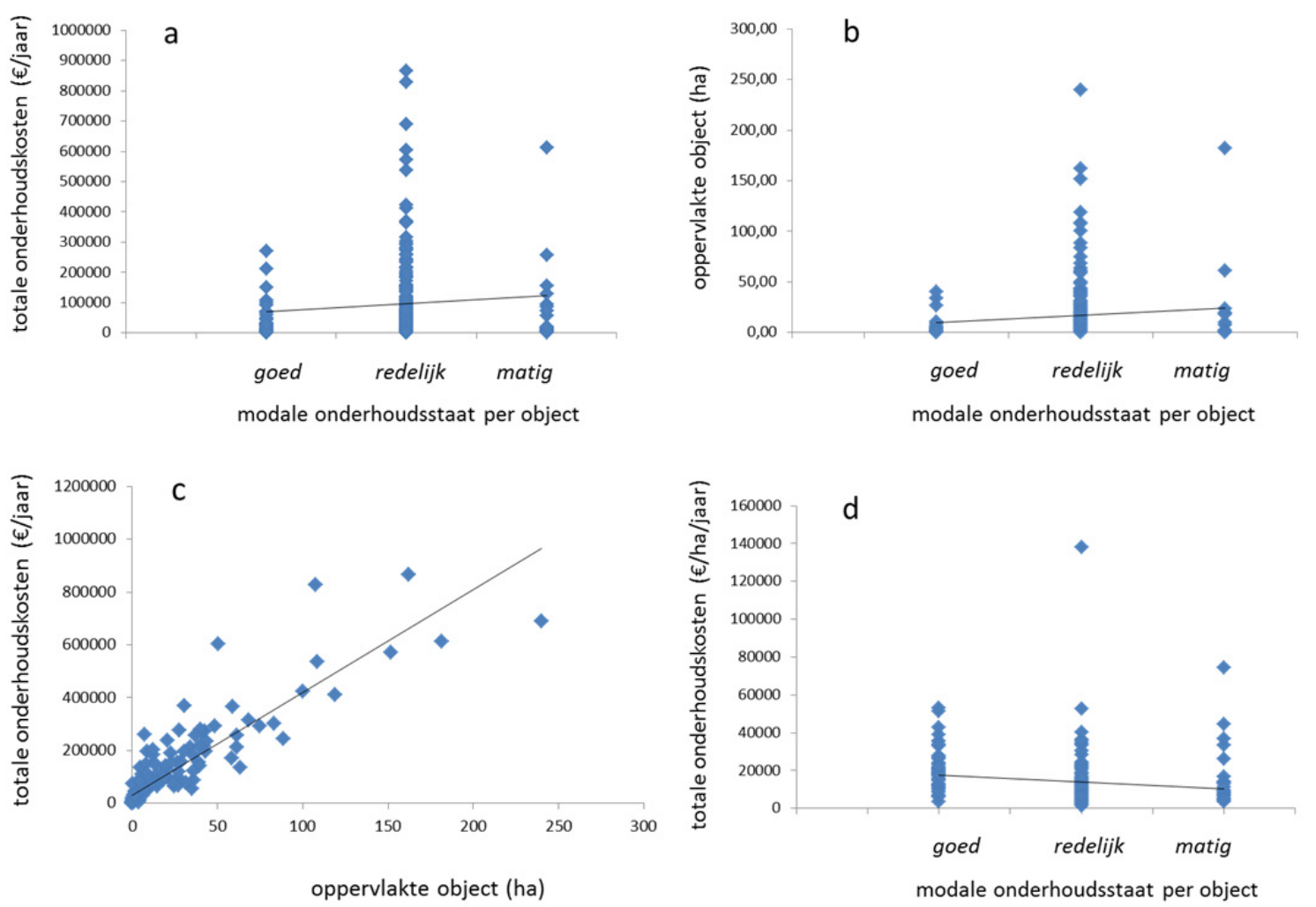

Figuur 9 Positieve trend tussen de modale onderhoudsstaat per object en de totale onderhoudskosten voor het betreffende object. De puntenclusters in de grafiek vertegenwoordigen de 209 objecten uit de steekproef. Onderhoudskosten uitgaande van sober en doelmatig onderhoud volgens de Leidraad subsidiabele instandhoudingskosten 2013.

\subsubsection{Schatting onderhoudskosten elementtypen niet in RCE- standaardbegrotingsmodel}

In dit onderzoek aan een steekproef van 209 objecten is een zevental groene elementtypen wel geïnventariseerd, maar niet in de gestandaardiseerde kostenberekening meegenomen. Dit zijn elementtypen die deels wel in de Sim worden genoemd, maar niet in de Leidraad als subsidiabel zijn aangemerkt. De betreffende elementtypen zijn dan ook niet opgenomen in het RCEstandaardbegrotingsmodel groen (d.d. 8-9-2015). Tabel 21 laat zien om welke elementtypen het gaat.

Met uitzondering van parkbos en de stinzenplanten waren deze elementtypen qua omvang van gering belang in de steekproef als geheel ( $1 \%$ of minder van de totale oppervlakte of lengte van alle elementen in de steekproef). Omdat de inventarisatie in de zomer heeft plaatsgevonden, konden de stinzenplanten niet worden opgenomen. Toch is duidelijk dat er sprake is van onderschatting van de werkelijke onderhoudskosten doordat de genoemde elementtypen niet in deze studie zijn meegenomen. Parkbos is qua omvang een belangrijk elementtype en een aantal van de andere elementtypen vergt relatief veel onderhoudsinspanning. Daarom is op basis van SNL (2016) en deskundigenoordeel een aanvullende schatting gemaakt van de jaargemiddelde onderhoudskosten van deze elementtypen. De aannamen die hierbij zijn gehanteerd, staan in Bijlage 6. 
Tabel 21 Aanvullend geschatte onderhoudskosten per eenheid oppervlakte voor elementtypen die niet zijn meegenomen in de gestandaardiseerde kostenberekening.

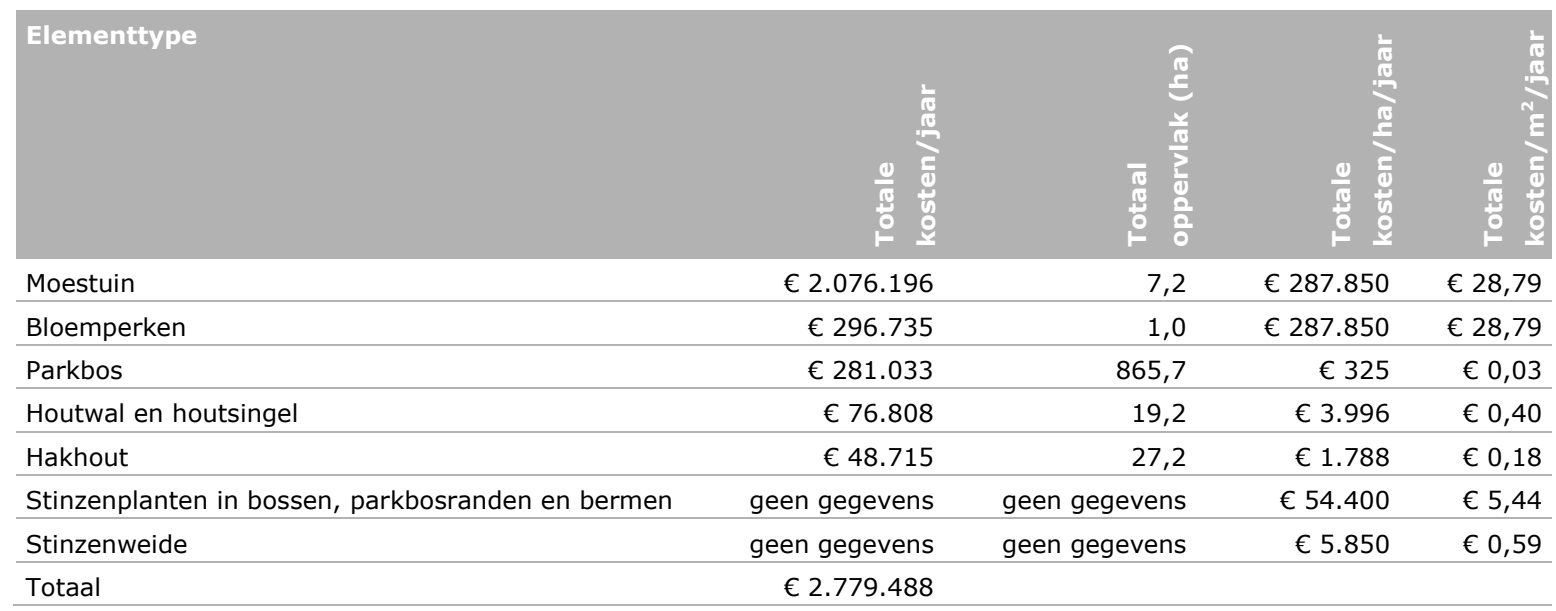

Uit Tabel 21 blijkt dat de aanvullend geschatte onderhoudskosten 14\% van de totaal geschatte kosten op steekproefniveau bedragen. Het grootste deel daarvan (10\% van de totaal geschatte kosten op steekproefniveau) komt voor rekening van moestuinen, die relatief intensief onderhoud vragen.

\subsection{Extrapolatie van steekproef naar heel Nederland}

De gegevens uit de steekproef vormen de basis voor het berekenen van de totale onderhoudskosten voor alle groene rijksmonumenten in Nederland. Dit is gedaan volgens de methode die staat beschreven in paragraaf 3.6. Tabel 22 laat het resultaat zien uitgaande van sober en doelmatig onderhoud volgens de Leidraad en Tabel 23 toont de bedragen wanneer we uitgaan van afwijkende frequenties voor sober en doelmatig onderhoud.

Tabel 22 Geschatte totale onderhoudskosten voor het rijksbeschermde groene erfgoed in Nederland bij sober en doelmatig onderhoud.*

\begin{tabular}{lrr} 
& Totale kosten & Standaardafwijking \\
Kosten elementen prioriteit 1 & $€ 122.437 .973$ & $€ 10.349 .559$ \\
\hline Kosten elementen prioriteit 2 & $€ 9.347 .427$ & $€ 1.367 .332$ \\
\hline Kosten totaal & $€ 131.785 .400$ & $€ 10.654 .048$ \\
\hline
\end{tabular}

* Volgens de Leidraad subsidiabele instandhoudingskosten 2013. De schatting is gebaseerd op de onderhoudskosten per object uit de steekproef.

Tabel 23 Geschatte totale onderhoudskosten voor het rijksbeschermde groene erfgoed in Nederland bij afwijkende frequenties voor sober en doelmatig onderhoud.*

\begin{tabular}{lrrr} 
& Totale kosten & Standaardafwijking \\
Kosten elementen prioriteit 1 & $€ 175.487 .678$ & $€ 15.976 .252$ \\
\hline Kosten elementen prioriteit 2 & $€ 9.865 .636$ & $€ 1.402 .170$ \\
\hline Kosten totaal & $€ 185.353 .314$ & $€ 16.255 .277$ \\
\hline
\end{tabular}

* De schatting is gebaseerd op de onderhoudskosten per object uit de steekproef.

Het aandeel van elementtypen met prioriteit 2 in de totale kosten is beperkt: 7\% uitgaande van sober en doelmatig onderhoud volgens de Leidraad (Tabel 22) en $5 \%$ uitgaande van afwijkende frequenties voor sober en doelmatig onderhoud (Tabel 23). 
Een totaalbedrag van $€ 132$ miljoen voor de geschatte totale kosten bij sober en doelmatig onderhoud volgens de Leidraad komt neer op een gemiddelde van ongeveer $€ 95.000$ per object. Het gemiddelde oppervlak per object in de steekproef is 16,7 ha. Als we dit gemiddelde oppervlak van 16,7 ha ook aannemen voor alle circa 1.400 monumenten met een rijksbeschermde groenaanleg, dan komen de kosten per ha bij sober en doelmatig onderhoud uit op gemiddeld $€ 5.689$ per ha. Hierbij wordt aangetekend dat dit slechts een gemiddelde is. In de praktijk worden de onderhoudskosten per ha vooral bepaald door de aanwezige elementtypen en door de daadwerkelijk gehanteerde onderhoudsfrequentie. Om hun groene erfgoed in een goede toestand te houden, kunnen eigenaren hogere onderhoudsfrequenties toepassen dan voorgeschreven volgens de Leidraad.

Tabel 24 laat de geschatte totale onderhoudskosten per categorie groen erfgoed zien uitgaande van sober en doelmatig onderhoud volgens de Leidraad. Tabel 25 toont de bedragen wanneer we uitgaan van afwijkende frequenties voor sober en doelmatig onderhoud.

In Figuur 10 is de relatieve verdeling over de vier landsdelen weergegeven van de geëxtrapoleerde onderhoudskosten voor rijksbeschermd groen erfgoed. Bij de extrapolatie is uitgegaan van onderhoudsfrequenties volgens de Leidraad. De percentages zijn ongeveer dezelfde wanneer we uitgaan van afwijkende frequenties voor sober en doelmatig onderhoud.

Tabel 24 Geschatte totale onderhoudskosten, per categorie groen erfgoed, voor het rijksbeschermde groene erfgoed in Nederland.*

\begin{tabular}{lcr} 
Categorie groen erfgoed & Totale kosten/jaar & Standaardafwijking \\
Groenaanleg bij buitenplaatsen \& landgoederen & $€ 103.314 .173$ & $€ 9.791 .373$ \\
\hline Stadsparken en plantsoenen & $€ 10.118 .789$ & $€ 3.517 .807$ \\
\hline Begraafplaatsen & $€ 2.386 .498$ & $€ 1.806 .361$ \\
\hline Groenaanleg bij religieuze gebouwen & $€ 1.922 .622$ & $€ 630.671$ \\
\hline Diversen & $€ 1.794 .896$ \\
\hline Villatuinen & $€ 1.193 .940$ \\
\hline Tuinen bij bedrijven, overheid en organisaties & $€ 1.179 .929$ \\
\hline Groenaanleg bij medische en sociale instellingen & $€ 1.094 .793$ \\
\hline Tuinen en parken bij landhuizen & $€ 850.596$ & $€ 528.674$ \\
\hline Boerentuinen en boerenerven & $€ 259.785$ \\
\hline Erven & $€ 808.589$ & $€ 422.292$ \\
\hline Collectietuinen & $€ 409.590$ \\
\hline Pastorietuinen & $€ 316.869$ \\
\hline Stadstuinen & $€ 238.611$ \\
\hline Eindtotaal & $€ 351.028$ \\
\hline
\end{tabular}

* Bij sober en doelmatig onderhoud volgens de Leidraad subsidiabele instandhoudingskosten 2013. De schatting is gebaseerd op de onderhoudskosten per object uit de steekproef. 
Tabel 25 Geschatte totale onderhoudskosten, per categorie groen erfgoed, voor het rijksbeschermde groene erfgoed in Nederland bij afwijkende frequenties voor sober en doelmatig onderhoud.

\begin{tabular}{|c|c|c|}
\hline & Totale kosten/jaar & Standaardafwijking \\
\hline Groenaanleg bij buitenplaatsen \& landgoederen & $€ 140.520 .595$ & $€ 14.665 .116$ \\
\hline Stadsparken en plantsoenen & $€ 16.664 .153$ & $€ 5.992 .912$ \\
\hline Groenaanleg bij religieuze gebouwen & $€ 3.932 .599$ & $€ 1.235 .566$ \\
\hline Villatuinen & $€ 2.768 .264$ & $€ 602.782$ \\
\hline Tuinen bij bedrijven, overheid en organisaties & $€ 2.249 .039$ & $€ 1.120 .415$ \\
\hline Groenaanleg bij medische en sociale instellingen & $€ 1.718 .345$ & $€ 378.232$ \\
\hline Tuinen en parken bij landhuizen & $€ 1.669 .633$ & $€ 637.511$ \\
\hline Boerentuinen en boerenerven & $€ 1.287 .448$ & $€ 205.219$ \\
\hline Stadstuinen & $€ 376.454$ & $€ 87.043$ \\
\hline Eindtotaal & $€ 185.353 .314$ & \\
\hline
\end{tabular}

* De schatting is gebaseerd op de onderhoudskosten per object uit de steekproef.

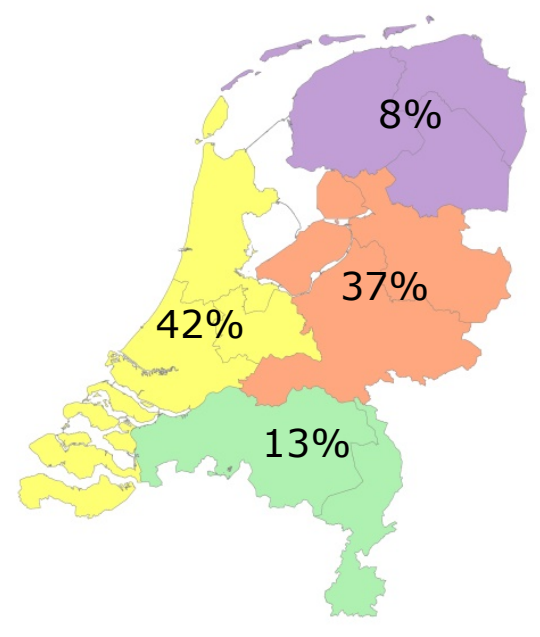

Figuur 10 Verdeling van de geëxtrapoleerde onderhoudskosten voor rijksbeschermd groen erfgoed over de vier landsdelen. Bij de extrapolatie is uitgegaan van onderhoudsfrequenties volgens de Leidraad subsidiabele instandhoudingskosten 2013. 


\section{$6 \quad$ Overige bevindingen en reflectie}

\subsection{Afwijkingen van de omschrijvingen van de rijksmonumenten}

Bij 44\% van de objecten in de steekproef wijkt de aangetroffen situatie af van de omschrijving. Tabel 26 laat zien welke typen afwijkingen we onderscheiden en hoe vaak deze voorkomen. Gedetailleerdere overzichten van de waargenomen afwijkingen zijn opgenomen in Bijlage 7. Bij veel objecten komen naast elkaar meerdere typen afwijkingen van de omschrijving voor.

Gemiddeld over alle categorieën groen erfgoed zijn in 30\% van de gevallen een of meerdere elementen die zijn genoemd in de omschrijving verdwenen (Tabel 26). Elementen die in de omschrijving worden genoemd, zijn vaak van monumentale waarde. Bijlage 7 laat zien dat de meeste objecten met verdwenen elementen voorkomen in de categorieën collectietuinen, pastorietuinen, tuinen bij bedrijven en organisaties en bij landhuizen (in 50\% van de objecten elementen verdwenen). Ook in de categorie boerentuinen en -erven zijn relatief vaak (45\% van de objecten) een of meerdere elementen genoemd in de omschrijving verdwenen. De meeste objecten met verdwenen elementen liggen in Zuid-Holland (in $50 \%$ van de objecten elementen verdwenen), Limburg (47\%), Drenthe en Friesland (38\%).

Het komt ook voor dat in het veld een rijkere groenaanleg is aangetroffen dan omschreven in de omschrijving van het monument. De omschrijvingen zijn vaak enkele decennia geleden opgesteld en verschillen van object tot object in omvang en detaillering. Sommige omschrijvingen zijn uitermate summier, andere vrij uitgebreid met veel aandacht voor individuele elementen in de groenaanleg. Door deze verschillen is het mogelijk dat er elementen zijn verdwenen zonder dat dit op basis van de omschrijving duidelijk wordt. Aanbevolen wordt het kennisdeel van de omschrijvingen van rijksmonumenten op orde te brengen.

Tabel 26 Waargenomen afwijkingen van de omschrijving.

\begin{tabular}{lrr} 
Waargenomen afwijking van omschrijving & Aantal objecten & 161 \\
Ontbrekende beschrijving aanlegstijl & 63 & $77 \%$ \\
\hline Groenelementen aangetast of verdwenen & $30 \%$ \\
\hline Tuin(onderdelen) niet beschreven (onduidelijk wat beschermd is) & 25 & $19 \%$ \\
\hline Afwijkende aanlegstijl & $6 \%$ \\
\hline Afwijkende kadastrale percelen & $3 \%$ \\
\hline Twijfelachtige monumentale waarde & $5 \%$
\end{tabular}

\subsection{Veldimpressie onderhoudsstaat objecten}

\subsubsection{Vergelijking twee methoden onderhoudsstaat op objectniveau}

In hoofdstuk 4 staat de onderhoudsstaat van de geïnventariseerde objecten centraal. Alle resultaten die in hoofdstuk 4 zijn gepresenteerd, hebben als basis de score voor de onderhoudsstaat van individuele groenelementen. Tijdens de veldinventarisatie is echter niet alleen de onderhoudsstaat van elk aangetroffen groenelement opgenomen. Bij de bezochte objecten is tevens de onderhoudsstaat van het object als geheel geschat. Dit is door de veldonderzoeker steeds na afloop van het veldwerk gedaan.

Figuur 11 laat zien hoe de scores over de vier klassen van onderhoudsstaat zijn verdeeld. In het linker diagram is de verdeling weergegeven voor de modale onderhoudsstaat per object. De achterliggende 
gegevens bij dit diagram zijn de, per object berekende, modale (meest voorkomende) waarden voor de onderhoudsstaat. Deze modale waarden zijn berekend over de scores van alle afzonderlijke elementen in het object. In het rechter diagram is de verdeling weergegeven van de onderhoudsstaat die direct op objectniveau is geschat door de onderzoeker na afloop van het veldbezoek.

Wat opvalt, is dat de verdeling van de scores over de vier klassen van onderhoudsstaat gelijkmatiger is bij de veldschatting dan bij de uit de elementscores berekende modale waarde. Bij de veldschatting valt $6 \%$ van de objecten in de klasse slecht, terwijl deze klasse ontbreekt bij de berekende modale waarde. Hoewel 3\% van de elementen in de steekproef de score slecht heeft gekregen (zie Figuur 5 op bladzijde 32), leidt dit voor geen enkel object tot een modale score slecht.

Hoe kunnen we de verschillen tussen de resultaten van beide methoden verklaren? Mogelijk wordt de score van de in het veld geschatte onderhoudsstaat vooral bepaald door de staat van de groene elementen in een object, terwijl bij de modale staat de blauwe en overige relevante elementen even zwaar worden meegewogen als de groene.

Welke methode is de beste? De veldschatting (een visuele schatting) heeft het voordeel dat deze snel, direct en integraal is. Er wordt meteen een oordeel op objectniveau gegeven. Weliswaar moet de waarnemer daarvoor het object doorkruisen, maar dit kan veel sneller dan wanneer de waarnemer onderweg de onderhoudsstaat van elk afzonderlijk groenelement moet schatten. Daartegenover staat een aantal voordelen van het berekenen van de modale staat uit de scores van individuele elementen. Bij deze methode bestaat niet het risico dat de onderhoudsstaat van bepaalde elementtypen onbewust zwaarder of minder zwaar wordt meegewogen in het oordeel. Ook past deze methode beter bij het doel van een gestandaardiseerde, objectieve en herhaalbare aanpak. Immers, doordat objecten tussen en binnen categorieën groen erfgoed sterk verschillen in de samenstelling en onderlinge positie van elementen, is het lastig om direct op objectniveau te werken met een beeldkwaliteitsdocument. Dit kan veel gemakkelijker op elementtypeniveau (vgl. Debie \& Verkuijl 2016). Het risico van significante waarnemerseffecten bestaat bij beide methoden, maar gegeven het voorgaande is afstemming tussen waarnemers om te komen tot vergelijkbare schattingen gemakkelijker met de methode waarbij de modale onderhoudsstaat wordt berekend uit de scores voor de afzonderlijke elementen. Deze methode is ons inziens daarom de beste van de twee.

\section{Onderhoudsstaat modaal}

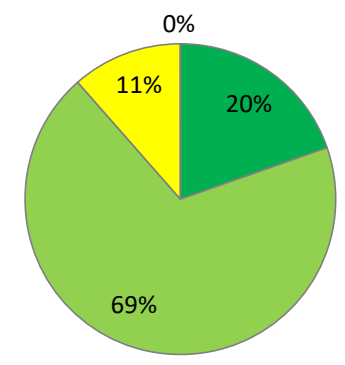

\section{Onderhoudsstaat in veld geschat}
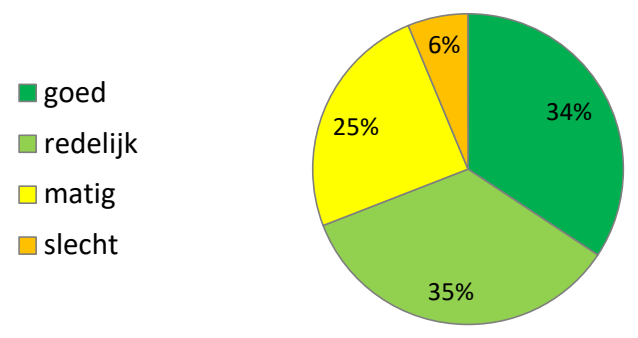

Figuur 11 Verdeling scores onderhoudsstaat op objectniveau. Links de modale staat berekend uit de scores van de aanwezige elementen (gebaseerd op gegevens voor 209 objecten). Rechts de in het veld direct op objectniveau geschatte staat (gebaseerd op gegevens voor 207 objecten).

\subsubsection{Foto-impressie contrasten onderhoudsstaat}

In deze paragraaf geven we een indruk van de variatie in de aangetroffen onderhoudsstaat aan de hand van foto's gemaakt tijdens de veldinventarisatie. In de meeste gevallen gaat het om contrasten op het niveau van groenelementen binnen objecten. Soms geven de foto's een beeld van verschillen in onderhoudsstaat op objectniveau. Uit de fotoreeks in deze paragraaf kunnen geen kwantitatieve conclusies worden getrokken. Voor dergelijke conclusies wordt verwezen naar hoofdstuk 4. 

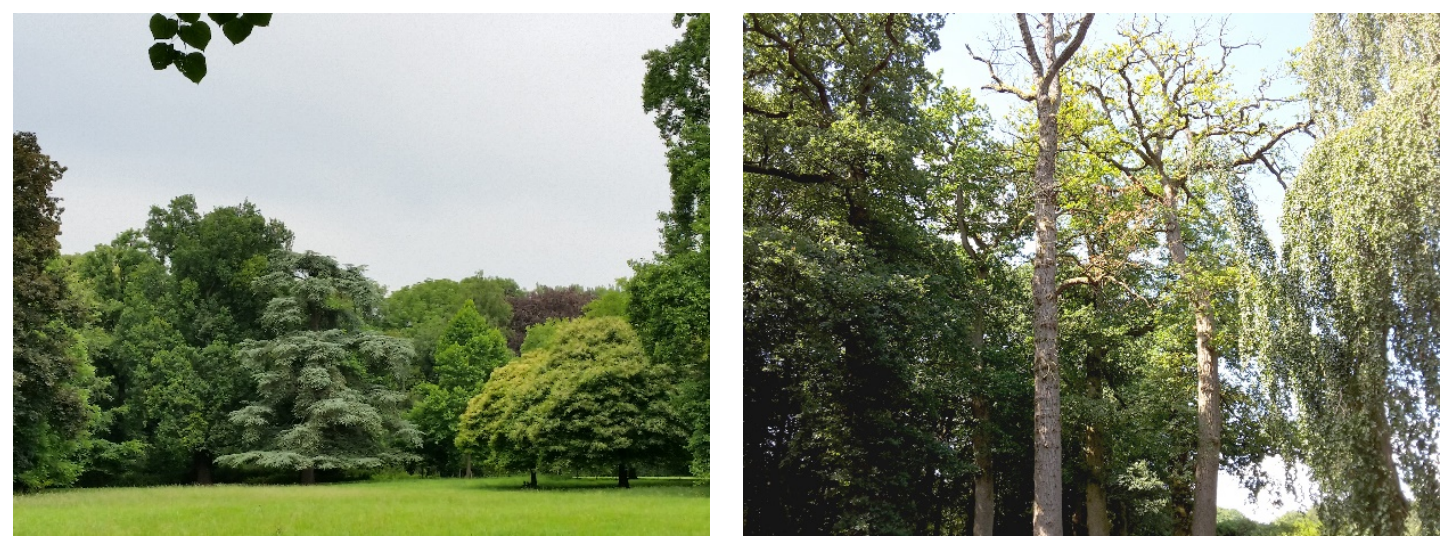

Figuur 12 Links een parkbosrand in goede staat met een gevarieerd en gezond bomenbestand en rechts een park waarin dode bomen zijn gehandhaafd.
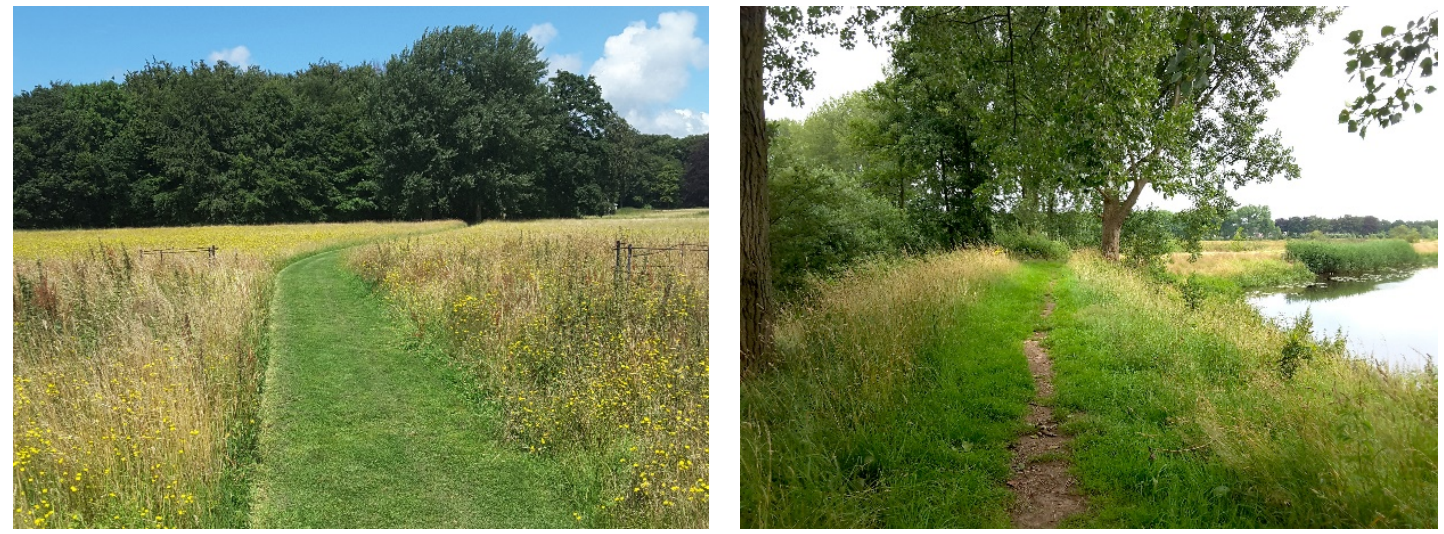

Figuur 13 Links een graspad in goede staat en rechts een uitgesleten graspad in slechte staat.
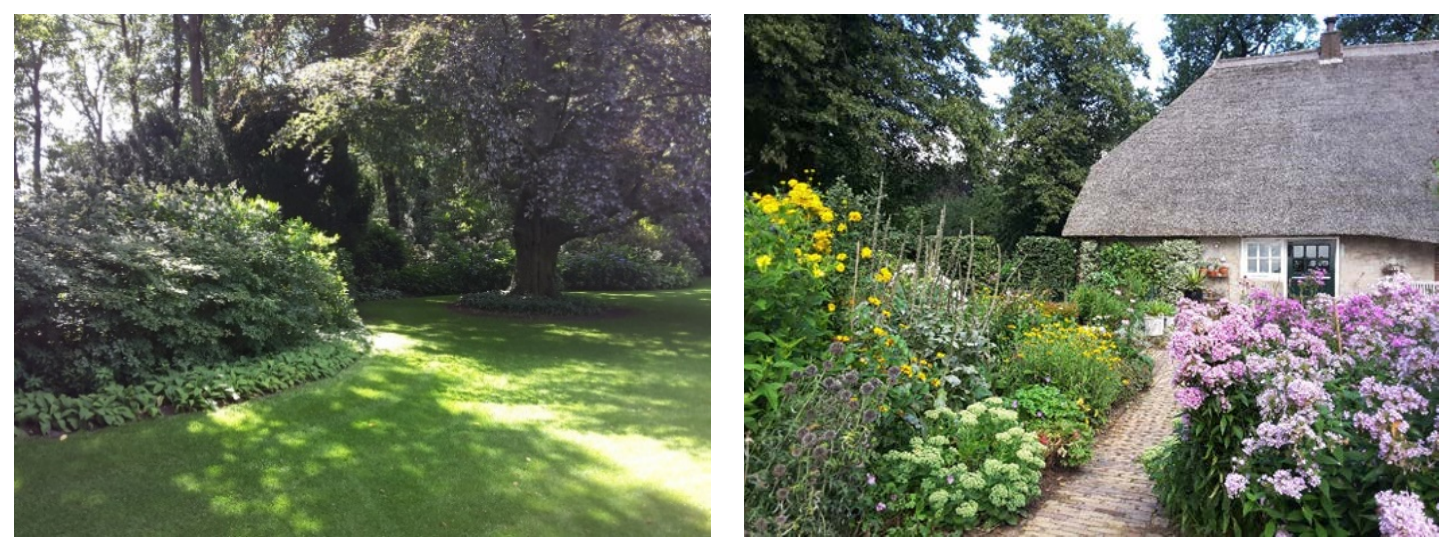

Figuur 14 Beide foto's tonen in goede staat verkerende beplanting. Links een robuuste en rechts een kleinschalige gedetailleerde beplanting. 

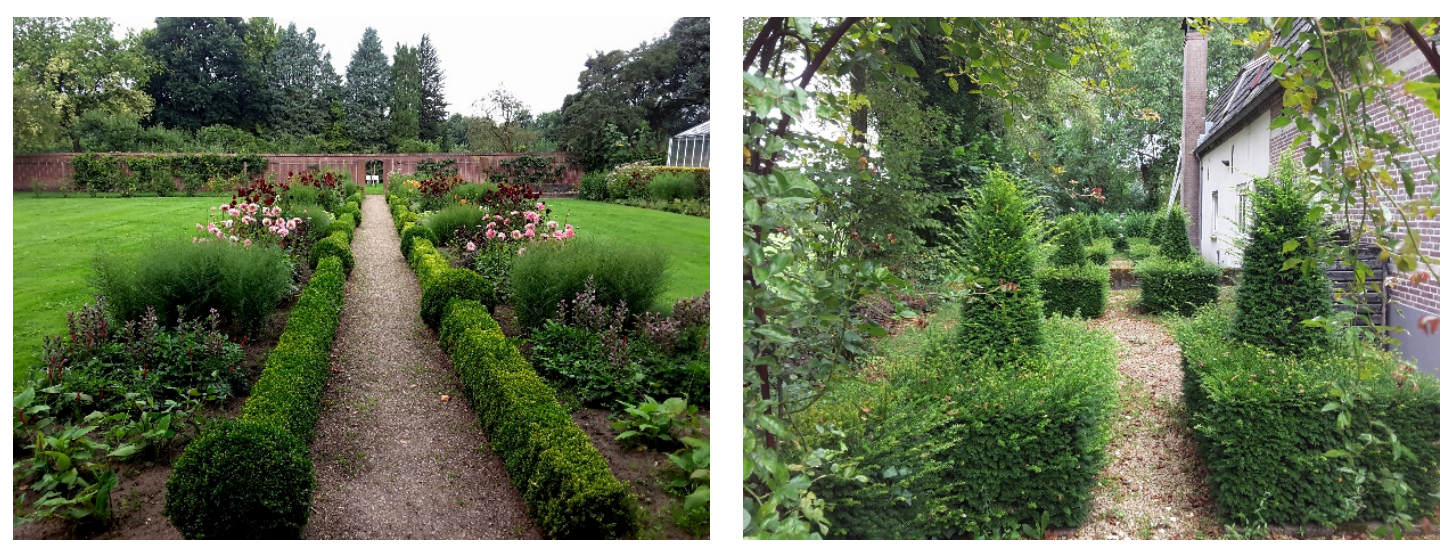

Figuur 15 Links hagen in een goede tot redelijke onderhoudsstaat en rechts hagen in een matige staat.
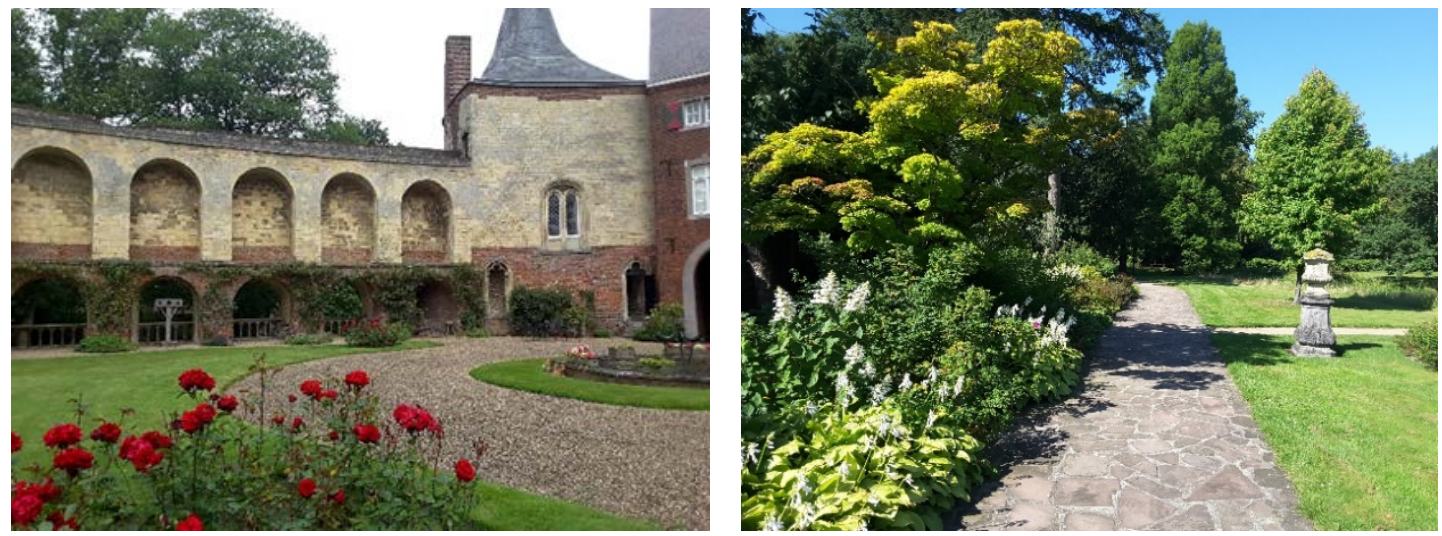

Figuur 16 Twee buitenplaatsen waarvan de groenaanleg in goede staat verkeert.
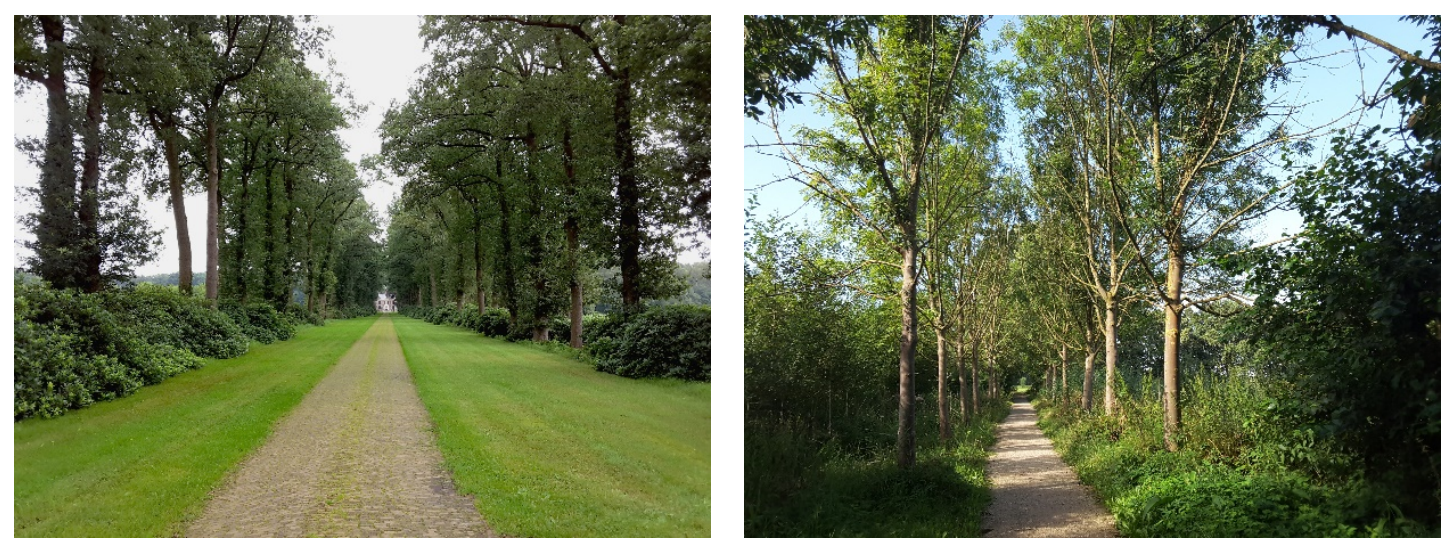

Figuur 17 Links een goede en rechts een slechte onderhoudsstaat bij zichtassen, lanen en bermen. 

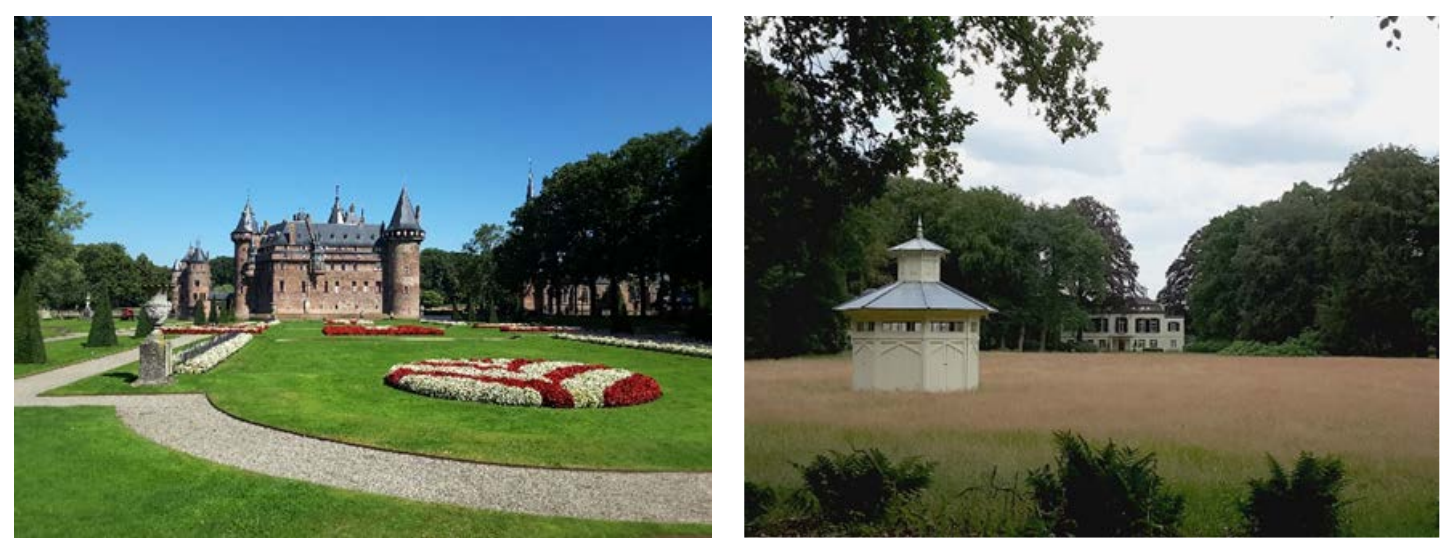

Figuur 18 Twee voorbeelden van goed onderhouden buitenplaatsen.
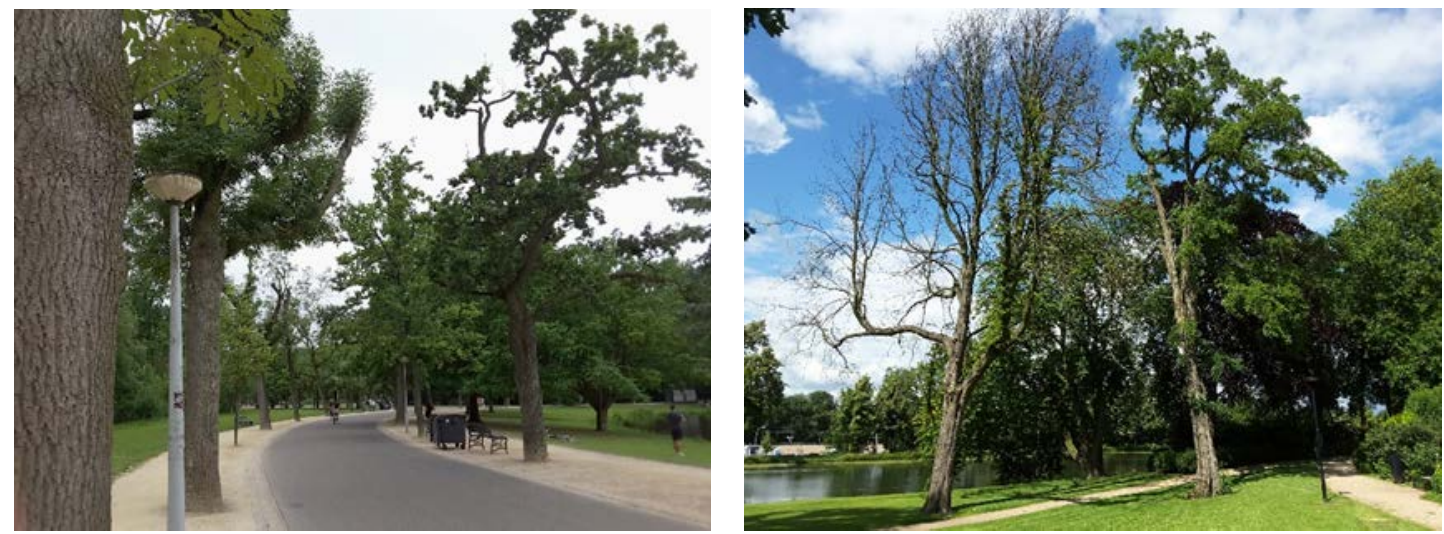

Figuur 19 Monumentaal bomenbestand in openbare parken. Links laanbomen in een matige staat en rechts een parkboom in een slechte onderhoudsstaat.
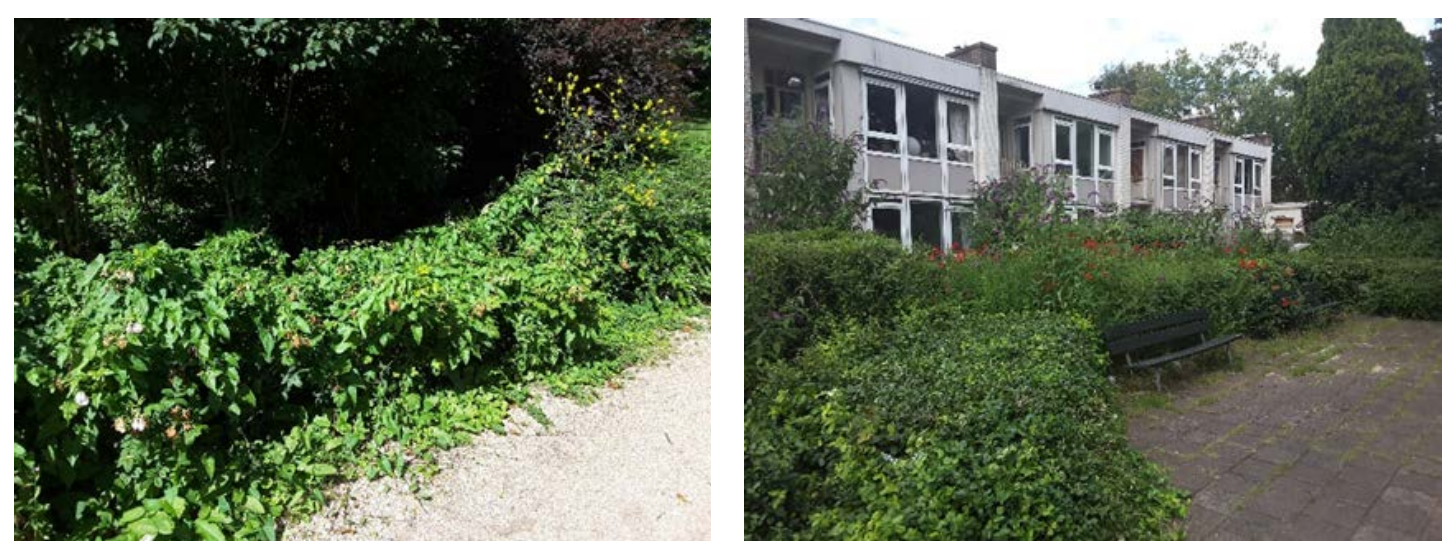

Figuur 20 Plantvakken bij gemeentelijke objecten die in een slechte tot matige staat verkeren. 

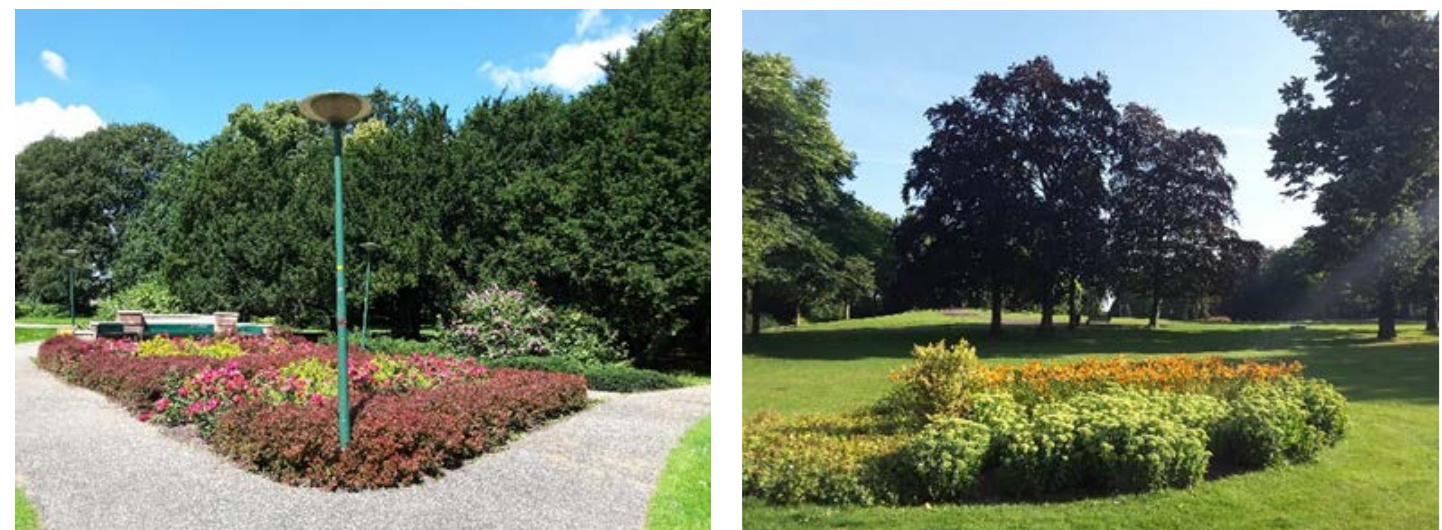

Figuur 21 Plantvakken bij gemeentelijke parken die in goede onderhoudsstaat verkeren, met een gevarieerd historisch sortiment afgestemd op de aanlegstijl.
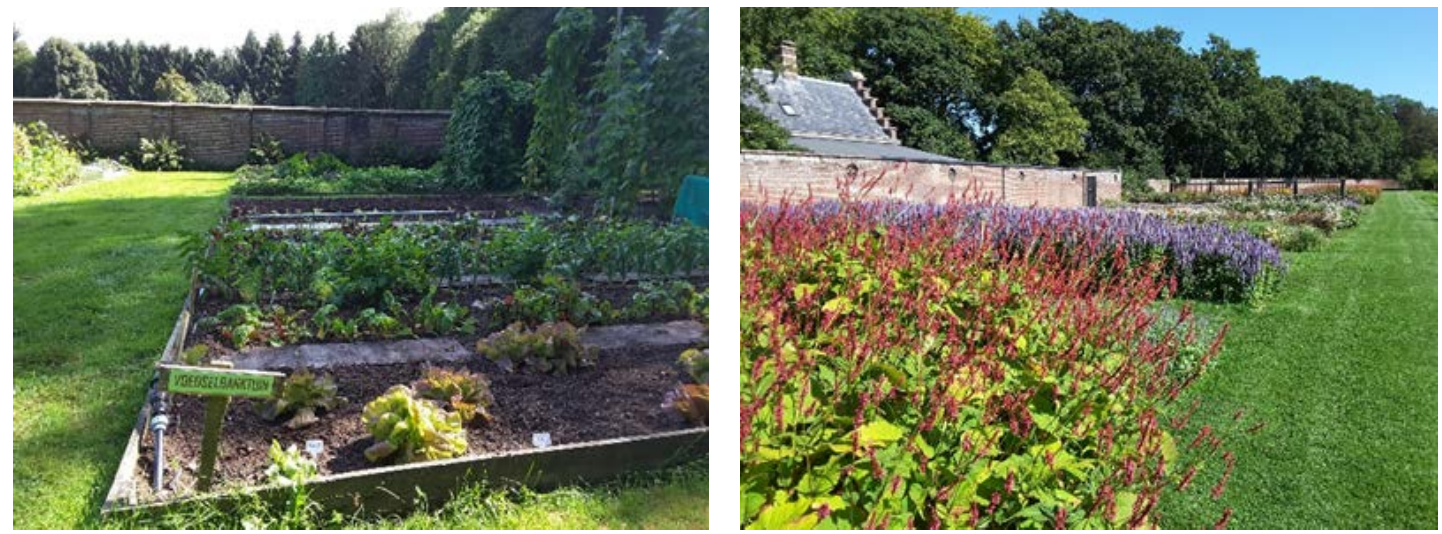

Figuur 22 Links een moestuin in goede onderhoudsstaat en rechts een tot bloementuin omgevormde moestuin.
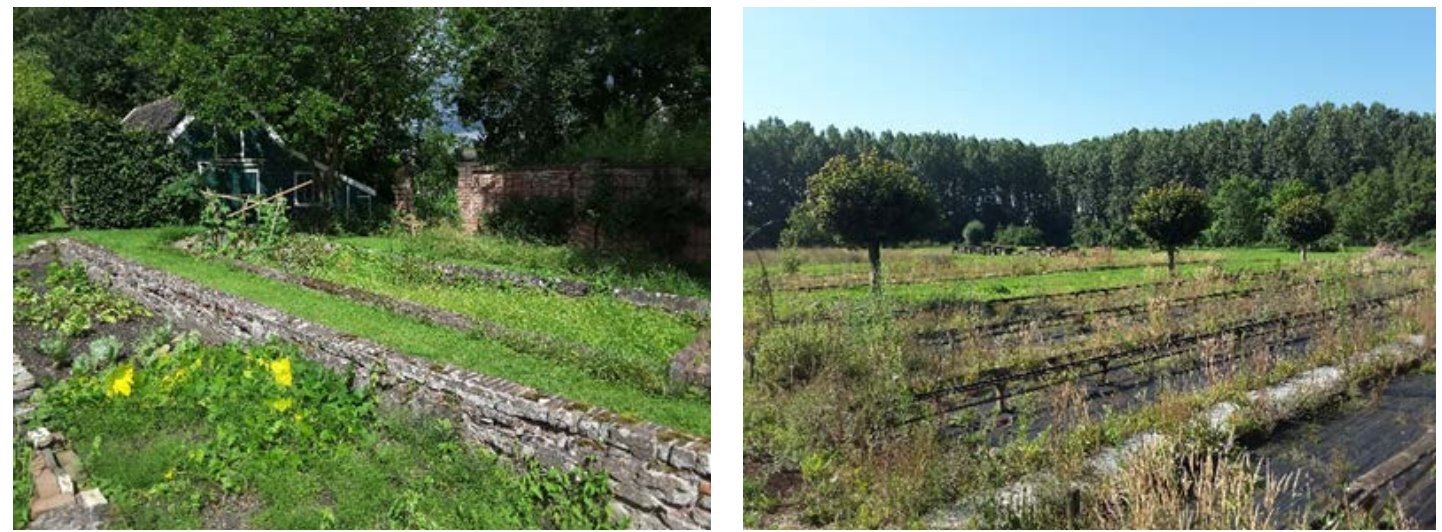

Figuur 23 Twee moestuinen in een matige tot slechte onderhoudsstaat. 

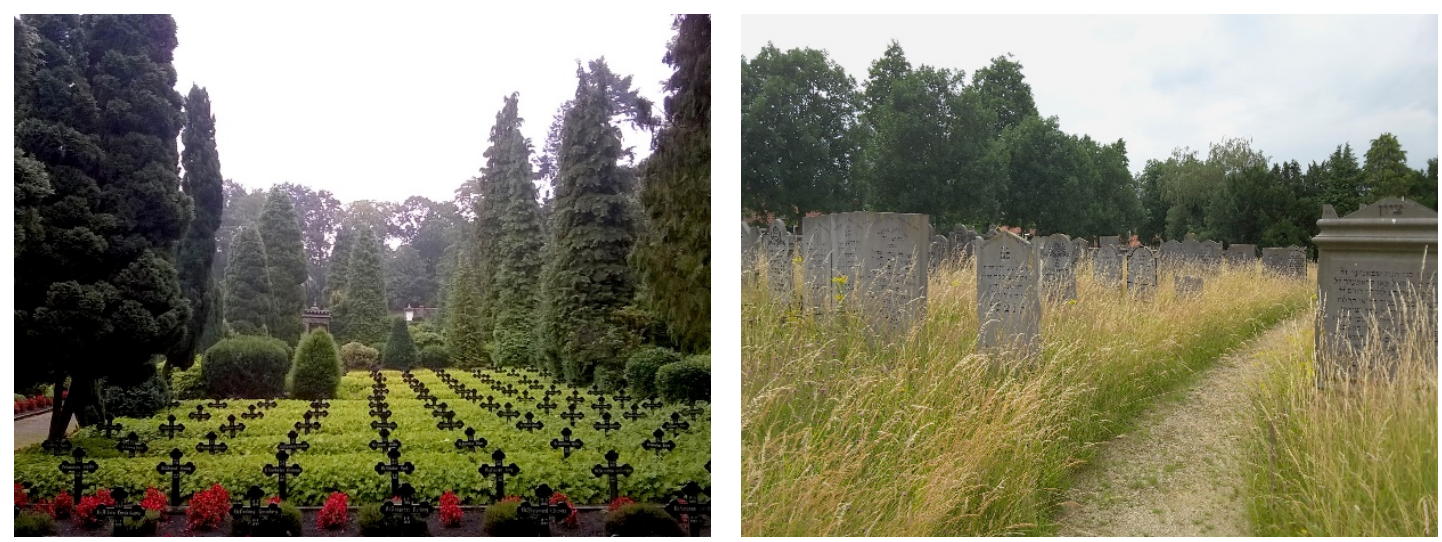

Figuur 24 Goed onderhouden kerkhoven en begraafplaatsen met waardevolle historische uniciteit.
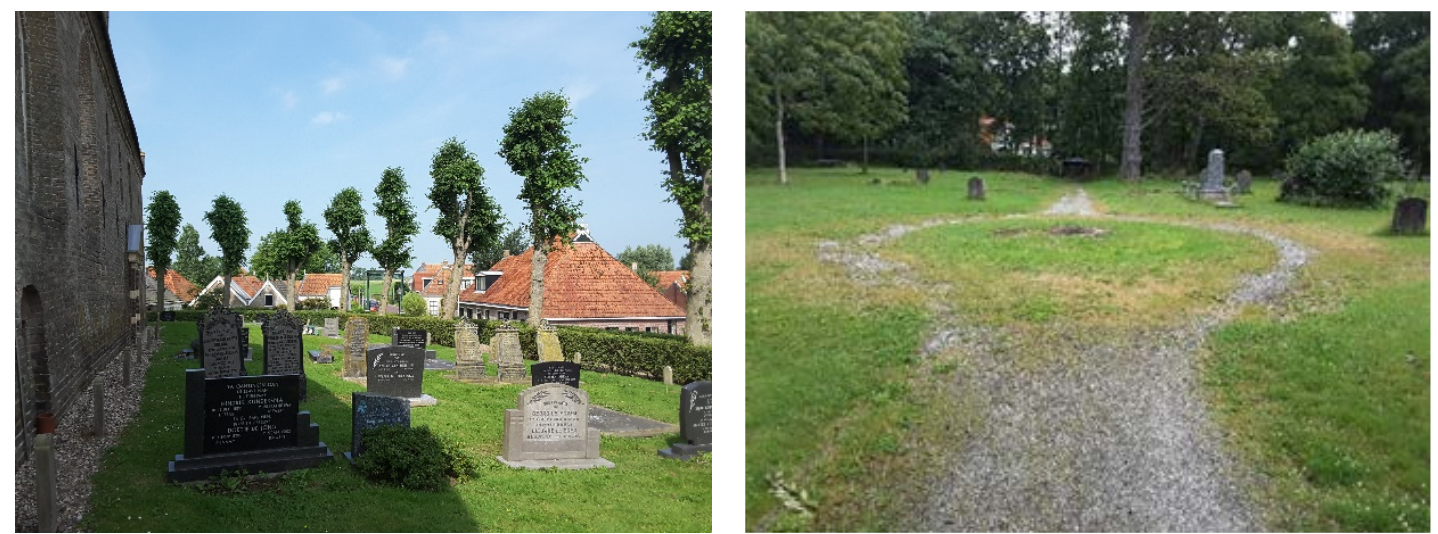

Figuur 25 Redelijke onderhoudsstaat naast een matige onderhoudsstaat bij kerkhoven en begraafplaatsen.
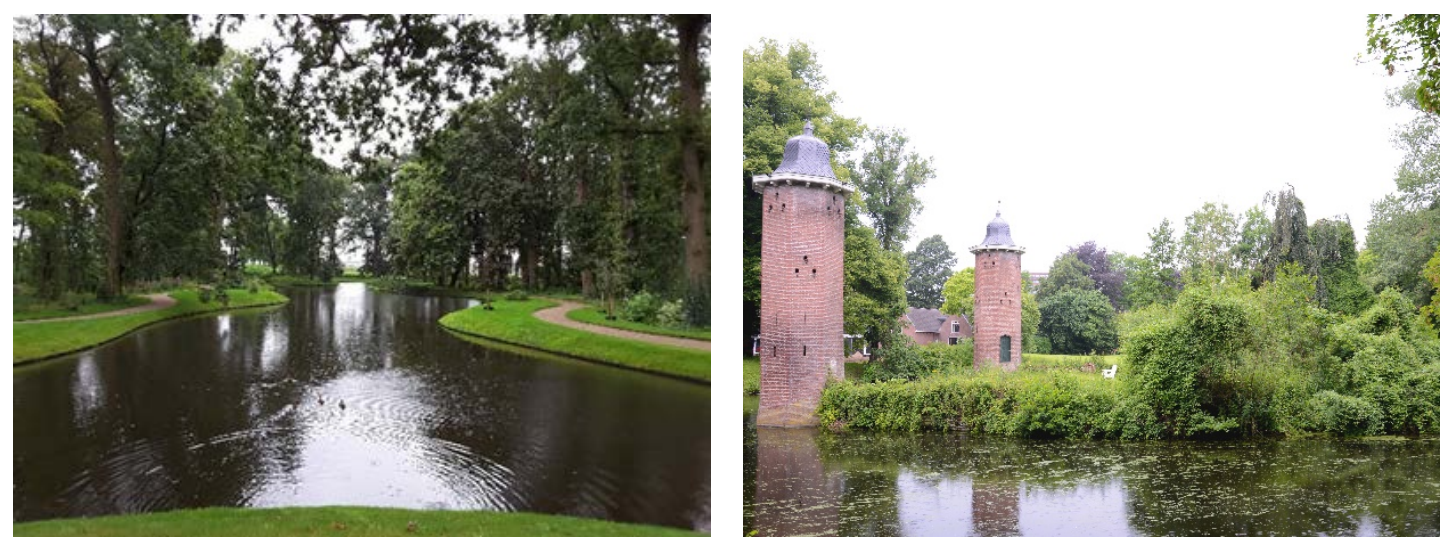

Figuur 26 Links een oever in goede onderhoudsstaat en rechts een oever in slechte onderhoudsstaat met een verwilderde begroeiing. 

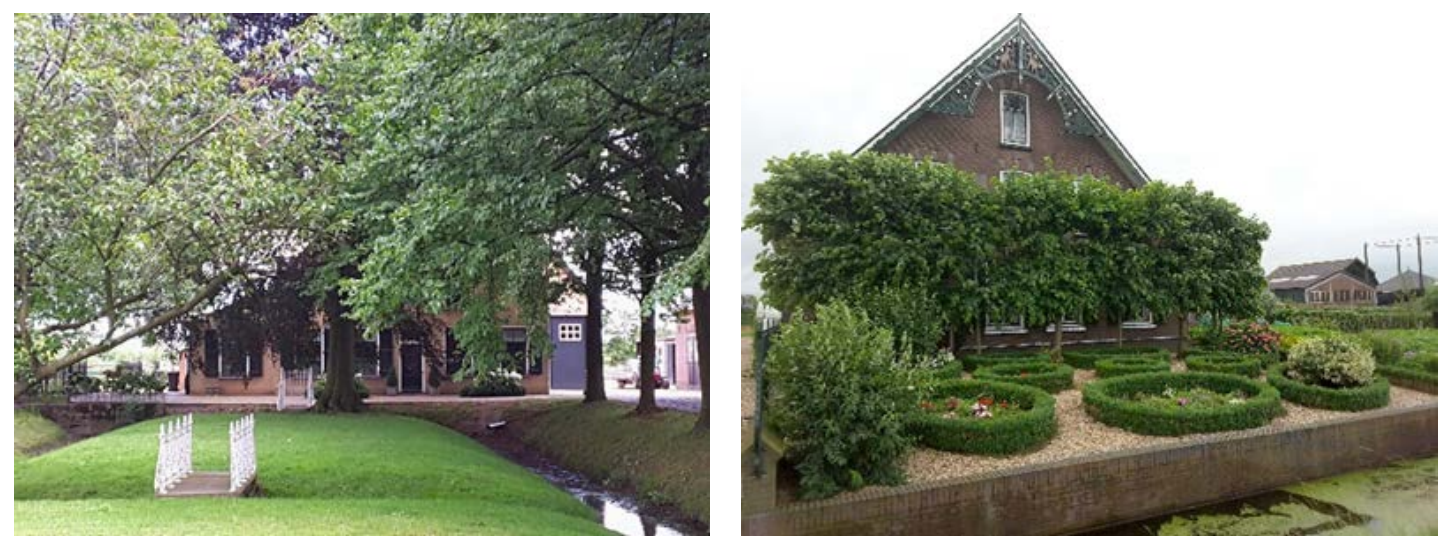

Figuur 27 Particuliere boerenerven in een goede onderhoudsstaat.
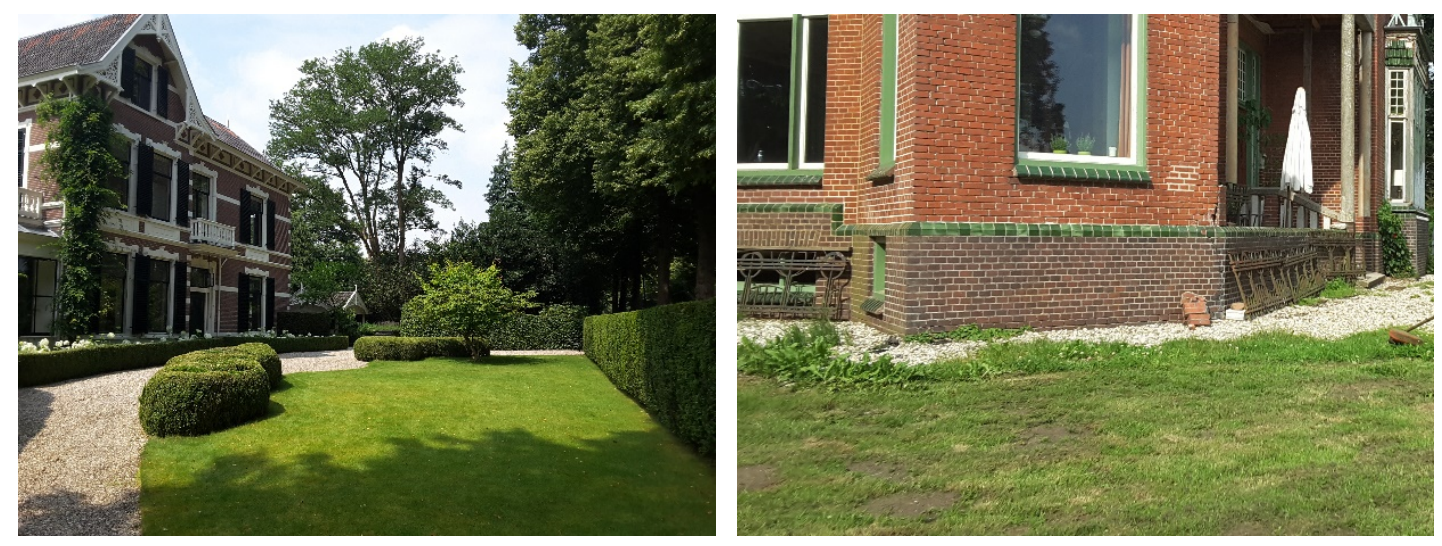

Figuur 28 Links een villatuin in een goede onderhoudsstaat en rechts een tuin in een matige onderhoudsstaat.

\subsection{Informatielacunes bij eigenaren}

In hoofdstuk 2 is geconstateerd dat groen erfgoed de afgelopen jaren als zelfstandige discipline op de kaart is gezet en dat een aantal platforms is opgericht voor de uitwisseling van kennis en ervaringen tussen eigenaren en andere betrokkenen (bladzijde 15). Interviews met eigenaren vormden geen onderdeel van de taakstelling van dit onderzoek. Toch is er in een inventarisatie als deze altijd een zekere 'bijvangst' in de vorm van informatie die eigenaren met de onderzoekers hebben gedeeld. Een van de opvallendste zaken die daaruit naar voren kwam, was dat vooral onder de particuliere eigenaren lang niet iedereen bekend is met het bestaan van de kennisplatforms rond groen erfgoed. Tegelijkertijd lijken veel eigenaren behoefte te hebben aan het delen van kennis en ervaringen met andere eigenaren. Onze indruk is dat de kennisplatforms die hiervoor in aanmerking komen momenteel vooral bekend zijn bij - en bezocht worden door - ambtenaren, adviseurs en terreinbeherende organisaties. Aanbevolen wordt dat de bestaande kennisplatforms via de RCE en de eigen vertegenwoordigende organisaties met regelmaat opnieuw onder de aandacht worden gebracht van de diverse categorieën eigenaren van groen erfgoed, in het bijzonder particulieren.

Een kleiner deel van de eigenaren bleek niet te weten dat de groenaanleg beschermd is, of hoe de begrenzing van de beschermde aanleg precies is. 


\section{$7 \quad$ Conclusies en aanbevelingen}

In welke staat verkeert de beschermde groenaanleg van Nederlandse rijksmonumenten en welk bedrag is nodig voor het onderhoud ervan? De minister van Onderwijs, Cultuur en Wetenschap heeft de Tweede Kamer toegezegd een onderzoek te laten uitvoeren om deze vragen te beantwoorden. Dit rapport presenteert de resultaten en conclusies van deze studie.

Om de onderzoeksvragen te kunnen beantwoorden, is uit de totale populatie van ongeveer 1.400 groene rijksmonumenten een steekproef getrokken van 209 objecten. Deze 209 objecten zijn in het veld met behulp van een GIS-app (geografisch informatie systeem) geïnventariseerd. Door gebruik te maken van deze softwareapplicatie zijn alle data direct ruimtelijk en digitaal vastgelegd. Binnen elk geïnventariseerd object zijn de globale afmetingen van de aanwezige groenelementen vastgelegd. Ook is de onderhoudsstaat van de aanwezige groenelementen met behulp van een beeldkwaliteitsdocument op een gestandaardiseerde en herhaalbare manier beoordeeld. Daarbij zijn vier onderhoudsklassen onderscheiden: goed, redelijk, matig en slecht.

De onderhoudsstaat is niet alleen op het niveau van de groenelementen vastgesteld, maar ook op objectniveau. Centraal in dit rapport staat de methode waarbij de onderhoudsstaat van een object is bepaald door de modale waarde te nemen van de onderhoudsstaat van de afzonderlijke groenelementen binnen het object. Als tweede methode is bij de bezochte objecten tevens de onderhoudsstaat van het object als geheel opgenomen in een directe visuele schatting na afloop van het veldwerk.

Aan de berekening van de onderhoudskosten voor de diverse groenelementen liggen de kengetallen uit de Leidraad subsidiabele instandhoudingskosten 2013 en het RCE-standaardbegrotingsmodel groen versie 8-9-2015 ten grondslag. Normen voor tijd en kosten zijn overgenomen uit het standaardbegrotingsmodel. Ook is gebruikgemaakt van prioritering van elementtypen zoals genoemd in de Leidraad. Prioriteit 1 betreft groenelementen die behoren tot de hoofdstructuur en aantoonbare kernwaarden van het groene monument. Prioriteit 2 betreft groenelementen die niet subsidiabel zijn vanuit de Subsidieregeling instandhouding monumenten (Sim). Daarnaast zijn in deze studie (groen)elementen onderscheiden die bij het groene monument horen maar niet onder prioriteit 1 of 2 vallen. Denk hierbij aan bouwland, natuur- of productiebos en gebouwen. In de veldinventarisatie is de omvang en de onderhoudsstaat van deze elementtypen niet opgenomen. Ook zijn deze elementtypen niet meegenomen in de berekening van de onderhoudskosten.

De onderhoudskosten zijn berekend uitgaande van een redelijke onderhoudsstaat en op basis van de onderhoudsfrequenties zoals opgenomen in de Leidraad. Waar het op basis van deskundigenoordeel nodig werd geacht om voor sober en doelmatig onderhoud van de frequenties af te wijken, is dit afzonderlijk in beeld gebracht.

De omvang van de restauratieopgave van het rijksbeschermde groene erfgoed in Nederland is in deze studie buiten beschouwing gelaten. Dit geldt ook voor het historische referentiebeeld van de groenaanleg van de onderzochte objecten. Onderhoudskosten voor elementen die wellicht in sommige objecten zijn verdwenen of omgevormd, zijn in deze studie dan ook niet meegenomen.

Aanvullend is in deze studie onderzocht of in de omschrijving van het rijksmonument de beschrijving van het type aanleg van de geïnventariseerde objecten klopt met de situatie in het veld. Waargenomen afwijkingen zijn gecategoriseerd vastgelegd.

De resultaten van dit onderzoek zijn op steekproefniveau ingedeeld naar categorie groen erfgoed, categorie eigenaar, provincie en type groenelement. Voor zover mogelijk en zinvol vanuit de steekproefopzet zijn deze indelingen ook toegepast bij de vertaling van de resultaten naar heel Nederland. 
De conclusies van deze studie worden in de volgende paragraaf beschreven en ingedeeld in twee groepen. Eerst komen de conclusies aan bod op het niveau van alle groene rijksmonumenten in Nederland. Deze conclusies komen voort uit een vertaalslag van de onderzoeksresultaten naar alle rijksbeschermde groene monumenten in Nederland. Daarna beschrijven we de conclusies op het niveau van de steekproef. Doordat de resultaten op diverse manieren zijn onderverdeeld en uitgesplitst, zouden op veel onderdelen omvangrijke deelconclusies mogelijk zijn. Om de tekstomvang binnen de perken te houden, richten we ons bij sommige conclusies op de meest in het oog springende bevindingen.

\subsection{Conclusies}

Op het niveau van alle circa 1.400 groene rijksmonumenten in Nederland concluderen wij:

1. Onderhoudsstaat: De onderhoudsstaat van het groene erfgoed in Nederland is overwegend redelijk. Van alle objecten is $20 \%$ in een goede staat en $69 \%$ in een redelijke staat, terwijl $11 \%$ matig scoort. Wel varieert het beeld van de onderhoudsstaat tussen individuele typen groenelementen en tussen categorieën groen erfgoed. Bij de groenaanleg bij medische en sociale instellingen, bij stadstuinen en bij villatuinen valt minstens de helft van de objecten in de categorie goed. Aan de andere kant is bij pastorietuinen, tuinen bij parken en landhuizen en tuinen bij bedrijven, overheden en organisaties sprake van een aanzienlijk aantal objecten met de onderhoudsstaat matig (respectievelijk 50\%, 33\% en 25\%).

2. Onderhoudskosten: De totale kosten voor het onderhoud van het rijksbeschermde groene erfgoed in Nederland bedragen $€ 132$ miljoen per jaar. Dit is incl. 38\% indirecte kosten, waaronder btw. Ook is dit uitgaande van sober en doelmatig onderhoud volgens de Leidraad voor zowel Prioriteit 1 als Prioriteit 2. Verreweg het grootste aandeel van de totale geschatte onderhoudskosten $(78 \%)$ komt voor rekening van de categorie groenaanleg bij buitenplaatsen en landgoederen.

3. Regionale spreiding onderhoudskosten: Het grootste aandeel in de onderhoudskosten hebben de groene rijksmonumenten in West-Nederland (42\%) en Oost-Nederland (37\%). In deze landsdelen liggen naar verhouding veel objecten met hoge onderhoudskosten in de categorie landgoederen en buitenplaatsen.

4. Onderhoudskosten bij afwijkende onderhoudsfrequenties: In aanvulling op de kostenberekening volgens de Leidraad is bij zeven van de 30 elementtypen afgeweken van de onderhoudsfrequenties volgens de Leidraad. Bij deze elementtypen zijn de onderhoudsfrequenties volgens de Leidraad onzes inziens niet toereikend voor sober en doelmatig onderhoud. Bij deze afwijkende onderhoudsfrequenties bedragen de totale onderhoudskosten van het rijksbeschermde groene erfgoed in Nederland $€ 185$ miljoen per jaar. Dit is incl. 38\% indirecte kosten, waaronder btw. Van de meerkosten ten opzichte van het bedrag uitgaande van onderhoudsfrequenties volgens de Leidraad komt 65\% ( $€ 34$ miljoen) voor rekening van het elementtype gazon.

5. Aandeel prioriteit $\mathbf{2}$ in onderhoudskosten: De jaarlijkse onderhoudskosten (incl. indirecte kosten en btw) van elementtypen met prioriteit 2 bedragen $7 \%$ van de totale jaarlijkse onderhoudskosten (prioriteit $1+2$ ), als we ervan uitgaan dat alle potentiële kernwaardeelementen ook aantoonbaar kernwaarden zijn. Uitgaande van frequenties voor sober en doelmatig onderhoud op basis van deskundigenoordeel van de auteurs (deze frequenties zijn hoger dan die volgens de Leidraad) is dit $5 \%$.

6. Methodiek: De methodiek voor de inventarisatie van de onderhoudsstaat en onderhoudskosten van groen erfgoed biedt door zijn gestandaardiseerde en herhaalbare opzet (onder meer door gebruik van een beeldkwaliteitsdocument en een app voor de veldinventarisatie) een basis voor toekomstige monitoring van groen erfgoed. 
Op het niveau van de geïnventariseerde steekproef van 209 objecten concluderen wij:

7. Onderhoudsstaat naar categorie groen erfgoed, eigenaar en provincie: Voor de onderhoudsstaat op basis van de steekproef komen voor de indeling naar categorie groen erfgoed, categorie eigenaar en provincie geen duidelijke verschillen naar voren.

8. Onderhoudskosten naar categorie eigenaar: De jaargemiddelde onderhoudskosten voor alle in de steekproef onderzochte objecten en elementtypen samen bedragen $€$ 19.761.486. Bijna de helft van de objecten in de steekproef is in particuliere handen, waardoor deze categorie de hoogste totale onderhoudskosten heeft. Qua jaarlijkse totale kosten komen de terreinbeherende organisaties op de tweede plaats, hoewel ze maar $11 \%$ van de objecten in de steekproef in eigendom hebben. Dit kan worden verklaard door de gemiddelde kosten per object, die bij de terreinbeherende organisaties veel hoger zijn dan bij de overige categorieën eigenaar. In verhouding tot andere categorieën eigenaren beheren de terreinbeherende organisaties relatief grote objecten.

9. Onderhoudskosten per provincie: Op basis van de steekproef kennen Gelderland, Utrecht en Noord-Holland de hoogste jaarlijkse onderhoudskosten voor rijksbeschermd groen erfgoed. Deze provincies herbergen samen $41 \%$ van alle objecten in de steekproef. Ook de onderhoudskosten per object zijn het hoogst in deze drie provincies. Dit komt doordat de twee categorieën groen erfgoed met de hoogste onderhoudskosten in deze drie provincies oververtegenwoordigd zijn: de helft van de stadsparken en plantsoenen en meer dan de helft van de buitenplaatsen en landgoederen uit de steekproef liggen in Gelderland, Utrecht en Noord-Holland.

10. Relatie tussen onderhoudsstaat en onderhoudskosten: Op het niveau van elementtypen is geen verband tussen beide vastgesteld. Als de onderhoudsstaat en onderhoudskosten op objectniveau met elkaar in verband worden gebracht, blijkt er een tendens te zijn dat objecten in een gemiddeld slechtere staat duurder zijn in de totale onderhoudskosten. Dit komt mogelijk doordat deze objecten groter zijn en niet doordat in deze objecten meer elementtypen met hoge onderhoudskosten per hectare aanwezig zijn. Juist objecten die per eenheid oppervlakte relatief hoge onderhoudskosten vragen, verkeren in een goede onderhoudsstaat. Omdat de daadwerkelijk gemaakte onderhoudskosten en de beweegredenen van eigenaren niet zijn onderzocht, is een verklaring voor dit patroon moeilijk te geven.

11. Aanvullende onderhoudskosten uitgezonderde elementtypen: Zeven geïnventariseerde elementtypen worden wel in de Sim genoemd, maar zijn niet in de Leidraad als subsidiabel aangemerkt en niet in de gestandaardiseerde kostenberekening meegenomen. Voor deze elementtypen is op basis van andere bronnen een aanvullende schatting gemaakt van de onderhoudskosten. Voor de zeven elementtypen samen bedragen de aanvullende jaargemiddelde onderhoudskosten $€ 2.779 .488$. Dit is $14 \%$ van de totaal geschatte kosten op steekproefniveau.

12. Onderhoudsstaat op objectniveau: De verdeling van de scores over de vier klassen van onderhoudsstaat is gelijkmatiger bij de veldschatting (34\% van de objecten goed, $35 \%$ redelijk, $25 \%$ matig, 6\% slecht) dan bij de uit de elementscores berekende modale waarde (20\% goed, $69 \%$ redelijk, 11\% matig). De beste van de twee methoden is de berekening van de modale onderhoudsstaat op basis van de staat van de aanwezige elementen. Bij deze methode bestaat niet het risico dat de onderhoudsstaat van bepaalde elementtypen onbewust zwaarder of minder zwaar wordt meegewogen in het oordeel. Ook past deze methode beter bij het doel van een gestandaardiseerde, objectieve en herhaalbare aanpak.

13. Afwijkingen van de omschrijving van het rijksmonument: Van de 209 bezochte objecten werd in $44 \%$ van de gevallen een afwijking geconstateerd van de aangetroffen situatie ten opzichte van de omschrijving. In $77 \%$ van de objecten met een afwijkende omschrijving was sprake van een ontbrekende beschrijving van de aanlegstijl. In $30 \%$ van de objecten met een afwijkende omschrijving was sprake van verdwenen of aangetaste groenelementen. Hierbij wordt aangetekend dat de omschrijvingen vaak enkele decennia geleden zijn opgesteld en daardoor geen actueel beeld kunnen geven. Bovendien zijn ze bedoeld ter identificatie van het beschermde en niet als volledige omschrijving daarvan. Ook verschillen de omschrijvingen van object tot object sterk in omvang en detaillering. Sommige omschrijvingen zijn uitermate summier, andere vrij uitgebreid met veel aandacht voor individuele elementen in de groenaanleg. 


\subsection{Aanbevelingen}

Op basis van dit onderzoek wordt aanbevolen:

1. Herhaal dit onderzoek periodiek en pas dit toe op alle groene rijksmonumenten: Hierdoor kunnen verschillen tussen categorieën groen erfgoed en ontwikkelingen in de tijd objectief worden vastgesteld en handelingsperspectieven voor de betrokken partijen worden geformuleerd.

2. Onderzoek oorzaken en oplossingsrichtingen voor slechter scorende categorieën groen erfgoed: Dit geldt bijvoorbeeld voor de categorieën pastorietuinen, tuinen bij parken en landhuizen en tuinen bij bedrijven, overheden en organisaties waarin bovengemiddeld veel objecten met een matige modale onderhoudsstaat voorkomen.

3. Verricht nader onderzoek naar de relatie tussen onderhoudsstaat en onderhoudskosten en betrek daarbij het historische referentiebeeld van de groenaanleg in de inventarisatie: Vergelijk ook de onderhoudsstaat op objectniveau met de eventuele afwijkingen van de omschrijving van het rijksmonument. Zo wordt duidelijk of door verschraling van het beheer historische elementen zijn verdwenen of omgevormd, wordt meer inzicht verkregen in de restauratieopgave en kan een betere schatting worden gemaakt van de onderhoudskosten.

4. Verhoog bij $\mathbf{7}$ van de $\mathbf{3 0}$ beschouwde elementtypen de normfrequentie voor sober en doelmatig onderhoud: Dit speelt het sterkst bij gazons, waar volgens de Sim 2x maaien per jaar subsidiabel is en dat volgens deskundigenonderdeel van de auteurs $24 x$ per jaar zou moeten zijn voor sober en doelmatig onderhoud. Verder is dit aan de orde bij aardwerken en graspaden (hogere maaifrequentie), bij heesterborders, heestergroepen en verharde paden (vaker onkruidvrij houden) en bij kuipplanten.

5. Maak voor de groene rijksmonumenten een uitgebreidere omschrijving (als kennisdeel bij het register): Dit zou kunnen door gerichte veldwaarnemingen en door informatie uit onderzoeks- en adviesrapporten te gebruiken, vergelijkbaar met het gebruik van PHB-rapporten in het verleden.

6. Breng de restauratiebehoefte van het rijksbeschermde groene erfgoed in kaart: In deze studie is gekeken naar de onderhoudsbehoefte. Voor duurzame instandhouding van het groene erfgoed is echter ook de restauratiebehoefte van belang.

7. Breng de omvang van externe effecten op onderhoudsstaat en onderhoudskosten in beeld: Groene monumenten hebben te maken met de gevolgen van externe factoren zoals klimaatverandering en beleid vanuit andere sectoren (zoals milieubeleid rond bestrijdingsmiddelen). Aanbevolen wordt in een vervolgonderzoek te kwantificeren welke gevolgen deze externe factoren hebben voor de onderhoudsstaat en onderhoudskosten.

8. Breng bestaande kennisplatforms beter onder de aandacht van eigenaren: Uit gesprekken met eigenaren komt naar voren dat vooral onder de particuliere eigenaren lang niet iedereen bekend is met het bestaan van de kennisplatforms rond groen erfgoed. Tegelijkertijd lijken veel eigenaren behoefte te hebben aan het delen van kennis en ervaringen met andere eigenaren. Aanbevolen wordt na te gaan hoe de diverse categorieën eigenaren van groen erfgoed, in het bijzonder particulieren, de bestaande kennisplatforms beter kunnen vinden. Dit draagt bij aan de versterkte ontwikkeling van een leernetwerk instandhouding groen erfgoed.

9. Neem belangrijke indelingscategorieën mee in de steekproefopzet: Bij een volgende inventarisatieronde is aan te bevelen om uit te gaan van een gestratificeerde steekproef waarbij in de stratificatie niet alleen de categorie groen erfgoed wordt gebruikt, maar ook de categorie eigenaar en de provincies. Dit maakt het makkelijker om op landelijk niveau heldere conclusies te trekken over verschillen binnen deze indelingscategorieën. Het betekent mogelijk wel dat de omvang van de steekproef zou moeten toenemen. Objecten uit de steekproef die afvallen, bijvoorbeeld omdat een eigenaar geen toestemming geeft, kunnen het best worden vervangen door een vervangend object in te loten vanuit hetzelfde stratum (bijv. categorie groen erfgoed).

10. Optimaliseer de GIS-app voor toekomstige herhaling van het onderzoek: Dit kan door de invoeropties van de app verder te verbeteren, de app gebruikersvriendelijker en beschikbaar te maken. Dit betekent onder meer dat de app moet worden voorzien van toelichtende gebruiksinformatie en dat niet-relevante invoeropties worden uitgesloten. 


\section{Literatuur}

Bomenstichting e.a., Declaratie van Arnhem, Arnhem 7 oktober 1999.

Carpentier, F., e.a., Behoud historisch buitenplaatsen in Limburg, Een vergelijkend onderzoek tussen Nederland, Vlaanderen en Duitsland, z.pl. 2013.

D'Ancona, H., 'RV-1a-Brhb, Hoofdstuk II De nieuwe regeling', WR blad 06-2, 1993.

Debie \& Verkuijl, 2016. Catalogus Beeldkwaliteit Groen Erfgoed. Debie \& Verkuijl tuin park landschap, Renswoude.

Donner, J.P.H., Besluit van 16 januari 2006, houdende regels met betrekking tot de financiële ondersteuning van eigenaren van beschermde monumenten ten behoeve van de instandhouding van beschermde monumenten (Besluit rijkssubsidiëring instandhouding monumenten), Staatsblad (31 januari 2006) nr. 31.

Herwaarden, G. van en K. Sluyterman van Loo, 'Hoe wordt 'Arcadië' beschermd', in: H.W. van Heerwaarden (red) e.a., Jaarboek Monumentenzorg 1998. Buitenplaatsen, Zwolle 1999.

ICOMOS, International Charter for the conservation and restauration of monuments and sites (The Venice Charter 1964), Venice 1965.

ICOMOS-IFLA International Committee for Historic Gardens, Historic gardens, The Florence Charter 1981, Florence 1982.

Kamerlingh Onnes, H.M.A. 'De bescherming van historische buitenplaatsen op Europees niveau', in: G.W. van Herwaarden, e.a., Jaarboek Monumentenzorg 1988, Buitenplaatsen, Zwolle 1999, pp. 16-17.

Lohr, S.L. 1999. Sampling: Design and Analysis. Duxbury Press, Pacific Grove.

Moraal, L.G., e.a., Verschuivingen van insectenplagen bij bomen sinds 1946 in relatie met klimaatverandering; Met aandacht voor de effecten van stikstofdepositie, vochtstress, bossamenstelling en bosbeheer. Wageningen, Alterra-rapport 856, 2004.

RCE, 2012. Een toekomst voor groen. Handreiking voor de instandhouding van groene monumenten. Amersfoort, Rijksdienst voor het Cultureel Erfgoed, 74 p. URL: http://cultureelerfgoed.nl/sites/default/files/publications/een-toekomst-voor-groen_0.pdf.

RCE, 2014. Eenheid en verscheidenheid, een zoektocht naar een integrale cultuurhistorische waardestelling van het materiële erfgoed. Amersfoort, Rijksdienst voor het Cultureel Erfgoed, $19 \mathrm{p}$.

Ruijgrok, E.C.M., 2012. Economische betekenis van historische buitenplaatsen en landgoederen in de provincies Utrecht, Overijssel en Gelderland. Rapport in opdracht van de provincies Utrecht, Overijssel en Gelderland. Bureau Witteveen en Bos, 56 p. + bijlagen.

Ruijgrok, E.C.M., 2015. Particuliere instandhouding van historische buitenplaatsen. Rapport in opdracht van de Vereniging Particuliere Historische Buitenplaatsen. Bureau Witteveen en Bos, $43 \mathrm{p}$.

SNL, 2016. Standaardkostprijs directe werkzaamheden terreinbeheer voor gezamenlijke TBO's. Staatsbosbeheer, $133 \mathrm{p}$.

Verburg, G., (Ministerie van Landbouw, Natuur en Voedselkwaliteit), Brief aan Voorzitter van de Tweede Kamer der Staten-Generaal betreffende verzelfstandiging van de stichting PHB, ref.nr. DN.2009-1187, 22 juni 2009.

Weekers, F.H.H., Besluit btw-verlaging van 28 februari 2013, Staatscourant nr. BLKB/2013/305M. http://cultureelerfgoed.nl/nieuws/545-miljoen-euro-voor-instandhouding-rijksmonumentenWerkgroep Brim evaluatie 2011.

Zijlstra, H., 'Besluit rijkssubsidiëring instandhouding monumenten 2013, nr. 438', Staatsblad 2012, (19 september), 2012a.

Zijlstra, H., 'Regeling van de Staatssecretaris van Onderwijs, Cultuur en Wetenschap van 19 september 2012, nr. WJZ/387165 (10152)', Staatscourant 20420 (9 oktober), 2012b. 


\section{Bijlage 1 Begrippenlijst}

\section{Begraafplaats}

Begraafplaatsen zijn terreinen waar stoffelijke resten van overledenen begraven, bijgezet of verstrooid worden. Een terrein dat één geheel vormt met de bedrijfsgebouwen in een ontworpen tuin- en parkaanleg, waarin de begraven doden zijn ingepast. Een begraafplaats ligt niet rondom een kerk en onderscheidt zich daarmee van een kerkhof.

\section{Boerenerf}

Boerenerven zijn verharde of onverharde erven direct om een boerderij gelegen. Ze bieden ruimte voor activiteiten en opslag die bij de boerderij horen, zoals een dorsvloer, stallen, hokken en schuren maar ook tuinen, boomgaarden en geriefhout. Een boerenerf toont haar gebruiksgeschiedenis met een landschapsensemble dat bestaat uit de historische bedrijfsgebouwen en de kleine gebouwde objecten op het erf om de boerderij, met groene erfbeplanting in de traditionele indeling van voor-, zij- en achtererf en aanwezige waterelementen.

\section{Bolletjeskaart}

De bolletjeskaart geeft de contour aan van een specifiek beschermd gebied van de aanleg van de tuin of het park, bij rijksmonumentale buitenplaatsen. De beschermde aanleg staat beschreven in het Monumentenregister dat de Rijksdienst bijhoudt (www.cultureelerfgoed.nl/monumentenregister). Samen met Kadastergegevens blijkt welke percelen bescherming genieten. Op een bolletjeskaart is te zien of een perceel geheel of gedeeltelijk beschermd is.

\section{Buitenplaats}

Een buitenplaats is een monumentaal huis (zoals een kasteel, buitenhuis of landhuis), dat samen met eventuele bijgebouwen één geheel vormt met de omringende tuinen of parkaanleg. Een buitenplaats kan deel uitmaken van een landgoed, maar er zijn ook veel buitenplaatsen zonder landerijen.

\section{Element(type)}

Elementen zijn de basiseenheden van een groenaanleg. De aanleg kan bestaan uit een of (meestal) meerdere elementen. De elementen kunnen worden ingedeeld in elementtypen, zoals fruitbomen, parkweiden, waterlopen en beschoeiingen. Op basis van hun verschijningsvorm kunnen puntvormige, lijnvormige en vlakvormige elementen en elementtypen worden onderscheiden.

\section{Erfgoedwet}

De Erfgoedwet 2016 bundelt bestaande wet- en regelgeving voor behoud en beheer van het cultureel erfgoed in Nederland.

\section{Groen erfgoed}

Groen erfgoed is cultureel erfgoed bestaande uit een groenaanleg met cultuurhistorische, horticulturele of architectuurhistorische waarden, zoals een park, tuin, begraafplaats, boerenerf, verdedigingswerk, hortus botanicus en wijk- of wegbeplanting.

\section{Groen monument}

Een historische ruimtelijke compositie met ontworpen structuren die te onderscheiden zijn van hun ruimere omgeving. Hier is ook wel sprake van een beschermde groenaanleg.

\section{Historische aanleg}

Een architectonische en horticulturele compositie, van belang vanuit historisch en artistiek oogpunt. Een groenaanleg bestaat in ieder geval gedeeltelijk uit levende elementen en is daarmee aan verandering onderhevig. 


\section{Instandhoudingsbehoefte}

De som van de onderhoudsbehoefte en de restauratiebehoefte (zie aldaar).

\section{Kerkhof}

Een begrensd terrein rondom of nabij een kerk waarin de begraven doden zijn ingepast.

\section{Monument}

Een onroerend goed (gebouw, groenaanleg of object) dat beschermd is geregistreerd door Rijk, provincie of gemeente. Onder monumenten vallen ook gebouwen, aanleggen en objecten die voorbescherming als monument genieten.

\section{Object}

Onder object verstaan we in dit rapport de rijksbeschermde groenaanleg van bijvoorbeeld landgoederen, buitenplaatsen, begraafplaatsen, stadsparken, villatuinen, etc. In het kader van dit rapport is een steekproef van 209 objecten verspreid over Nederland onderzocht.

\section{Omschrijving van het rijksmonument}

Voor de inwerkingtreding van de Erfgoedwet 2016 werd hiervoor het begrip registeromschrijving gebruikt (een nog oudere term is redengevende omschrijving). Het begrip heeft betrekking op de korte en de uitgebreide omschrijvingen van rijksmonumenten die tot aan Erfgoedwet registerteksten waren. Ze dienen ter duiding en identificatie van het beschermde monument en zijn vastgelegd in het rijksmonumentenregister (https://monumentenregister.cultureelerfgoed. $\mathrm{nl} /$ ). Met de Erfgoedwet zijn alleen de identificerende gegevens uit die lange teksten nog deel van het register. De rest zijn kennisgegevens.

\section{Onderhoudsbehoefte}

De jaargemiddelde kosten om de beschermde groenaanleg (van rijksmonumenten) door middel van sober en doelmatig onderhoud in een redelijke onderhoudsstaat te houden. In dit rapport noemen we de onderhoudsbehoefte meestal onderhoudskosten.

\section{Restauratiebehoefte}

De (jaargemiddelde) kosten om de beschermde groenaanleg (van rijksmonumenten) door middel van restauratie in een oorspronkelijke/historische staat terug te brengen.

\section{Restaureren}

Het uitvoeren van herstelwerkzaamheden aan gebouwen en aanleggen met monumentenstatus dan wel met een duidelijke cultuurhistorische waarde, die verder gaan dan normaal onderhoud en tot doel hebben het gebouw of de aanleg in goede staat te brengen met behoud van cultuurhistorische waarden.

\section{Rood erfgoed}

Historische gebouwen die worden beschermd door de rijksoverheid, provincie of gemeente vanwege hun cultuurhistorische karakter en waarde.

\section{Subsidieregeling instandhouding monumenten (Sim)}

De Subsidieregeling instandhouding monumenten ondersteunt sober en doelmatig onderhoud van monumenten. De subsidie is bedoeld voor het planmatig in goede staat houden van een monument. De subsidie richt zich op structureel onderhoud i.p.v. restauraties, zoals schilder- en herstelwerk. De eigenaar stelt daartoe een zesjarig instandhoudingsplan op met het vereiste begrotingsmodel. De Subsidieregeling instandhouding monumenten ( $\mathrm{Sim}$ ) is rechtstreeks op de Erfgoedwet gebaseerd. Het Besluit rijkssubsidiëring instandhouding monumenten 2013 (Brim 2013) is komen te vervallen. Een deel van de bepalingen uit het Brim 2013 is opgenomen in de Erfgoedwet en een ander deel is opgenomen in de Sim. 


\section{Type aanleg}

Onderdeel van een groenaanleg die op basis van vorm, stijl en aanlegperiode een eenheid vormt. Een aanlegtype bestaat op zijn beurt uit elementen. Binnen elke van de in dit rapport onderscheiden categorieën rijksbeschermde groenaanleg (zie Tabel 2 op bladzijde 22) kunnen een of meerdere typen aanleg worden onderscheiden.

\section{Veldinventarisatie}

In deze studie: op een steekproef gebaseerde terreinopnamen die de actuele situatie van groen erfgoed objecten beschrijven. Tijdens de veldinventarisatie zijn opgenomen: de aanwezige groenelementen met hun globale afmetingen en hun onderhoudsstaat. Ook is een schatting gemaakt van de onderhoudsstaat van het object als geheel. Ten slotte zijn afwijkingen ten opzichte van de omschrijving van het rijksmonument genoteerd. 


\section{Bijlage 2 Prioriteit en afwijkende onderhoudsfrequentie per elementtype}

Geïnventariseerde typen groene elementen met de in deze studie gehanteerde prioriteit.

\begin{tabular}{|c|c|}
\hline Elementtype & Prioriteit \\
\hline Eenvoudige houten loopbruggetjes & 1 \\
\hline Paden en wegen (verhard) & 1 \\
\hline Zichtassen en zichtlijnen & 1 \\
\hline Hagen ( $1 \mathrm{x}$ snoeien) & 1 \\
\hline Berceaus & 1 \\
\hline Leifruit & 1 \\
\hline Heesterborders & 1 \\
\hline Parkbosrand & 1 \\
\hline Hagen ( $2 x$ snoeien) & 1 \\
\hline Beschoeiing & 1 \\
\hline Gazons & 1 \\
\hline Heestergroepen & 1 \\
\hline Paden en wegen (half-/onverhard) & 1 \\
\hline Topiaria & 1 \\
\hline Solitaire bomen en boomgroepen & 1 \\
\hline Parkweiden & 1 \\
\hline Laanbomen & 1 \\
\hline Paden (gras) & 1 \\
\hline Bermen & 1 \\
\hline Gras langs waterlopen & 1 \\
\hline Waterpartijen en waterlopen & 1 \\
\hline Fruitbomen & 1 \\
\hline Boomsingel & 1 \\
\hline Ruigten in parkbos & 1 \\
\hline Leibomen en knotbomen & 2 \\
\hline Bloemperken & geen \\
\hline Rozenperken & 2 \\
\hline Vaste plantenborders & 2 \\
\hline Kuipplanten & 2 \\
\hline Aardwerken & 1 \\
\hline Hakhout & 2 \\
\hline Klimplanten & 2 \\
\hline Moestuin & geen \\
\hline Houtwal en houtsingel & geen \\
\hline Parkbos & 2 \\
\hline Bouwland & geen \\
\hline Gebouw & geen \\
\hline Bos (productie- of natuurbos) & geen \\
\hline Overig & geen \\
\hline
\end{tabular}




\section{Elementtypen waarvoor een afwijkende frequentie voor sober en doelmatig onderhoud is} gehanteerd: overzicht en toelichting

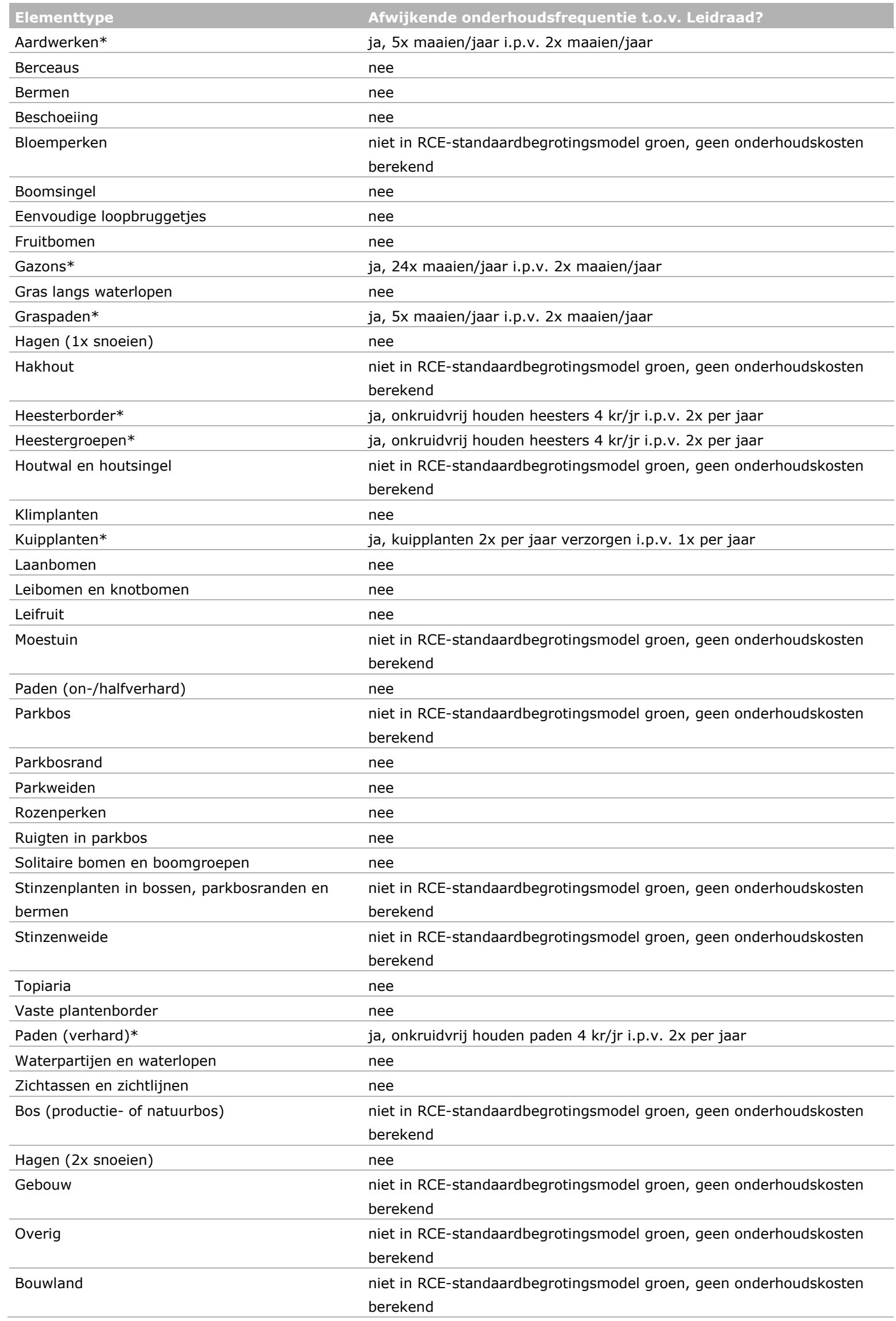

\footnotetext{
* Elementtypen waarbij Totaal kosten afwijkend > Totaal kosten Leidraad
} 


\section{Aardwerken}

De maaifrequentie is verhoogd van twee tot vijf keer per jaar maaien om twee redenen. Ten eerste wordt de vorm van de aardwerken beter waargenomen als het gras niet te lang is. Wanneer slechts twee keer per jaar gemaaid wordt, groeit het gras te lang uit. Ten tweede wordt door een hogere maaifrequentie de ontwikkeling van een dichtere grasmat bevorderd. Hierdoor neemt het risico van erosie en afspoeling van de aardwerken af.

\section{Gazons}

Het gewenste beeld van een gazon is een homogene, kort gemaaide grasmat zonder onregelmatigheden en ongewenste ingroei van andere kruiden. Bij twee keer per jaar maaien wordt dit beeld niet gerealiseerd. Het gras wordt te hoog en er ontstaat een weilandbeeld. Door 24 keer per jaar te maaien, wordt het gewenste beeld wel gerealiseerd.

\section{Heesterborders, heestergroepen}

Heestergroepen en heesterborders dienen een net beeld te hebben met geen of weinig ongewenste ingroei van onkruiden. Dit beeld wordt verkregen door de beplantingen vier keer per jaar onkruidvrij te maken. Als onkruidvrij maken twee keer per jaar plaatsvindt, zal er te veel ongewenste ingroei zijn en krijgen de onkruiden de kans zich uit te zaaien en te vermeerderen. Dit is niet wenselijk en zal per onderhoudsronde meer arbeid vergen om een net beeld te behouden.

\section{Kuipplanten}

Kuipplanten zijn vaak beeldbepalende elementen in een historische tuin en dienen van een goede kwaliteit te zijn. Dit wordt bereikt door deze kuipplanten twee keer per jaar te snoeien en onkruidvrij te maken.

\section{Paden verhard}

Verharde paden in groen erfgoed bestaan vaak uit relatief fijne materialen, zoals klinkers, waar veel onkruid tussen kan groeien. Dit dient vier keer per jaar verwijderd te worden, zodat er een verzorgd beeld ontstaat. Zo kunnen de onkruiden niet groot worden en zich uitzaaien, iets wat bij een lagere onderhoudsfrequentie wel zal gebeuren. 


\section{Bijlage 3 Toelichting kostenberekening onderhoud groenaanleg}

In deze bijlage wordt toegelicht welke stappen zijn doorlopen om de jaargemiddelde kosten van sober en doelmatig onderhoud van de beschermde groenaanleg bij rijksmonumenten in Nederland te kunnen berekenen.

\section{Twee aangepaste tabellen}

Als eerste stap zijn als afgeleide van het RCE-standaardbegrotingsmodel groen (d.d. 8-9-2015) twee tabellen gemaakt:

- Een tabel Freq_leidraad (Figuur 29), waarbij de onderhoudskosten worden berekend uitgaande van de frequenties voor sober en doelmatig onderhoud zoals voorgeschreven door de Leidraad subsidiabele instandhoudingskosten 2013/het RCE-standaardbegrotingsmodel groen.

- Een tabel Freq_afwijkend (Figuur 30), waarbij op basis van deskundigenoordeel bij 7 van de 30 elementtypen (zie Bijlage 2) is afgeweken van de door Leidraad/standaardbegrotingsmodel groen voorgeschreven onderhoudsfrequenties. Ook bij de in deze tabel gebruikte afwijkende frequenties was het uitgangspunt: sober en doelmatig onderhoud. Het gebruik van de afwijkende onderhoudsfrequenties heeft geleid tot een hoger bedrag aan berekende onderhoudskosten.

In de berekening worden beide tabellen naast elkaar gehanteerd, wat resulteert in twee totaalbedragen per object (en per elementtype binnen een object). Waar in het vervolg van dit document wordt verwezen naar de ene tabel (onderhoudsfrequenties volgens Leidraad) wordt tevens de andere tabel (afwijkende onderhoudsfrequenties) bedoeld, tenzij anders aangegeven.

\section{Koppeling elementtypen aan rekenregels onderhoudskosten}

Als tweede stap zijn de elementtypen zoals in dit project gehanteerd (in het beeldkwaliteitsdocument, in de kaarten van de groenaanleg, in de database; zie Bijlage 2), gekoppeld aan de rekenregels voor sober en doelmatig onderhoud zoals opgenomen in het RCE- standaardbegrotingsmodel groen. Het resultaat is hetzelfde in de beide tabellen. Voor zeven elementtypen was dit niet mogelijk, omdat ze geen evenknie hebben in het RCE-standaardbegrotingsmodel (zie verder paragraaf 3.5.5 en paragraaf 5.1.8).

\section{Vervangende rekenregels onderhoudskosten: weegfactoren}

In sommige gevallen was het nodig de rekenregels voor onderhoudskosten van het RCEstandaardbegrotingsmodel groen aan te passen. Dit was aan de orde wanneer de rekenregels informatie vroegen die in de veldinventarisatie om redenen van beschikbare tijd en middelen niet was verzameld. Een voorbeeld is het elementtype laanbomen, waarbij het standaardbegrotingsmodel voor de onderhoudsactie snoeien onderscheid maakt in drie klassen die verschillen in snoeihoogten en aantal takken per boom. De klassen verschillen in kostenfactor. Iets soortgelijks speelt bij een andere onderhoudsactie in het elementtype laanbomen, nl. incidenteel kappen, verwijderen bomen, vellen en stobbe verwijderen. Hier worden verschillende stamdiameters onderscheiden met verschillende kostenfactoren. Snoeihoogte, aantal takken per boom en stamdiameter zijn om redenen van beschikbare tijd en middelen niet opgenomen tijdens de veldinventarisatie.

In gevallen zoals deze zijn de rekenregels aangepast door te werken met generieke weegfactoren. Deze zijn toegevoegd in kolom $\mathrm{F}$ van de beide tabellen. De weegfactoren staan standaard op $100 \%$, wat betekent dat de oorspronkelijke rekenregel van het RCE-standaardbegrotingsmodel gehandhaafd blijft. In kolom $D$ van beide tabellen is in voorkomende gevallen toegelicht waarom en hoe de rekenregels zijn aangepast (Figuur 29).

\section{Activeren of uitschakelen van rekenregels voor de kostenberekening}

Rekenregels kunnen op een aantal manieren zijn uitgeschakeld:

- Door in kolom F de weegfactor op $0 \%$ te stellen. Het berekende bedrag voor de betreffende onderhoudsactie wordt dan $€ 0$.

- Door in kolom H geen aantal of hoeveelheid (stuks, oppervlakte, lengte, ...) in te voeren vanuit de GIS-database. 


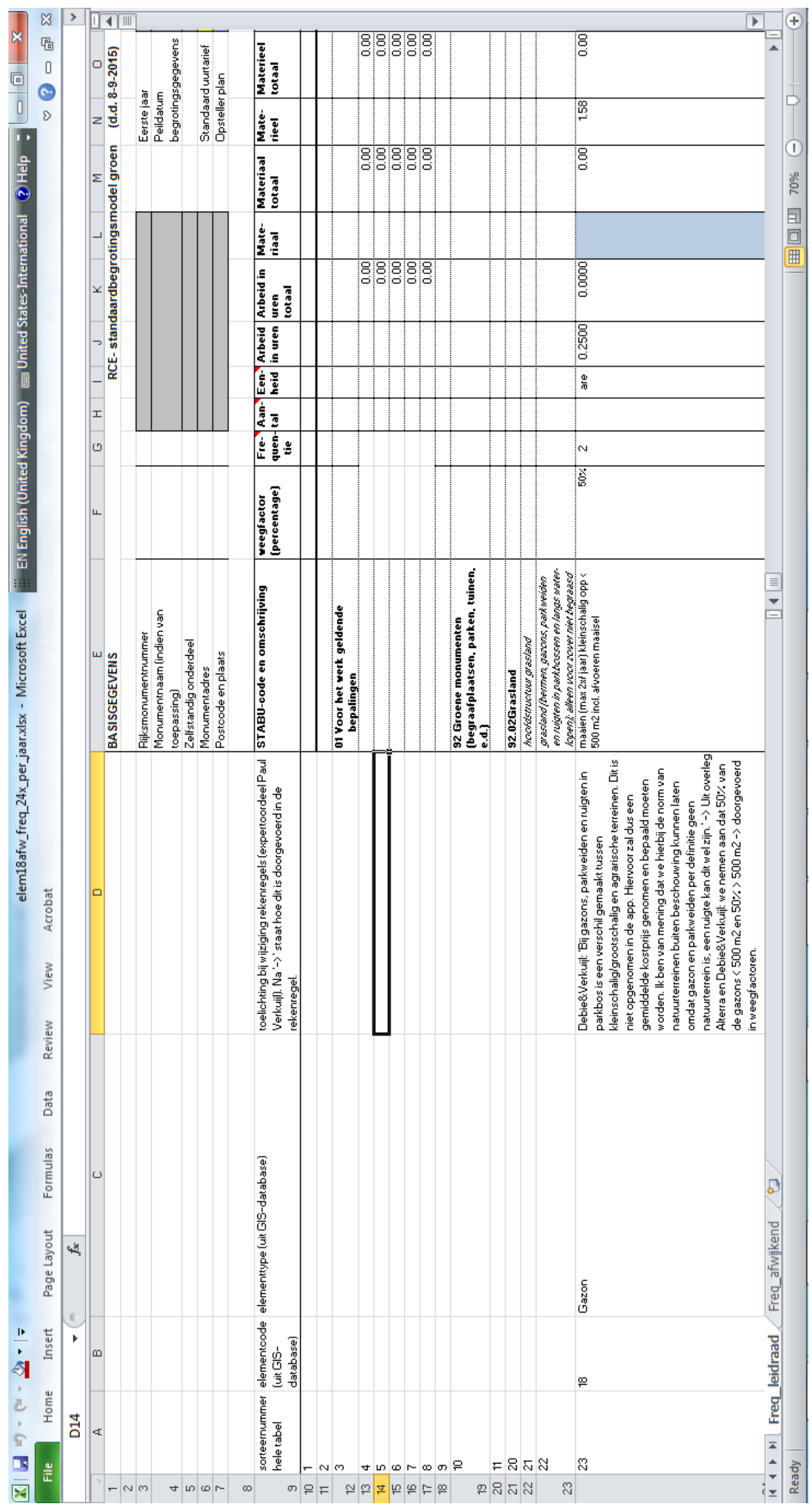

Figuur 29 Detail bovenste deel kostenberekeningstabel Freq_leidraad. 


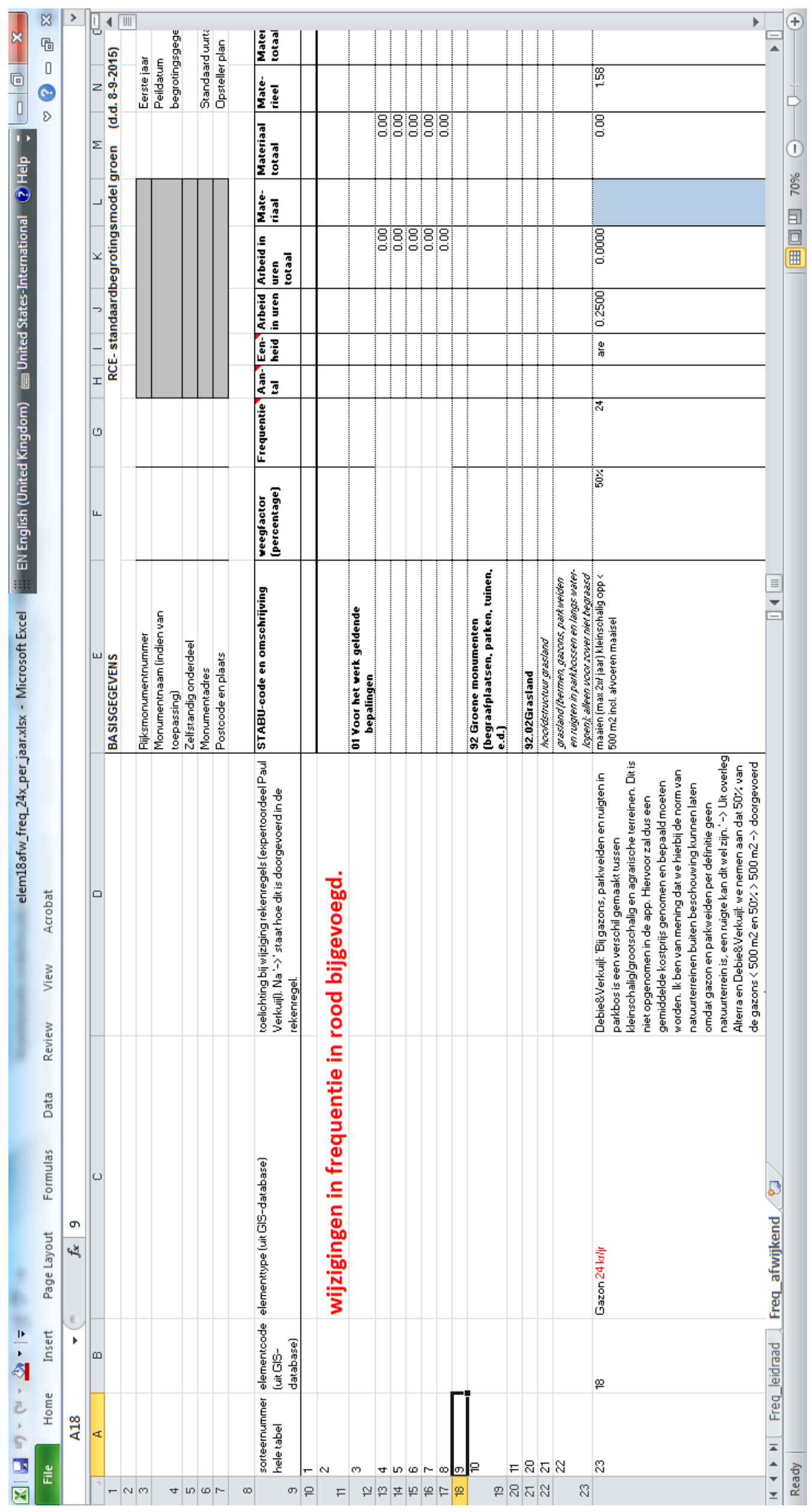

Figuur 30 Detail bovenste deel kostenberekeningstabel Freq_afwijkend. 


\section{Weegfactoren: aannamen m.b.t. inboetfrequenties en plantafstanden}

Voor de berekening van de onderhoudskosten is in het kader van dit onderzoek net als in de Leidraad uitgegaan van daadwerkelijk benodigd onderhoud. Om dit voor een generieke kostenberekening behorende bij een brede inventarisatie als deze hanteerbaar te maken, is gewerkt met aannamen voor omlooptijden (vervangtijden) van bomen en heesters.

- Fruitbomen, leifruit: De omlooptijd bedraagt gemiddeld $50 \mathrm{jr}$. Dit houdt in dat fruitbomen $1 \mathrm{x}$ in de $50 \mathrm{jr}$. vervangen dienen te worden. In de berekening is gerekend met elk jaar 1/50 deel van het totale aantal fruitbomen vervangen.

- Topiaria: De omlooptijd bedraagt gemiddeld $100 \mathrm{jr}$. Dit houdt in dat topiaria om de $100 \mathrm{jr}$. vervangen dienen te worden. In de berekening is gerekend met elk jaar $1 / 100$ deel van het totale aantal topiaria vervangen.

- Hagen, berceaus: Door de grote verscheidenheid in soorten is een omlooptijd lastig te bepalen; we hanteren daarom een gemiddelde van $80 \mathrm{jr}$. De hagen zijn per $\mathrm{m}^{1}$ in de app opgenomen en de inboet gaat per stuk. Gemiddeld staan er per $\mathrm{m}^{1} 5 \mathrm{st}$. haagplanten. Dit houdt in dat er per $\mathrm{m}^{1}$ haag $1 / 80 \times 5$ aantal st. berekend is.

- Heestergroepen: Door de grote verscheidenheid in soorten is een omlooptijd lastig te bepalen, daarom hanteren we gemiddeld $80 \mathrm{jr}$. De heestergroepen zijn per $\mathrm{m}^{2}$ in de app opgenomen en de inboet gaat per stuk. Gemiddeld staan er per $\mathrm{m}^{2} 0,75$ st. planten. Dit houdt in dat er per $\mathrm{m}^{2}$ heestergroepen $1 / 80 \times 0,75$ aantal st. berekend is.

- Heesterborders: Door de grote verscheidenheid in soorten is een omlooptijd lastig te bepalen, daarom hanteren we gemiddeld $50 \mathrm{jr}$. De heesterborders zijn per $\mathrm{m}^{2}$ in de app opgenomen en de inboet gaat per stuk. Gemiddeld staan er per $\mathrm{m}^{2} 1,5 \mathrm{st}$. planten. Dit houdt in dat er per $\mathrm{m}^{2}$ heestergroepen $1 / 50 \times 1,5$ aantal st. berekend is.

- Vaste planten: De gemiddelde omlooptijd van een vaste plant bedraagt $10 \mathrm{jr}$. De vaste plantenborders zijn per $\mathrm{m}^{2}$ in de app opgenomen en de inboet gaat per stuk. Gemiddeld staan er per $\mathrm{m}^{2} 7$ st. vaste planten. Dit houdt in dat er per $\mathrm{m}^{2}$ vaste planten $1 / 10 \times 7$ aantal st. berekend is.

- Rozenperken: De gemiddelde omlooptijd van een rozenstruik bedraagt $20 \mathrm{jr}$. De rozenperken zijn per $\mathrm{m}^{2}$ in de app opgenomen en de inboet gaat per stuk. Gemiddeld staan er per $\mathrm{m}^{2} 3$ st. rozen. Dit houdt in dat er per $\mathrm{m}^{2}$ rozenperken $1 / 20 \times 3$ aantal st. berekend is.

- Parkbosranden: De omlooptijd van een boom in de parkbosrand bedraagt gemiddeld 150 jr. Dit houdt in dat een boom $1 \mathrm{x}$ in de $150 \mathrm{jr}$. vervangen dient te worden. In de berekening is gerekend met elk jaar 1/150 deel van het totale aantal bomen in een parkbosrand vervangen. De parkbosranden zijn per $\mathrm{m}^{1}$ in de app opgenomen en de inboet gaat per stuk. Gemiddeld staan er per $100 \mathrm{~m}^{1} 8 \mathrm{st}$. bomen. Dit houdt in dat er per $\mathrm{m}^{1}$ parkbosrand $1 / 150 \times(8 / 100)$ aantal st. berekend is.

- Laanbomen/boomsingels: In de praktijk worden slechts incidenteel bomen in lanen ingeboet. De laatste jaren zijn de inzichten gewijzigd, omdat individuele inboet geen goede resultaten geeft: nieuwe jonge aanplant in een bestaande laan slaat niet aan door de concurrentie van de omringende oudere bomen. Tegenwoordig worden daarom grotere aaneengesloten delen van een laan vervangen/ingeboet. Dit wordt vaak gedaan aan het eind van de omlooptijd van een betreffende boomsoort (variërend tussen de 100 en 300 jaar). Inboet van grotere laandelen wordt niet beschouwd als sober en doelmatig onderhoud, maar valt onder restauratiewerkzaamheden. Restauraties worden niet vergoed door de Sim. In overleg met de RCE is toch een percentage van inboet lanen opgenomen in de kostenberekening (om jonge, heringeplante lanen bij te kunnen houden en in een beperkt aantal gevallen toch te proberen of inboeten wel werkt. De RCE ziet dat deze post in Sim-plannen toch vaker wordt opgevoerd; wellicht strategisch). Omdat we de stamdiameter bij de veldinventarisatie niet hebben vastgesteld, nemen we aan dat elk van de 6 stamdiameterklassen in gelijke mate vertegenwoordigd is. Voor de omlooptijd van laanbomen hanteren we 200 jaar, de inboetfactor wordt daarmee 1/200 (0,5\%) per jaar. Als omrekenfactor van $\mathrm{m}^{1}$ laanbomenrij naar stuks bomen wordt 0,25 gehanteerd ( 1 boom per $4 \mathrm{~m}$ ). Ten slotte is op advies van de klankbordgroep uitgegaan van een uitvalpercentage van $10 \%$ van de laanbomen. 


\section{Toelichting keuzes m.b.t. indirecte kosten (vgl. paragraaf 3.5.3, in bijzonder Tabel 4)}

In overleg met de RCE zijn de volgende percentages aangehouden, gebaseerd op het RCEstandaardbegrotingsmodel groen:

- Onvoorzien: $5 \%$. Dit is voor zaken als een boom die omwaait als gevolg van een storm.

- Directiekosten: de volgende percentages zijn aangehouden:

- Opstellen instandhoudingsplan: 3\% (maximum volgens Leidraad). Een instandhoudingsplan bevat een Inspectierapport, Werkomschrijving en begroting die bij een Sim-aanvraag vereist zijn.

- Jaarlijkse begeleidingskosten: 6\% (maximum volgens Leidraad). Veel eigenaren werken zonder beheerplan of beheervisie en hebben dus ook geen begeleidingskosten bij de uitvoering van onderhoudswerkzaamheden. Een beheerplan is niet verplicht bij de Sim, maar het gebruik ervan wordt wel door de Rijksdienst geadviseerd en gestimuleerd. Particulieren hebben vaak een tuinbaas in dienst die zijn werk uitvoert op basis van ervaring (dus zonder beheerplan), waardoor de begeleidingskosten vervallen. Ook objecten waarbij vrijwilligers ingezet worden, werken vaak naar eigen inzicht zonder beheerplan.

- Adviseurskosten: $0 \%$ aangehouden. Adviseurskosten spelen een grotere rol in de wereld van het rode erfgoed. Bij het groen erfgoed komen adviseurskosten voor in de vorm van het opstellen van een historisch onderzoek. De kosten van tuinhistorisch onderzoek zijn lastig in een percentage uit te drukken, omdat de kosten in geringe mate afhankelijk zijn van de grootte en onderhoudskosten van een object. Daarnaast komen adviseurskosten voor bij de inzet van boomverzorgers, die in dit onderzoek bij boomonderhoud in de Sim-berekening zijn verwerkt. We nemen aan dat de onderschatting die door het op 0 stellen van de adviseurskosten ontstaat, in voldoende mate wordt gecompenseerd door de post onvoorzien en door de ruime schatting voor de jaarlijkse begeleidingskosten (directiekosten).

- Leges: verwaarloosbaar, $0 \%$ aangehouden. Bij het onderhoud van groen erfgoed is geen vergunning nodig. Alleen bij het aanvragen van een kapvergunning moet een omgevingsvergunning aangevraagd worden, maar dan zullen de leges nooit $1,5 \%$ van het gehele onderhoudsbedrag bedragen.

- Indexeringspercentage: $3 \%$ aangehouden (maximum volgens Leidraad). De verwachting is dat uurlonen (de Sim-norm voor uurloon is laag in verhouding met de praktijk) de komende jaren gaan stijgen door de krappe arbeidsmarkt.

- Btw: $21 \%$, geen btw-teruggave ingesteld.

\section{Berekende kosten zijn op jaarbasis}

De berekende bedragen zijn op jaarbasis; in de tabellen afgeleid van het RCE-standaardbegrotingsmodel groen is bij 'jaar van de werkzaamheden' alleen bij 2017 een 'j' ingevuld om de rekenregel in de kostenberekening te laten meetellen.

Bij laagfrequente onderhoudsacties, zoals het verkuipen van kuipplanten (waar volgens de norm maximaal $1 \times$ per zes jaar als sober en doelmatig is aangehouden), is in kolom $G$ ingevuld: ' 0,167 ' $(=1 / 6)$ (vgl. Figuur 29). 


\section{Bijlage 4 Onderhoudsstaat per categorie groen erfgoed, eigenaar en provincie}

De tabellen in deze bijlage vormen een aanvulling op de in paragraaf 4.1 gepresenteerde overzichten van de onderhoudsstaat per categorie groen erfgoed, per categorie eigenaar, per provincie en per elementtype. In onderstaande tabellen zijn de gegevens over de onderhoudsstaat steeds uitgesplitst naar de prioriteit van de elementtypen (prioriteit 1 of 2). Voor een overzicht van de prioriteit per elementtype wordt verwezen naar Bijlage 2.
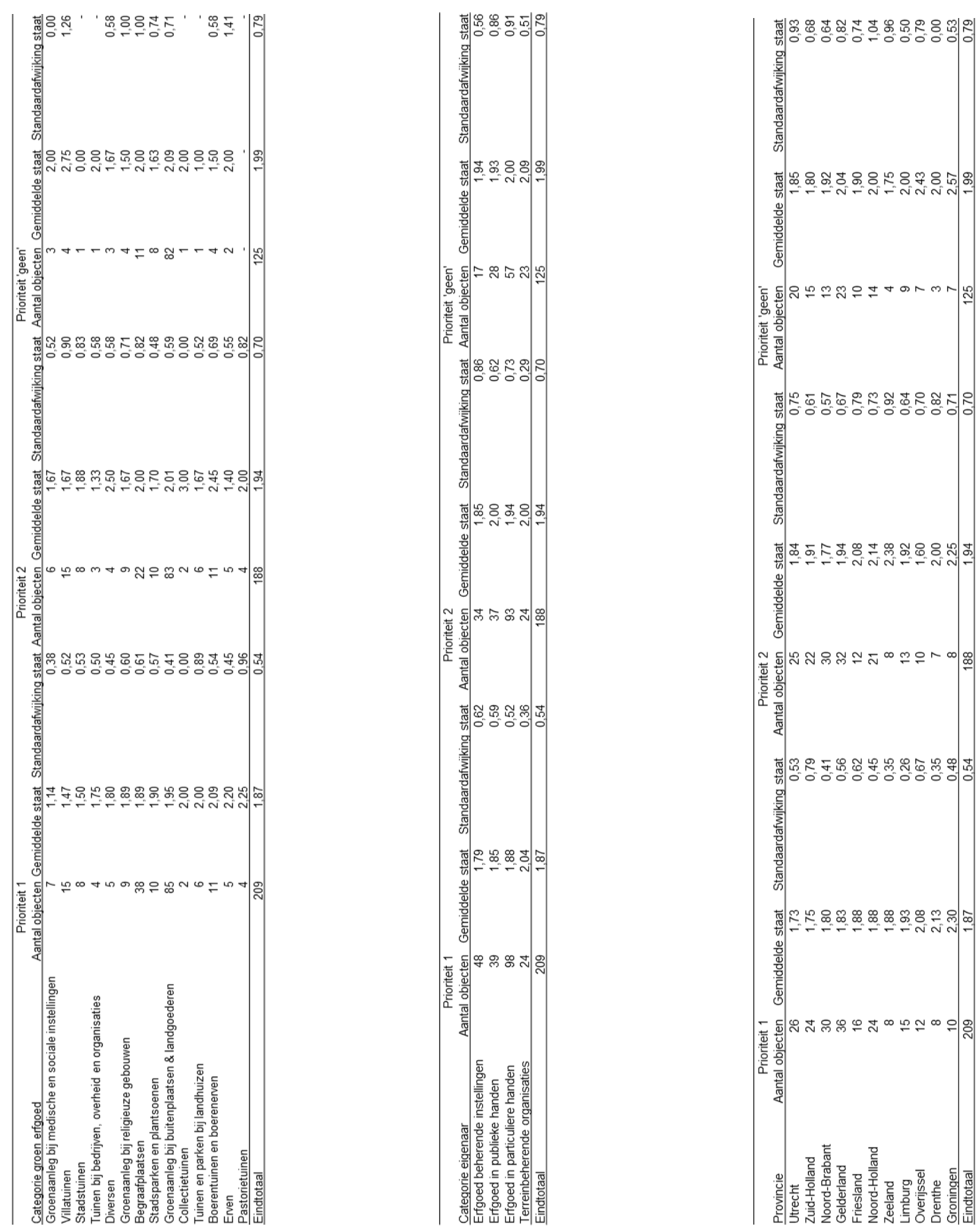


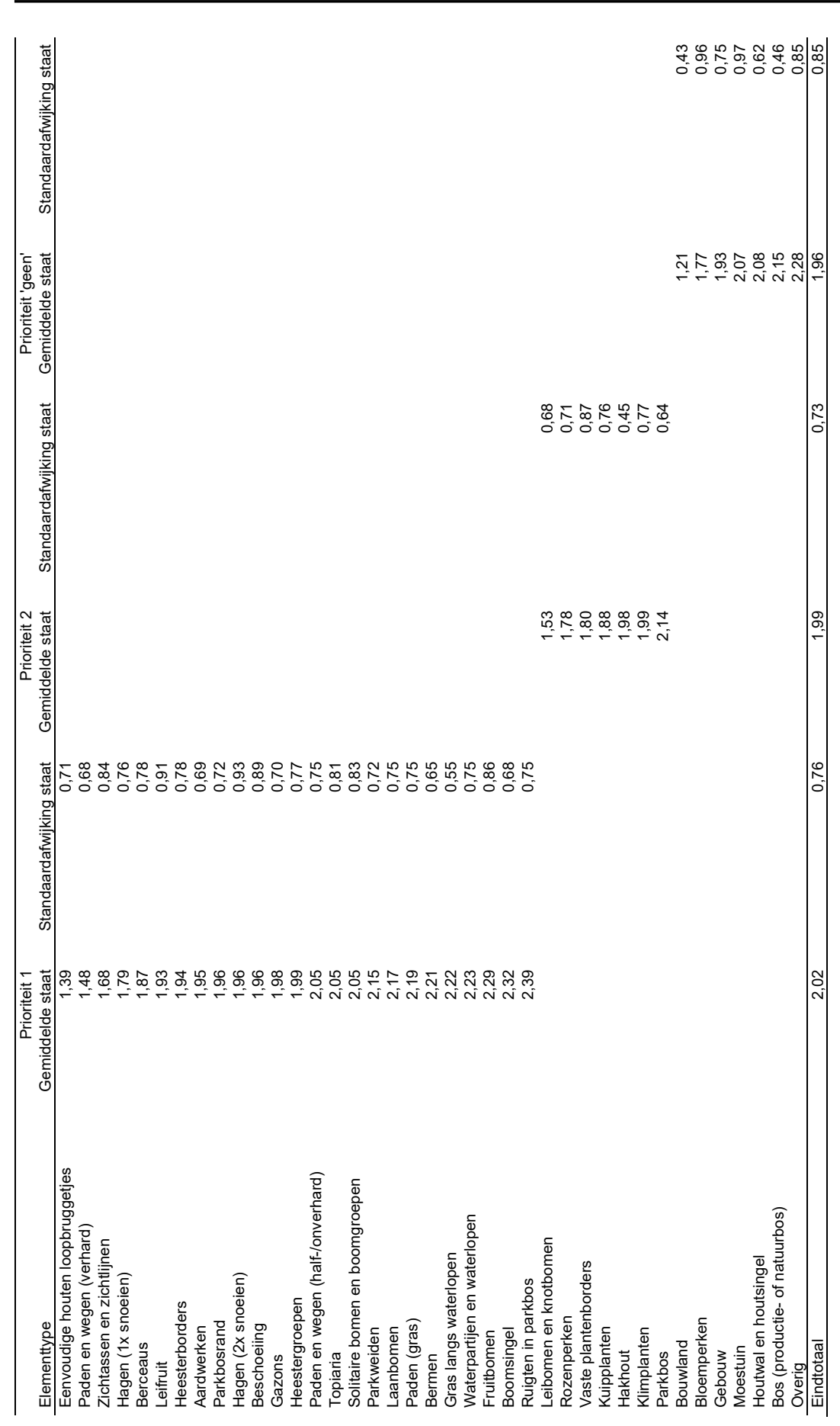




\section{Bijlage 5 Onderhoudskosten naar prioriteit en onderhoudsfrequentie}

De tabellen in deze bijlage vormen een aanvulling op de in paragraaf 5.1 gepresenteerde kostenoverzichten per categorie groen erfgoed, per categorie eigenaar, per provincie en per elementtype. In onderstaande tabellen zijn de kosten steeds uitgesplitst naar de prioriteit van de elementtypen (prioriteit 1 of 2) en naar de frequentie voor sober en doelmatig onderhoud (frequentie volgens Leidraad of daarvan afwijkend). Voor overzichten van de prioriteit en afwijkingen van de onderhoudsfrequenties per elementtype wordt verwezen naar Bijlage 2.
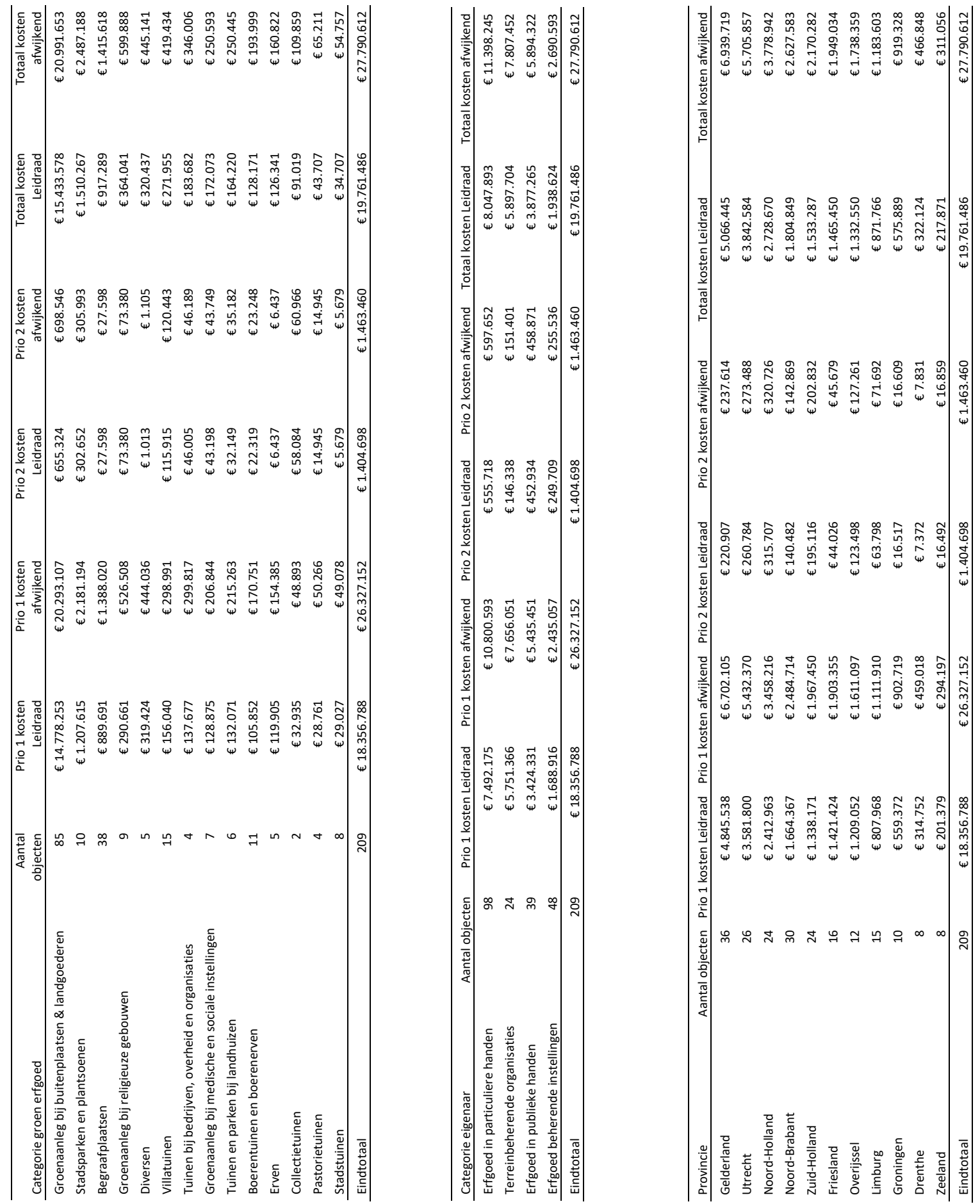


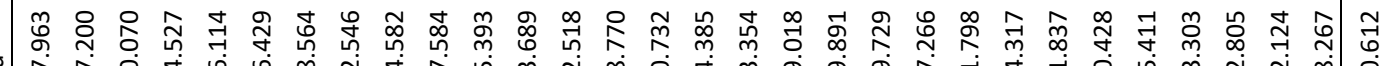

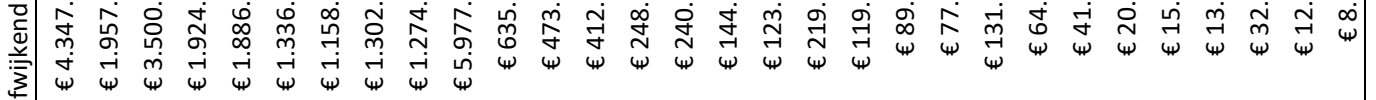

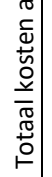

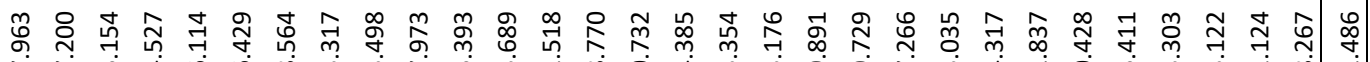

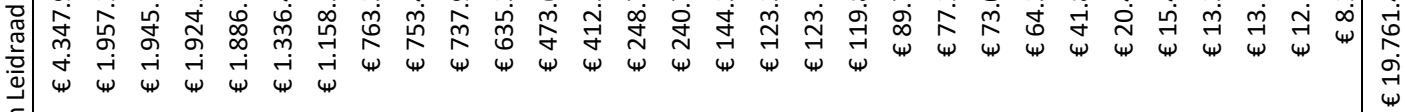

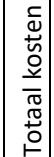

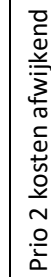

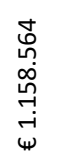

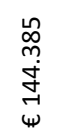

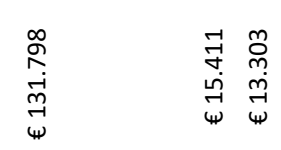

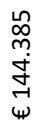

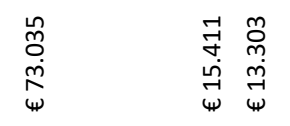

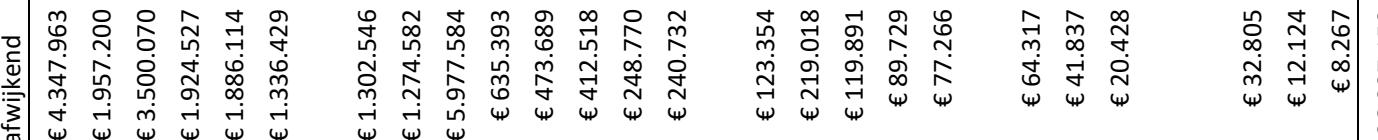

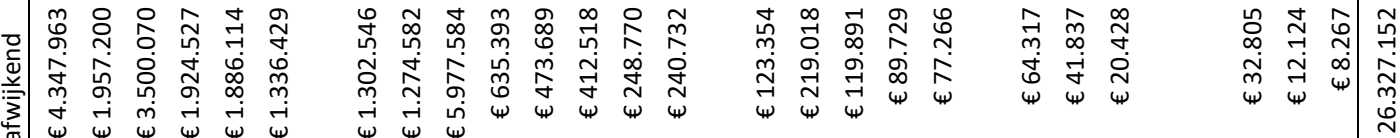

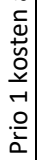

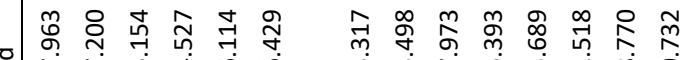

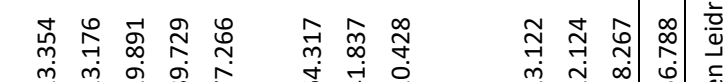

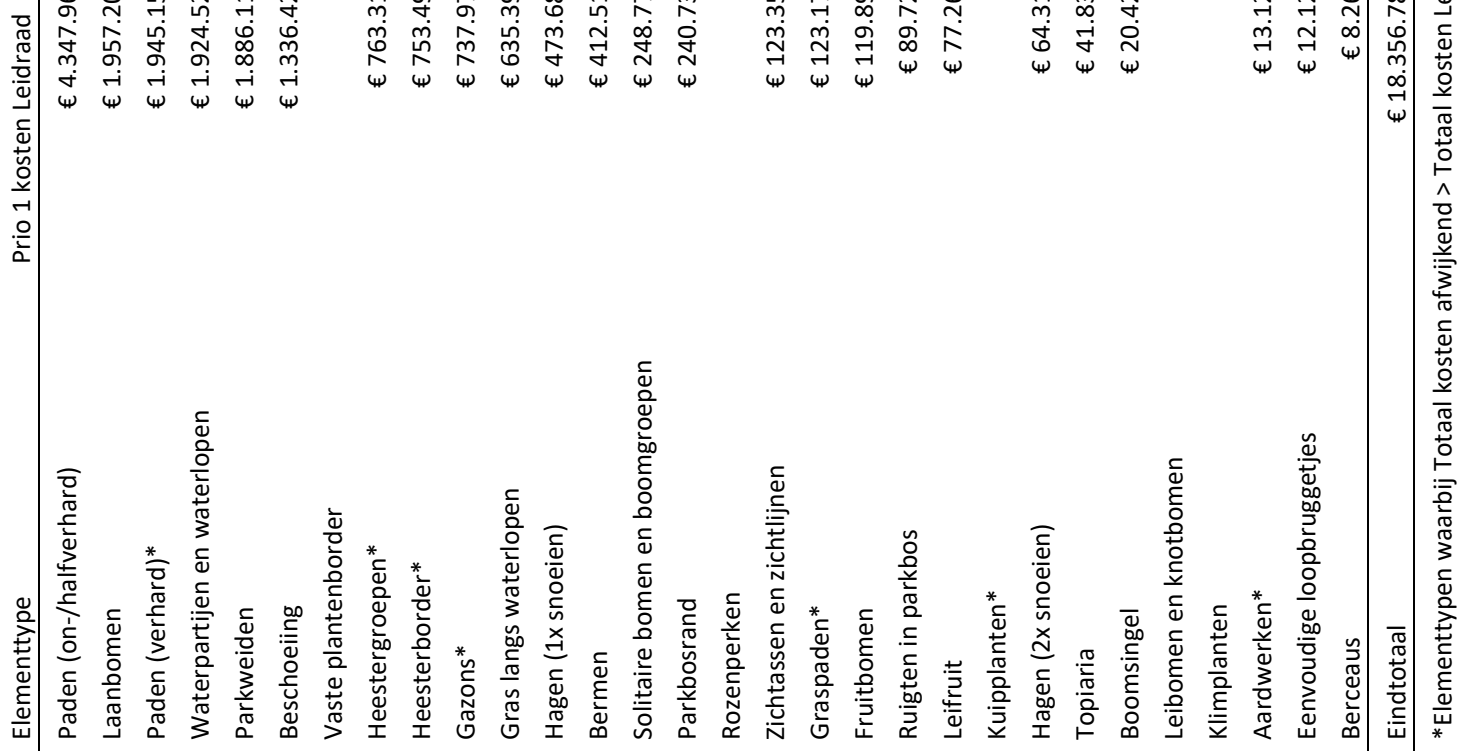




\section{Bijlage 6 Schatting onderhoudskosten elementtypen niet in RCE- standaardbegrotingsmodel}

De kostenberekening is beperkt tot elementen die zijn opgenomen in het RCE-standaardbegrotingsmodel groen (d.d. 8-9-2015). Dat betekent dat voor een aantal elementtypen die wel zijn opgenomen in het beeldkwaliteitsdocument en die in het veldwerk zijn geïnventariseerd op onderhoudsstaat, geen onderhoudskosten zijn berekend. De betreffende elementtypen zijn opgenomen in onderstaande tabel. Om een beeld te krijgen van hun bijdrage aan de totale onderhoudskosten, is een schatting van de onderhoudskosten gemaakt met behulp van SNL (2016) en deskundigenoordeel.

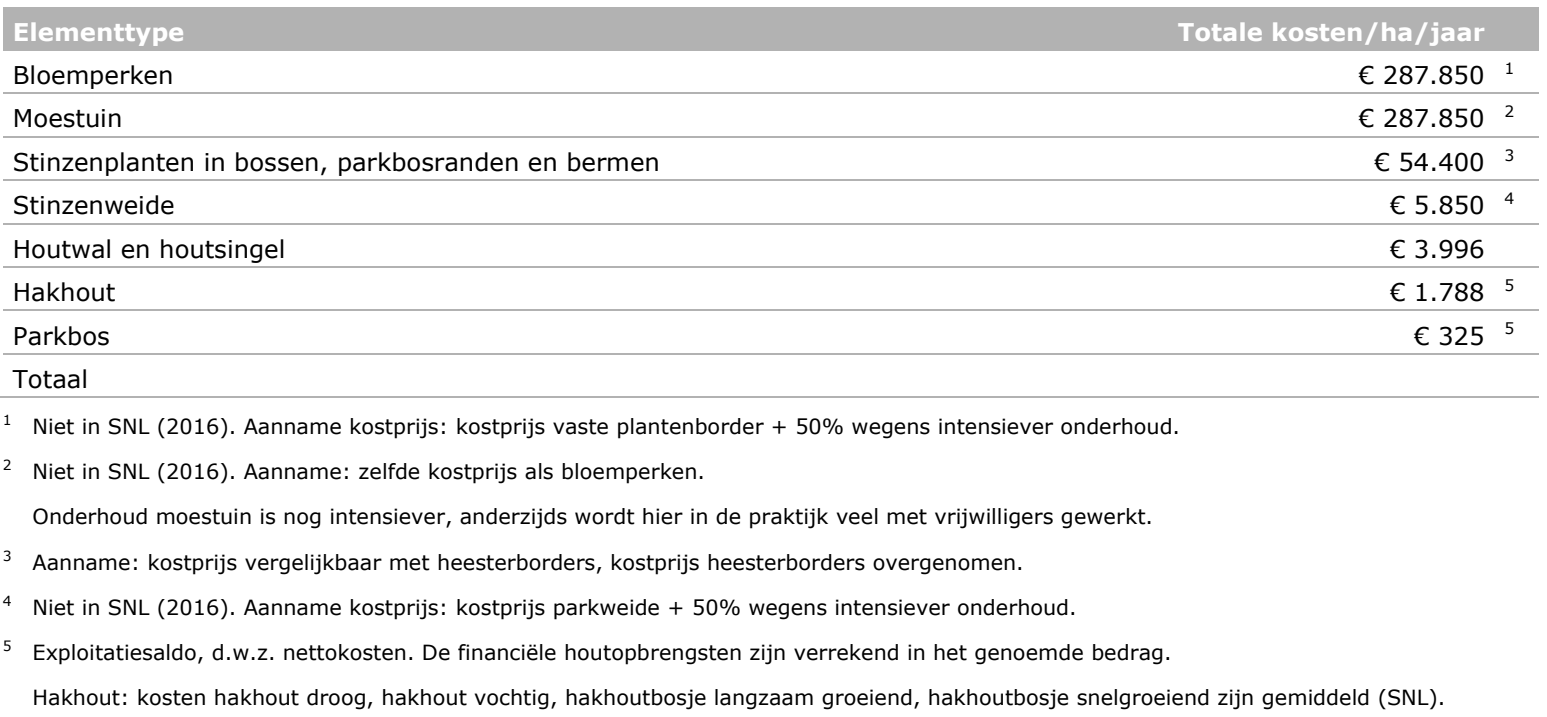




\section{Bijlage 7 Waargenomen afwijkingen van de omschrijving van het rijksmonument}

In aanvulling op paragraaf 6.1 zijn in deze bijlage overzichten opgenomen van de verschillende typen afwijkingen van de omschrijving. De overzichten zijn ingedeeld naar categorie groen erfgoed, categorie eigenaar en provincie.
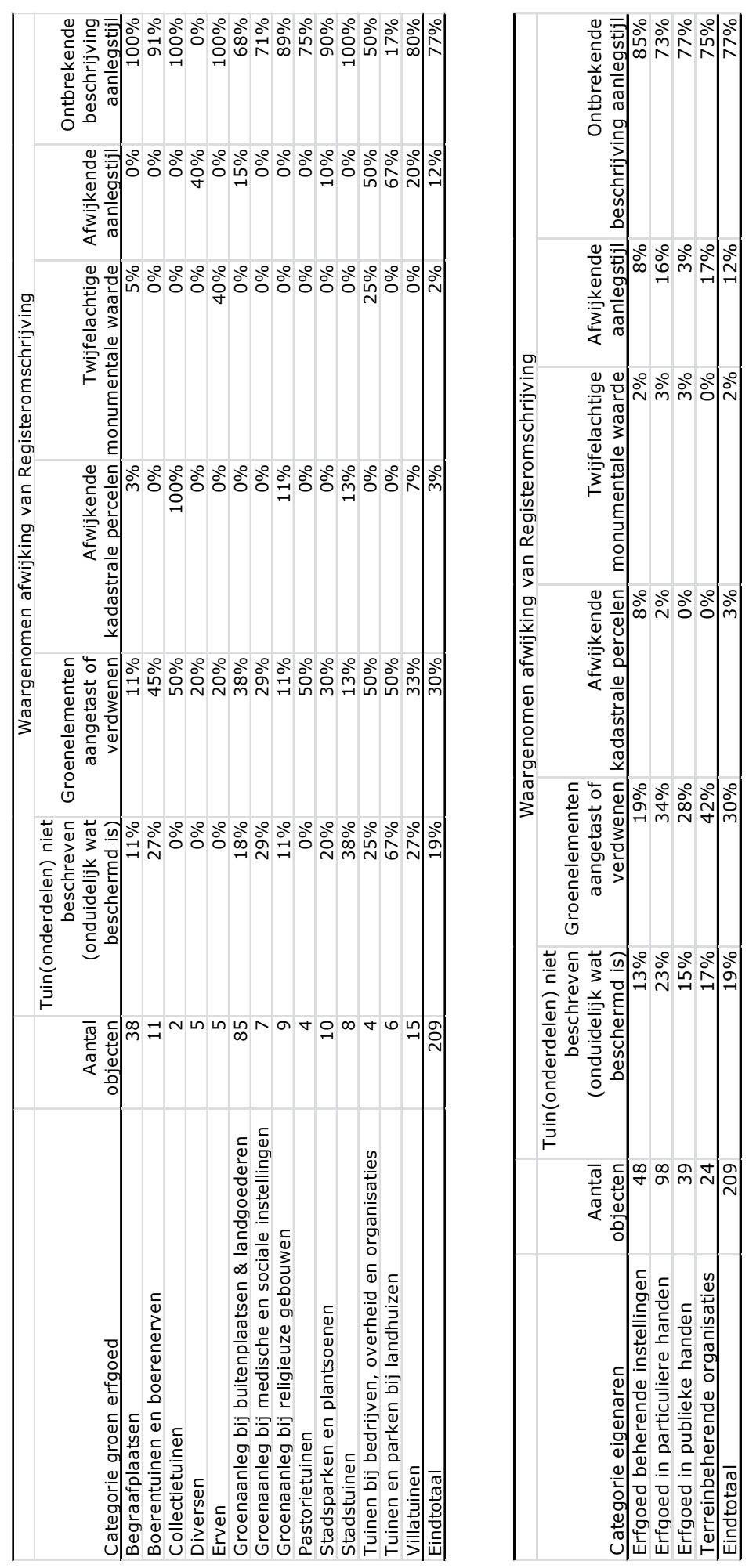


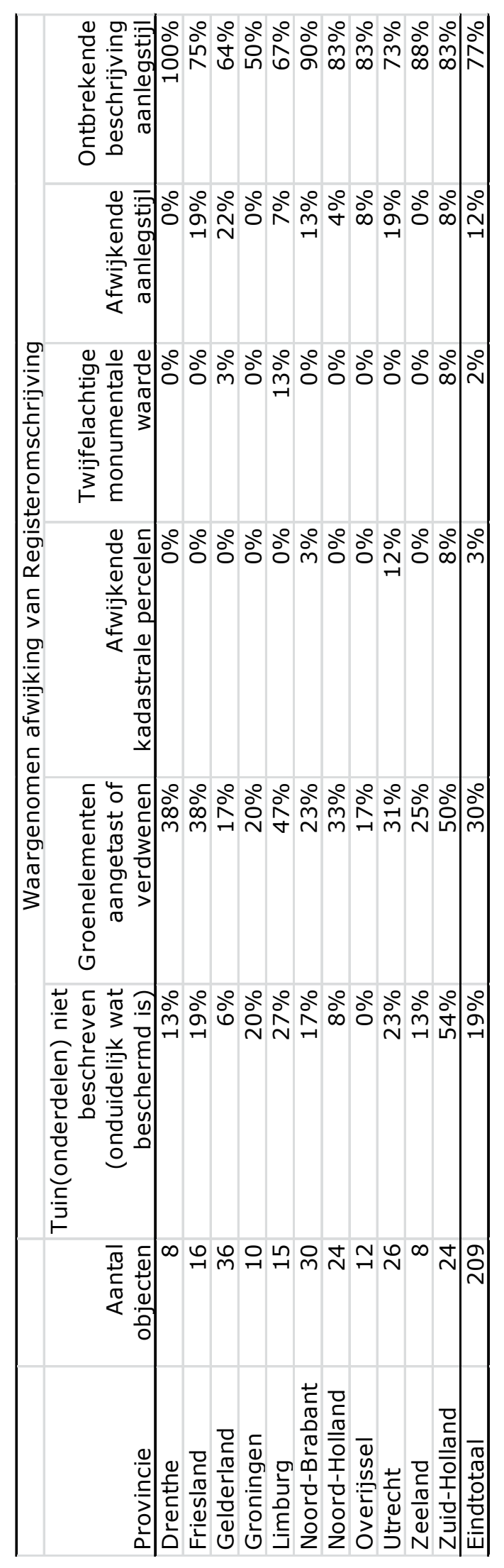


Wageningen Environmental Research Postbus 47

6700 AA Wageningen

T 0317480700

www.wur.nl/environmental-research

Wageningen Environmental Research

Rapport 2773

ISSN 1566-7197
De missie van Wageningen University \& Research is 'To explore the potential of nature to improve the quality of life'. Binnen Wageningen University \& Research bundelen Wageningen University en gespecialiseerde onderzoeksinstituten van Stichting Wageningen Research hun krachten om bij te dragen aan de oplossing van belangrijke vragen in het domein van gezonde voeding en leefomgeving. Met ongeveer 30 vestigingen, 5.000 medewerkers en 10.000 studenten behoort Wageningen University \& Research wereldwijd tot de aansprekende kennisinstellingen binnen haar domein. De integrale benadering van de vraagstukken en de samenwerking tussen verschillende disciplines vormen het hart van de unieke Wageningen aanpak. 



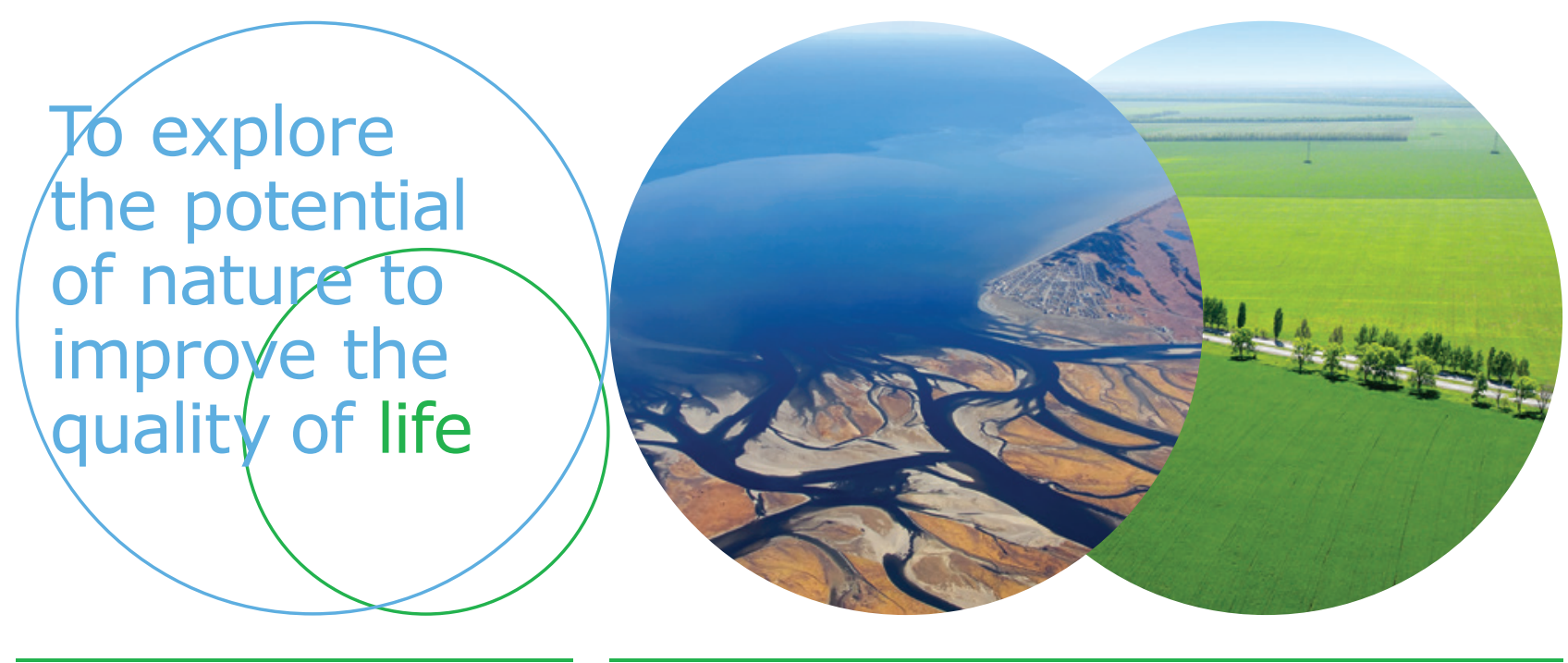

Wageningen Environmental Research Postbus 47

$6700 \mathrm{AB}$ Wageningen

T 317480700

www.wur.nl/environmental-research

Rapport 2773

ISSN 1566-7197
De missie van Wageningen University \& Research is 'To explore the potential of nature to improve the quality of life'. Binnen Wageningen University \& Research bundelen Wageningen University en gespecialiseerde onderzoeksinstituten van Stichting Wageningen Research hun krachten om bij te dragen aan de oplossing van belangrijke vragen in het domein van gezonde voeding en leefomgeving. Met ongeveer 30 vestigingen, 5.000 medewerkers en 10.000 studenten behoort Wageningen University \& Research wereldwijd tot de aansprekende kennisinstellingen binnen haar domein. De integrale benadering van de vraagstukken en de samenwerking tussen verschillende disciplines vormen het hart van de unieke Wageningen aanpak. 